UNIVERSIDADE DE SÃO PAULO

FACULDADE DE EDUCAÇÃO

\title{
A TRANSFERÊNCIA E A AÇÃO EDUCATIVA
}

\author{
DISSERTAÇÃO DE MESTRADO
}

ELISABETE APARECIDA MONTEIRO

SÃO PAULO - 2000 
UNIVERSIDADE DE SÃO PAULO

FACULDADE DE EDUCAÇÃO

\section{A TRANSFERÊNCIA E A AÇÃO EDUCATIVA}

Dissertação apresentada ao Programa de Pós-graduação em Educação, da Faculdade de Educação da Universidade de São Paulo, como requisito parcial à obtenção do título de Mestre em Educação, sob orientação do Prof. Dr. Leandro de Lajonquière. 
BANCA EXAMINADORA

Prof. Dr. Alberto Villani

Prof $^{\mathrm{a}}$. Dr ${ }^{\mathrm{a}}$. Walkíria H. Grant

Prof. Dr. Leandro de Lajonquière

Orientador 


\section{AGRADECIMENTOS}

A Dona Lourdes e ao Sr. Ayres - meus pais - que, com toda a simplicidade de vidas pouco letradas e de muito trabalho, sempre ocuparam a posição de mestres e importantes provedores. Se fui capaz de aprender a lição, terei herdado dois grandes valores: humildade e honestidade.

A todas as ilustres mentes sem as quais não existiria esta reflexão. Especialmente a Freud, pela inteligência, paciência e coragem com que conduziu seu trabalho. Meu "obrigada" pelo legado que deixou à civilização.

A todos os mestres da minha vida que, alvos da minha transferência, foram os inspiradores na escolha do tema.

Ao Prof. Dr. Leandro de Lajonquière, orientador deste trabalho, pela clareza, sabedoria e disponibilidade imprescindíveis, pela paciência incomum.

À Profa. Dra. Maria Cristina M. Kupfer e ao Prof. Dr. Alberto Vilani, pela leitura minuciosa e preciosas observações no exame de qualificação.

Aos amigos e colegas que pacientemente leram e, de diferentes maneiras, contribuíram para o avanço de minhas reflexões: Cynthia, Renata, Rosana, Sílvia e Tácito.

A Joana, pela valiosa revisão.

À FAPESP, pela viabilização desta pesquisa. 
Gostaria de registrar aqui a comemoração dos cem anos da primeira edição de $A$ Interpretação de Sonhos, sem dúvida alguma, marco importantíssimo da obra freudiana. Freud sonhou e "sonhou". Muitos, como eu, permanecem embalados pelos seus sonhos.

"Posso apenas manifestar a esperança de que os leitores deste livro se coloquem em minha difícil posição e me tratem com indulgência, e, além disso, que qualquer um que encontre alguma espécie de referência a si próprio em meus sonhos se disponha a conceder-me o direito à liberdade de pensamento - ao menos em minha vida onírica, se não em qualquer outra área."

(Sigmund Freud, Prefácio à Primeira Edição de A Interpretação de Sonhos - 1900) 


\section{PRIMEIRO CAPÍTULO}

SOBRE A PRETENSA RELAÇÃO PROFESSOR-ALUNO.

A Dita Pré-História da "Relação Professor-Aluno".

A Relação ou Interação Professor-Aluno segundo a Pedagogia de Hoje.........................16

A Ilusória Relação Adequada da Pedagogia Atual.........................................................21

A Autoridade e o Dispositivo da Ação Educativa............................................................23

\section{SEGUNDO CAPÍTULO}

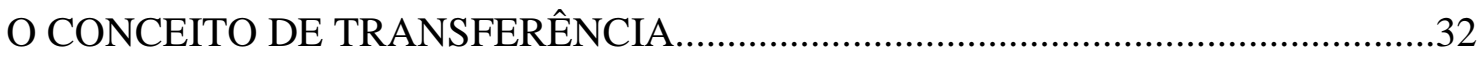

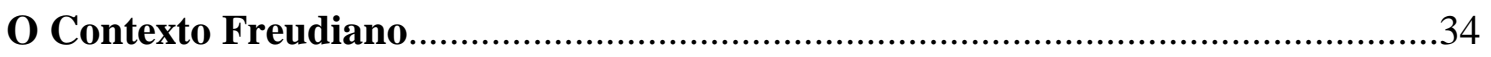

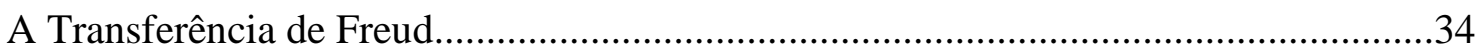

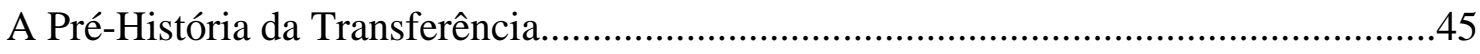

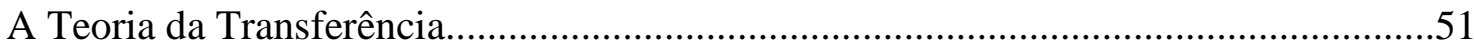

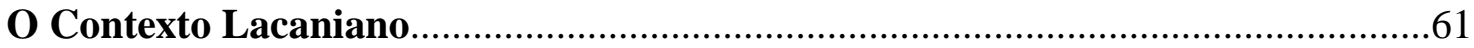

A Formação Lingüística do Inconsciente - A Constituição do Sujeito...........................62

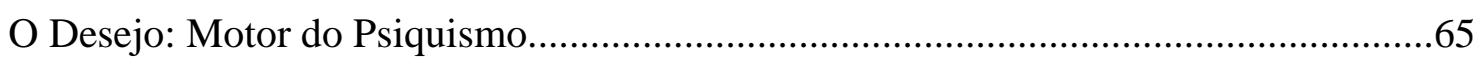

O Conceito de Transferência em Lacan....................................................................68 


\section{TERCEIRO CAPÍTULO}

A PSICANÁLISE, A TRANSFERÊNCIA E A IMPOSSIBILIDADE DE RELAÇÃO..............76

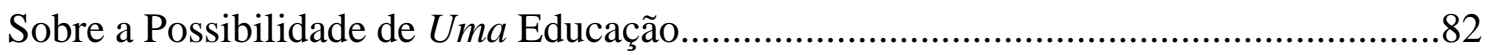

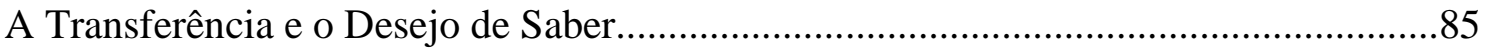

A Transferência e a Impossibilidade da Educação..........................................................92

As Tentativas de se aplicar o Conceito de Transferência à Ação Educativa....................98

A "Utilidade” do Saber Psicanalítico na Educação..........................................................102

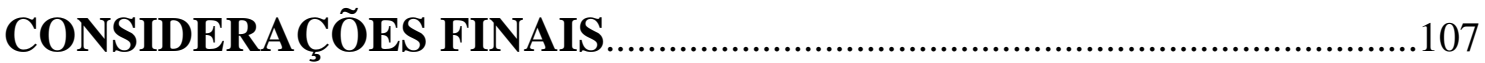

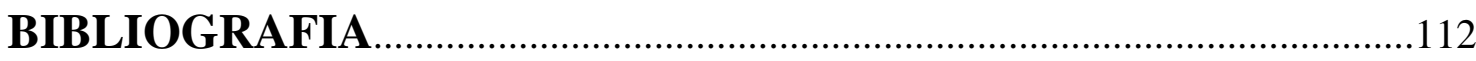




\section{RESUMO}

A discussão que emerge da Psicanálise acerca da impossibilidade de educação aponta para os limites existentes na ação educativa, permitindo-nos refletir, através do vínculo com a noção de transferência, sobre o que se convencionou chamar de "relação professor-aluno". Os educadores nem sempre percebem que a educação não se limita à realidade externa, uma vez que os personagens dessa suposta relação estão mergulhados na realidade transferencial.

Compreendemos a pretensa relação professor-aluno como o núcleo onde se desenvolve a educação propriamente dita. No entanto, aquilo que a Pedagogia atual vislumbra como previsão e controle dos efeitos dessa "relação", a saber, o domínio do conhecimento científico sobre o desenvolvimento das capacidades maturacionais e o ajuste da prática do educador à realidade psicológica de cada aluno, opõe-se ao caráter imprevisível inerente à ação educativa.

Uma vez submetidos às "leis" do inconsciente, os efeitos do encontro entre professor e aluno estão além de qualquer previsão e controle.

O que nos deve interessar, então, é a compreensão da origem desses efeitos. E é isso que o conceito de transferência vem esclarecer. 


\section{INTRODUÇÃO}

Os espaços educacionais andam povoados de preocupações. Fracasso escolar, indisciplina, evasão, depredação, falta de motivação, entre outros fatores, compõem um fantasma no imaginário pedagógico. Bem, se algo vai mal, pensa-se, é porque falta uma adequação do ensino àquilo que a ciência, as teorias psicológicas do desenvolvimento dizem sobre como se processa a educação. Segundo a Pedagogia atual, os desvios nos objetivos educacionais estariam sob o controle do educador à medida que este estivesse munido dos saberes e adequasse sua prática à realidade psicológica de cada aluno em particular. Em suma, o conhecimento sobre o desenvolvimento das capacidades maturacionais permitiria ao professor uma relação mais adequada, que equivaleria ao controle dos efeitos causados pelo encontro professor-aluno e, portanto, ao domínio sobre os desvios que preocupam os pedagogos.

A pretendida prática educativa, cientificamente justificada, tem gerado uma permanente dúvida, às vezes certezas não menos perigosas, sobre a posição do educador. Enquanto a Pedagogia se (pre)ocupa com o devido ajuste entre conhecidos fatores (estímulos) externos e conhecidas capacidades internas, mesmo que não deliberadamente, ela tem tornado a ação educativa um fato de difícil acontecimento. Se ao professor cabe tornar sua prática adequada à realidade cognitiva e afetiva de cada aluno, enquanto procura a posição adequada a cada "relação", do ponto de vista da Psicanálise, fica em suspenso sua verdadeira posição de sujeito suposto saber.

Quando se pensa numa "verdadeira ação educativa" como o perfeito ajuste entre fatores externos e fatores internos, pensa-se, conseqüentemente, na existência de métodos infalíveis. Mais do que isso, parte-se da concepção de indivíduo segundo a qual as possibilidades de sua constituição estão dadas, apenas esperando pelo estímulo certo para eclodir.

A leitura psicanalítica - o estudo do inconsciente - conduz-nos a uma compreensão distinta sobre a constituição dos indivíduos, e nos indica, através da noção de transferência, a irredutibilidade e a imprevisibilidade do resultado do encontro entre os mesmos. Para essa teoria, o sujeito acha-se em permanente formação, em constante 
processo inconcluso de vir a ser. $\mathrm{Na}$ "relação" com o outro ele está se constituindo, assim como esse outro.

O presente estudo pretende mostrar que, para além dos venerados métodos e controles da Pedagogia, é a transferência presente na ação educativa (e nas "relações" entre as pessoas, de modo geral) que permite à educação realmente acontecer, ao mesmo tempo que impossibilita a pretensa relação professor-aluno da Pedagogia atual.

Sabemos que a questão da "relação professor-aluno" é, atualmente, uma das grandes polêmicas nos meios educacionais. Também sabemos que a relação de hoje se pretende mais psicologicamente "adequada" que as que já existiram na história da Educação. É sobre estes (questionáveis) pressupostos que, com o auxílio da leitura dos Parâmetros Curriculares Nacionais, propomos debater no primeiro capítulo deste trabalho.

No segundo capítulo, uma pesquisa sobre o desenvolvimento da noção de transferência, desde antes da sua conceituação até as contribuições mais recentes (de Lacan), vem permitir uma exposição mais clara sobre o conceito, a fim de evitar que se pense, equivocadamente, na possibilidade de uma transposição para a prática educativa sob forma, por exemplo, de "modelos de relação" ou "modelos transferenciais" que facilitem o processo educativo.

Quando nos perguntamos pelas contribuições da Psicanálise à Educação, imediatamente surge a afirmativa freudiana sobre a impossibilidade de educar (junto com outros dois ofícios: governar e curar). Se à primeira vista tal afirmativa nos parece pessimista, ao procurarmos compreendê-la damo-nos conta da extensão do que nos é colocado. A noção de transferência é uma das vias que nos leva a reconhecer a impossibilidade de existir uma ciência positiva da Educação. Essa complexa realidade procuramos abordar mais claramente no terceiro capítulo. 


\section{PRIMEIRO CAPÍTULO}

\section{SOBRE A PRETENSA RELAÇÃO PROFESSOR-ALUNO}

"Para alcançar a verdade é preciso, uma vez na vida, desfazermo-nos de todas as opiniões que recebemos $e$ reconstruir de novo, e desde os fundamentos, todos os sistemas dos nossos conhecimentos."

(René Descartes, 1641) 


\section{SOBRE A PRETENSA RELAÇÃO PROFESSOR-ALUNO}

Certamente não se pode comparar a educação de outrora com a que se desenvolve nas escolas hoje. A diferença se manifesta em vários aspectos do cotidiano escolar e, evidentemente, na ação educativa. Podemos dizer que, atualmente, importantes preocupações rondam as práticas educacionais. Assim, com freqüência encontramos publicações de trabalhos que, normalmente apoiados em teorias científicas, em especial na Psicologia do Desenvolvimento, se propõem discutir e superar os problemas pelos quais, se diz, a educação está passando. Que erro se procura não repetir? O que leva uma legião de educadores a acreditar na inquestionável racionalidade do saber científico para sustentar suas práticas, e assim, distantes de um passado obscuro, pretenderem se tornar, até certo ponto, imunes aos problemas de aprendizagem, à indisciplina, enfim, a tudo que não corresponda às previsões dos projetos pedagógicos?

Devemos apreender, do discurso atual da Pedagogia, que neste trabalho é representado pelos textos que compõem os Parâmetros Curriculares Nacionais (PCNs), o que se recusa da educação que antecede a dos nossos tempos, quais as inadequações da prática pedagógica que hoje se supõem superadas, ou prestes a ser. Assim, procuramos explicitar, rapidamente, a leitura retroativa da transformação da educação à luz dos PCNs que nos falam sobre o que seria uma educação indesejável; depois, trataremos do modelo de prática pedagógica que hoje se propõe. Deixemos claro que não está sendo colocada em questão a pertinência dos comentários contidos nos PCNs sobre as idéias pedagógicas passadas. Estamos, sim, tomando como material de estudo o discurso da Pedagogia atual sobre sua própria história.

Nesse contexto, cabe-nos enfocar a questão da assim chamada relação professoraluno no interior dos modelos educacionais supostamente superados e do modelo vigente. Em uma palavra, para compreendermos a concepção de "relação" professoraluno que hoje se apregoa, buscaremos identificar o que se rejeita, o que se considera indesejável na história dessa "relação" educativa. 


\section{A Dita Pré-História da "Relação Professor-Aluno"}

Parece haver um consenso entre os educadores da atualidade quanto ao chamado ensino tradicional : "Aos professores cabia a transmissão de conhecimentos acumulados pela humanidade, por meio de aulas expositivas, e aos alunos, a absorção das informações. (...) A qualidade do curso era definida pela quantidade de conteúdos trabalhados. O principal recurso de estudo e avaliação era o questionário, ao qual os alunos deveriam responder detendo-se nas idéias apresentadas em aula ou no livro-texto escolhido pelo professor." A leitura que hoje se faz da cena educativa no ensino tradicional aponta no sentido de se pensar que a posição do aluno era secundária, seu papel, passivo, imaturo, em contraposição ao professor que ocupava uma posição importante e centralizadora. A crítica recai sobre a dita autoridade do educador, pois, pensa-se que, ao deter o poder decisório quanto à metodologia, conteúdo, avaliação, forma de interação na aula, enfim, ao centralizar as decisões, o professor estaria demarcando uma posição acentuadamente autoritária. Em linhas gerais, o ensino tradicional passou a ser sinônimo de tudo o que, na prática educacional, é indesejável, autoritário, obsoleto, pertencente a um passado equivocado e desumano. E, apesar de ser considerado ultrapassado, o ensino tradicional nunca deixou de fazer parte do quadro educativo, conservando-se nas práticas de alguns professores que se mantêm, claramente, no lugar da autoridade em sala de aula.

O princípio do ensino dito tradicional era que a realização plena do aluno, enquanto pessoa, se daria através do saber, do conhecimento, portanto, valorizava o ensino humanístico, a cultura geral, o contato com as grandes realizações da humanidade. O esforço era a via de tal realização. Esse fato é interpretado, atualmente, segundo os PCNs, como ultra-valorização do conteúdo, do conhecimento, em detrimento do processo de aprendizagem: "Por muito tempo a pedagogia valorizou o que deveria ser ensinado, supondo que, como decorrência, estaria valorizando o conhecimento. $\mathrm{O}$ ensino, então, ganhou autonomia em relação à aprendizagem, criou seus próprios métodos e o processo de aprendizagem ficou relegado a segundo plano."2

\footnotetext{
${ }^{1}$ BRASIL. Secretaria de Educação Fundamental. Parâmetros Curriculares Nacionais: Ciências Naturais, Brasília, MEC/SEF, 1997, p. 19.

${ }^{2}$ BRASIL. Secretaria de Educação Fundamental. Parâmetros Curriculares Nacionais: Terceiro e Quarto Ciclos do Ensino Fundamental: Introdução aos Parâmetros Curriculares Nacionais, Brasília, MEC/SEF, 1998, p. 71.
} 
Por se tratar de um modelo não mais assumido pelos educadores, sob o registro de ensino tradicional se dizem muitas coisas, o que torna a sua definição bastante plástica e sua delimitação histórica, pouco definida. É possível incluir, sob essa nomenclatura, desde a (muito retrógrada) pedagogia dos castigos corporais até qualquer outra atitude do professor que vise à aplicação, mesmo mais moderada, das sanções disciplinares, dos processos de retenção, da memorização, do esforço.

Dessa maneira, a contestação desse modelo de "relação" educativa não é recente. Já no século XVIII, um primeiro marco do repúdio ao tratamento dispensado à criança encontra-se no trabalho de Jean-Jacques Rousseau. Segundo esse filósofo, o homem é essencialmente bom, assim como a natureza em geral, e se degenera nas mãos do próprio homem: "Para não correr atrás de quimeras, não esqueçamos o que convém à nossa condição. A humanidade tem seu lugar na ordem das coisas; a infância tem o seu na ordem da vida humana; é preciso considerar o homem no homem e a criança na criança. Assinalar a cada um seu lugar e nele fixá-lo, ordenar as paixões humanas segundo a constituição do homem é tudo o que podemos fazer para o seu bem-estar. $\mathrm{O}$ resto depende de causas estranhas a nós e que não estão em nosso poder."3 A criança deve ser criada à margem da sociedade, sem a intervenção de qualquer adulto e tendo apenas a natureza como ajuda: "Quem sabe quantas crianças morrem vítimas da extravagante sabedoria de um pai ou de um mestre?"4 Diante disso, o educador deve apagar-se ou, no máximo, promover a manifestação da natureza infantil: "Amai a infância, favorecei seus jogos, seus prazeres, seu amável instinto. Quem de vós não se sentiu saudoso, às vezes, dessa idade em que o riso está sempre nos lábios e a alma sempre em paz?"5

Podemos considerar as contribuições de Rousseau, assim como as de alguns de seus contemporâneos, como uma primeira "quebra" na história do conceito de educação. Contra uma educação que, ao ignorar seus efeitos, se apoiava no princípio do "adestramento" e na submissão do homem aos valores tradicionais, esses pensadores introduzem a dúvida sobre o fazer pedagógico, à medida que passam a (pre)ocupar-se com a dimensão psicológica da criança. Tais proposições repercutem ainda hoje na reflexão sobre a ação educativa, sobre a necessidade da intervenção do adulto no desenvolvimento das capacidades naturais da criança: (...) "sua crença na constância da

\footnotetext{
${ }^{3}$ Rousseau, Jean-Jacques. Emílio ou da Educação. São Paulo, Difel, 1968, p. 62.

${ }^{4}$ Idem, p. 60.

${ }^{5}$ Idem, p. 61.
} 
evolução psíquica era mesmo tão grande que lhe inspirou a famosa fórmula da educação negativa ou da inutilidade da intervenção do professor."6

Num período posterior, mais precisamente no início do século $\mathrm{XX}$, procurando acompanhar o rápido avanço do conhecimento científico, no furor por idéias e técnicas mais "eficientes", surge a Escola Nova. No dizer dos PCNs: "Essa tendência deslocou o eixo da questão pedagógica, dos aspectos puramente lógicos para aspectos psicológicos, valorizando a participação ativa do aluno no processo de aprendizagem." A supremacia dos "aspectos psicológicos" fez a idéia de aluno ser substituída pela idéia de criança, isto é, a atividade escolar deveria estar voltada para a existência, para os interesses e necessidades da criança, adequando-se, portanto, à psicologia infantil. E, a partir do que se convencionou chamar de métodos ativos, o aluno (criança) deixa de se posicionar de forma passiva, como supostamente ocorria no ensino tradicional.

O distanciamento entre o mundo da criança e o mundo do adulto, a crença em que o interesse pelo conhecimento é natural e espontâneo, sendo desnecessários os modelos educacionais, tiram o professor da função de mediador, passando a ser sua posição absolutamente secundária. De acordo com as proposições da Escola Nova, caberia ao adulto aprender com o mundo da criança, deixando-a livre e observando-a. É o que podemos concluir da descrição das propostas do Escolanovismo para o ensino de Ciências, segundo os PCNs: "O objetivo fundamental do ensino de Ciências passou a ser o de dar condições para o aluno identificar problemas a partir de observações sobre um fato, levantar hipóteses, testá-las, refutá-las e abandoná-las quando fosse o caso, trabalhando de forma a tirar conclusões sozinho. O aluno deveria ser capaz de "redescobrir" o já conhecido pela ciência..."

No movimento Escolanovista, portanto, retorna a pergunta sobre os atributos psicológicos das crianças e os efeitos nocivos do ensino tradicional, que teve sua origem no século XVIII. Então, é proposto um modelo de "relacionamento" que esteja adequado à natureza da criança, conforme à psicologia infantil, o que poderíamos chamar de uma "relação científica" (pois o avanço científico da época deveria entrar pelos portões da escola) entre professor e aluno. Por outro lado, é importante notar que, apesar de esse modelo educacional introduzir a questão da "relação professor-aluno",

\footnotetext{
${ }^{6}$ Piaget, Jean. Psicologia e Pedagogia. Rio de Janeiro, Ed. Forence Universitária, 1998, p. 145.

${ }^{7}$ BRASIL. Secretaria de Educação Fundamental. Parâmetros Curriculares Nacionais: Ciências Naturais. Op. cit., pp. 19-20.

${ }^{8}$ BRASIL. Secretaria de Educação Fundamental. Parâmetros Curriculares Nacionais: Terceiro e Quarto Ciclos do Ensino Fundamental: Introdução aos Parâmetros Curriculares Nacionais. Op. cit., 1998, p. 20 (grifo nosso).
} 
pensa-se paradoxalmente que, para se "relacionar" com o aluno (criança), o professor deve deixar a relação (apagar-se), dada a sua intervenção inútil e perniciosa diante da natureza da criança.

Em resumo, a concepção da natureza infantil, a crença no desenvolvimento natural, inauguradas no século XVIII, são praticadas sem nenhuma hesitação nas propostas trazidas pela Escola Nova. Contra uma educação considerada retrógrada, em que o educador era o centro do processo, a Escola Nova converteu este destaque, delegando-o à figura do aluno. Esses dois momentos da história da Educação produziram importantes efeitos na própria concepção de educação e, conseqüentemente, no tratamento dispensado à questão da "relação" professor-aluno.

\section{A Relação ou Interação Professor-Aluno segundo a Pedagogia de Hoje}

Retomando nossa pergunta inicial sobre o que se rejeita hoje, como algo indesejável, na história da Educação, identificamos a resposta no atual discurso da Pedagogia: o autoritarismo do professor e a valorização do conteúdo em detrimento da aprendizagem são atribuídos ao ensino tradicional. Como contraponto, a postura espontaneísta, a criança deixada livre para o "desabrochar" constitutivo do conhecimento, sem nenhuma intervenção do professor, caracterizam a Escola Nova.

"O conhecimento não é algo fora do indivíduo, a ser adquirido por meio da cópia do real, tampouco algo que o indivíduo constrói independentemente da realidade exterior, dos demais indivíduos e de suas próprias capacidades pessoais. É, antes de mais nada, uma construção histórica e social, na qual interferem fatores de ordem

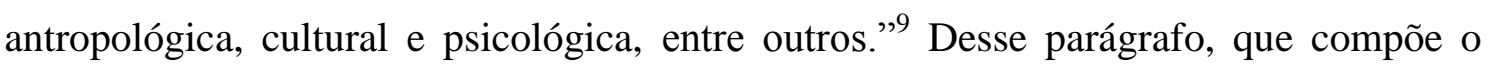
documento oficial do ensino, podemos destacar duas idéias: a primeira, que as posições do assim chamado ensino tradicional (o conhecimento fora do aluno) e da Escola Nova (o conhecimento dentro do aluno) consistem em reducionismos; segunda, e em oposição, que a aquisição do conhecimento depende de uma série de fatores da realidade exterior (fatores históricos, sociais, antropológicos e culturais) e das capacidades pessoais (fatores de ordem psicológica).

\footnotetext{
${ }^{9}$ BRASIL. Secretaria de Educação Fundamental. Parâmetros Curriculares Nacionais: Terceiro e Quarto Ciclos do Ensino Fundamental: Introdução aos Parâmetros Curriculares Nacionais. Op. cit., p. 71.
} 
A aprendizagem, segundo o pensamento pedagógico atual, é o resultado da adequação dos fatores da realidade exterior às capacidades pessoais, possibilitando uma interação entre as partes. A essa maneira de pensar a aprendizagem dá-se o nome de interacionismo: "A realidade torna-se conhecida quando se interage com ela, modificando-a física e/ou mentalmente. A atividade de interação permite interpretar a realidade e construir significados, permite também construir novas possibilidades de ação e de conhecimento."10

Acredita-se que somente essa adequação, acima referida, permite a construção de representações que se orientam por uma lógica interna do aluno. Devido a essa lógica interna do aluno, uma construção inteligente da parte dele pode parecer incoerente para os outros, ou melhor, o que parece ser um erro, na verdade é uma construção. Essa nova perspectiva na compreensão da aprendizagem, supostamente oposta à tradição escolar, orienta-se, segundo a declaração oficial, pelos "enfoques cognitivos", que têm como marco de referência a teoria genética de Piaget e de outros teóricos do desenvolvimento que compõem o quadro da educação construtivista: uma nova "maneira de entender as relações entre aprendizagem e desenvolvimento e a importância conferida aos processos de relação interpessoal."11

No que se refere à relação interpessoal, a Pedagogia se defende da acusação de reproduzir o conceito de educação natural, característica do Escolanovismo, de uma postura espontaneísta, que proporia a liberdade total da criança em interação com o meio, para o "desabrochar" de "seu" conhecimento e o conseqüente apagamento do papel do professor. Com efeito, atualmente, fala-se da presença do professor e, mais do que isso, são-lhe propostas maneiras "adequadas" de interação com o aluno, no sentido de respeitar o momento de seu desenvolvimento, a sua individualidade, a sua natureza psicológica.

Pois bem, a segurança expressa pelo atual discurso pedagógico ao oferecer recomendações aos educadores, visando à adequação psicológica da intervenção, resulta das veneradas contribuições das investigações científicas sobre o "universo psicológico humano". Em outras palavras, não se fala mais de educação sem que se fale, fundamentalmente, sobre Psicologia. Portanto, ensinar passou a significar a adequação

\footnotetext{
${ }^{10}$ BRASIL. Secretaria de Educação Fundamental. Parâmetros Curriculares Nacionais: Terceiro e Quarto Ciclos do Ensino Fundamental: Introdução aos Parâmetros Curriculares Nacionais. Op. cit., p. 71 (grifo nosso).

${ }^{11}$ BRASIL. Secretaria de Educação Fundamental. Parâmetros Curriculares Nacionais: Terceiro e Quarto Ciclos do Ensino Fundamental: Introdução aos Parâmetros Curriculares Nacionais. Op. cit., nota de rodapé, p. 71 (grifo nosso).
} 
das atitudes do professor às singularidades da capacidade maturacional de seus alunos, como vemos neste trecho dos PCNs: "Isto é, a ação pedagógica deve se ajustar ao que os alunos conseguem realizar em cada momento de sua aprendizagem, para se constituir numa verdadeira ação educativa." 12

Para que o professor estabeleça a tão desejada relação "democrática", "cooperativa", de "respeito à natureza psicológica do aluno", deve conhecer as contribuições das teorias psicológicas desenvolvimentistas, identificar o momento de aprendizagem de cada aluno, além de suas expectativas, intenções, propósitos, interesses e habilidades particulares. Somente dessa maneira, pensa-se, poderá a Educação alcançar os objetivos que se propõe: "A partir do reconhecimento das diferenças existentes entre os alunos, fruto do processo de socialização e do desenvolvimento individual, a escola irá poten-cializar as capacidades dos alunos, ajustando sua maneira de selecionar e tratar os conteúdos, de modo a auxiliá-los a desenvolver, no máximo de sua possibilidade, as capacidades de ordem cognitiva, afetiva, física, ética, estética e as de relação interpessoal e de inserção social, ao longo do ensino fundamental."13

Vale ressaltar que, ao longo dos textos que compõem os PCNs, as expressões "potencializar capacidades" e "desenvolver capacidades" surgem constantemente. São, justamente, as teorias psicológicas do desenvolvimento que dizem sobre tais capacidades e como desenvolvê-las. Resulta daí uma dependência que exige da Pedagogia mudar na mesma velocidade das mudanças efetuadas no interior da Psicologia. Além disso, por acreditar em atitudes adequadas, ou ainda, na necessidade de adequação psicológica dos fatores externos às capacidades pessoais, o educador está condenado a "pensar" sobre suas atitudes em relação ao aluno, em suma, sobre a "relação".

Sendo assim, atualmente, toda a educação é pensada a partir do enfoque da "relação", gerando uma retrospectiva histórica depreciativa, a saber, a concepção de autoridade repressiva do professor no ensino tradicional e a total ausência de intervenção do professor Escolanovista. Logo, a "relação" ou "interação" professoraluno proposta pela Pedagogia atual vem evitar tais extremos. Em outras palavras, haveria, no passado da Educação, uma "falta de relação", "falta" esta causadora de problemas; agora, graças à ciência, acredita-se poder existir uma "relação ajustada". Em

\footnotetext{
${ }^{12}$ Idem, p. 72 (grifo nosso).

${ }^{13}$ Idem, p. 73 (grifo nosso).
} 
síntese, na dita Educação tradicional, o professor (autoritário) era o centro do processo; na Educação Nova, o centro era o aluno. Portanto, acredita-se que não havia "relação" em nenhuma das duas. Agora, a Pedagogia propõe uma "relação" psicologicamente (cognitiva e afetiva) ajustada entre os pólos.

Poderíamos dizer que, contrariando os modelos anteriores, a posição que o professor ocupa na "relação" professor-aluno, na Educação atual, é um tanto quanto "hesitante". Não é para menos. O objetivo de seu trabalho vai muito além daquele da transmissão cultural e da formação moral (ou de caráter) de outrora, pois, hoje, os conteúdos devem ser selecionados e abordados conforme as características psicológicas particulares de cada aluno e, mais ainda, ao professor de hoje cabe a tarefa de formar um aluno que "irá aprender a lidar com motivações, auto-estima, a adequar atitudes no convívio social, a valorizar o trabalho escolar, (...) compreender a si mesmo e aos outros, possibilitando o desenvolvimento da capacidade de relação interpessoal, que envolve compreender, conviver e produzir com os outros, com suas distinções, contrastes de temperamento, de intenções e de estados de ânimo." ${ }^{14}$ Ao professor atual cabe a formação do que poderíamos chamar de "indivíduos emocionalmente equilibrados", indivíduos "cognitivo-afetivamente ideais", isto é, alunos que se conformem às previsões e expectativas educacionais, que sejam disciplinados, que não desviem do caminho que lhes foi traçado no planejamento de ensino, que correspondam ao que a ciência psicológica prevê em suas teorias. Enfim, uma obsessão pelo ajuste psicopedagógico.

Voltando à posição do professor, para que se cumpra o atual ideal da Educação, para que se produza o ideal de aluno, a cena educativa deve ser conduzida nos moldes das prescrições psicológicas, sendo, dessa forma, uma prática adequada, eficaz, uma verdadeira "relação". Cabe deixar claro que não estamos questionando o suposto valor das teorias construtivistas sobre o desenvolvimento cognitivo ${ }^{15}$, mas a intenção pedagógica de se conformarem, professor e aluno, aos supostos modelos teóricos, ditando-lhes atitudes "cientificamente" justificadas que, na verdade, têm produzido ilusões em torno da idéia de adequação.

\footnotetext{
${ }^{14}$ BRASIL. Secretaria de Educação Fundamental. Parâmetros Curriculares Nacionais: Terceiro e Quarto Ciclos do Ensino Fundamental: Introdução aos Parâmetros Curriculares Nacionais. Op. cit., p. 74.

15 Não constitui objetivo deste trabalho analisar, particularmente, a validade das teorias construtivistas. Apenas extraímos do discurso da Pedagogia atual aquilo que ela chama de adequação ou ajustes entre o ato de ensinar e uma suposta natureza psicológica do aluno, como meio de se alcançar uma relação psicologicamente adequada.
} 
Vemos, atualmente, o discurso do professor impregnado de "saberes psicológicos". Cada segmento de sua prática deve estar científico-psicologicamente justificado; suas intervenções são mais adequadas, à medida que estão ajustadas às supostas capacidades psicológicas. Pensando a partir da psicologia infantil, o professor deixa de pensar em aluno e, mesmo que se fale conscientemente de aluno, pensa-se, na verdade, na criança em desenvolvimento. "Nesse processo, serão compartilhados saberes diferenciados, de professores e alunos, de adultos e crianças, adolescentes e jovens, ou seja, de indivíduos com histórias diversas, o que propicia a construção de conhecimentos diferenciados." ${ }^{16}$ Então, o professor deve saber, antes de tudo, o que se passa na cabeça da criança que está à sua frente.

Para que os objetivos educacionais correspondam a seu caráter "compartilhado", todos os saberes de dentro e de fora da escola devem ser tomados num mesmo nível. E, dessa forma, a cena educativa se amplia, à medida que procura absorver todos os que rodeiam as crianças e jovens em questão: “...questões apontadas a respeito da integração e cooperação, respeito à diversidade, desenvolvimento da autonomia, podem ser pensadas dentro da dinâmica de trabalho do diretor, do coordenador, dos professores, dos funcionários e dos pais, pois um projeto educativo só se realiza se os adultos envolvidos conseguem atuar de maneira integrada e cooperativa". ${ }^{17}$ Assim se compreende por que, atualmente, a família se sente apta para dizer ao professor como e o que deve ser feito com sua criança, já que é ela quem vai à escola, não mais o aluno.

Orientando os professores sobre "maneiras adequadas de interação" com crianças, adolescentes e jovens, a Pedagogia de hoje procura diferenciar-se do espontaneísmo da Escola Nova. E, considerando as particularidades, atribuindo valores iguais aos saberes oriundos das realidades que estão dentro e fora da escola, de adultos, crianças, jovens, pais, diretores, serventes, inspetores, ou qualquer outro cidadão que queira "interagir", dissolve-se a "tão perigosa", porque "autoritária", "relação" ("não relacionada") professor-aluno da assim chamada educação tradicional.

\footnotetext{
${ }^{16}$ BRASIL. Secretaria de Educação Fundamental. Parâmetros Curriculares Nacionais: Terceiro e Quarto Ciclos do Ensino Fundamental: Introdução aos Parâmetros Curriculares Nacionais. Op. cit., p. 86 (grifo nosso).

${ }^{17}$ BRASIL. Secretaria de Educação Fundamental. Parâmetros Curriculares Nacionais: Terceiro e Quarto Ciclos do Ensino Fundamental: Introdução aos Parâmetros Curriculares Nacionais. Op. cit., p. 89 (grifo nosso).
} 


\section{A Ilusória Relação Adequada da Pedagogia Atual}

Quando o que está em questão é a "relação" entre professor e aluno, a diferença é a razão desse encontro, pois se supõe que exista, por um lado, alguém que sabe; por outro, alguém que não sabe e precisa aprender. Uma diferença não só em termos de conhecimentos formais, mas de "experiência de vida". Portanto, quando a Pedagogia de hoje equipara os saberes dessa "relação", retira dela a diferença. E isso só é possível porque os professores estão (pre)ocupados com a adequação de suas atitudes à natureza psicológica das crianças e jovens.

A "relação adequada", para a Pedagogia dos nossos dias, é aquela que está em sintonia com as capacidades psicológicas (cognitivas e afetivas) supostamente naturais da criança. Isso nos possibilita questionar a defendida distinção entre o naturalismo existente na posição espontaneísta da Escola Nova e o culto à intervenção adequada, ou interacionismo, da Pedagogia atual. Como nos diz Leandro de Lajonquière: "Ora, se a intervenção deriva ou deve sua força à energia dada potencialmente às capacidades psicológicas, então, ela é uma pseudo-intervenção e, portanto, o caráter renovador - o dito interacionismo - do construtivismo pedagógico se desfaz com a figura de um aconchegante oásis no deserto, pois revela-se mais uma miragem naturalista." ${ }^{\text {,18 }}$

O interacionismo eqüivale a uma posição hesitante do professor, pois pensa-se que a autoridade é um elemento "antinatural”. Em prol de uma pretensa relação voltada para as individualidades, para as capacidades psicológicas naturais, o professor destituise da autoridade que está suposta na idéia de professor-aluno e passa a se "relacionar" com a criança. Em suma, a Pedagogia atual acredita que, para haver "relação", deva eliminar a autoridade, ou seja, abrir mão da diferença. Ainda nas palavras de Lajonquière: “O naturalismo psicopedagógico nunca formula nada que venha, por acaso, a fazer as vezes de uma negação - 'isso não’ e pronto. No máximo, esgrime argumentos 'racionais' sem muita convicção ou apela à sedução, pois não pode, sob nenhuma hipótese, fazer 'coisas não naturais'.”19

\footnotetext{
${ }^{18}$ Lajonquière, Leandro de. Infância e Ilusão (Psico)Pedagógica: Escritos de Psicanálise e Educação. Petrópolis, Vozes, 1999, p. 66.

${ }^{19}$ Idem, p. 73.
} 
Cabe ressaltar que não está sendo proposto aqui um retorno ao dito "autoritarismo retrógrado". O intuito é evidenciar a impossibilidade de se retirar a autoridade que consiste na diferença entre adulto e criança. Tirar a autoridade é acabar com a diferença. Se não há mais a diferença, alguém deixou o seu papel. A constante no avanço da Educação é que, quando um adulto se encontra diante de uma criança, começa a se perguntar o que se passa na cabeça das crianças, para adequar-se nessa "relação". Pois bem, com vistas a retirar o autoritarismo, o sadismo pedagógico, do contexto escolar, extraiu-se junto a autoridade derivada da diferença entre professor e aluno.

Dessa forma, uma característica que hoje se atribui ao ensino tradicional deve ser melhor analisada: a suposta autoridade do professor, inibidora da natureza do aluno, enquanto criança. Diz-se sobre a impessoalidade na "relação" entre o professor tradicional e seu aluno e, também, sobre a severidade com que se estabelecia a disciplina. Tais apontamentos não são totalmente improcedentes se pensarmos em determinadas práticas no campo educativo. Porém, o autoritarismo não é, necessariamente, exclusividade da pedagogia dos castigos corporais, tampouco deve ser confundido com a autoridade exercida pelo professor tradicional. Isto porque o autoritarismo pode estar mascarado de atitudes sedutoras, do tipo que procura convencer a criança de que o que se faz é com o seu consentimento, já que o discurso científico se supõe conhecedor do que uma criança quer. ${ }^{20}$ Além disso, quando algo se desvia desse saber sobre a criança, se esta não corresponde às previsões científicas, é encaminhada às especialidades clínicas que lhe mostrarão por onde retomar o caminho que, desde o início, lhe havia sido traçado. Então, o autoritarismo se reveste das "boas intenções" pedagógicas.

A Psicologia impregnou de tal forma o pensamento dos educadores que podemos percebê-la também na educação familiar. Pais preocupados em não frustrar o desenvolvimento natural de seus filhos procuram reconhecer-se nas condutas ideais ditadas pelas palestras proferidas por especialistas na escola, ou pelos manuais de educação de filhos, que hoje são verdadeiros best-sellers. Tanto os pais quanto os professores estão convencidos de que a criança possui capacidades que devem ser desenvolvidas naturalmente, por isso, suspendem a autoridade, "postura tão contrária à natureza das crianças".

\footnotetext{
20 Sobre as formas de perversão do dispositivo educativo, ver: Mannoni, Maud. "Uma Educação Pervertida”. In Educação Impossível. Rio de Janeiro, Francisco Alves, 1988, pp. 23-60.
} 
A autoridade não é algo que dependa do querer ou não querer consciente do adulto; é algo da estrutura mesma do encontro entre um adulto e uma criança. A Pedagogia de hoje procura defender-se dessa autoridade, como quem não quer assumir uma responsabilidade. Sobre a responsabilidade do professor, podemos ler em Hanna Arendt: "A qualificação do professor consiste em conhecer o mundo e ser capaz de instruir os outros acerca deste, porém sua autoridade se assenta na responsabilidade que ele assume por este mundo." ${ }^{21}$ A responsabilidade pela transmissão cultural, inerente à posição do professor e elo do encontro entre professor e aluno, atualmente se encontra submetida à proclamada "adequação" e o conhecimento acumulado ao longo da história, muitas vezes, reduzido ao lugar que lhe sobra, às vezes muito pouco ou quase nada. Assim compreende Cecília Cortez: "A idéia de regência de aula foi liminarmente classificada como autoritarismo. A grande cultura que servia de lastro e dava legitimidade à escola foi pensada como forma de dominação." ${ }^{22}$

No sentido de elucidar a afirmação sobre a recusa em assumir a responsabilidade atribuída à educação, orientar-nos-emos pelas proposições psicanalíticas, a fim de compreendermos que a Pedagogia moderna, apoiada nos saberes científicos embutidos em seu discurso psicopedagógico, se estrutura como uma neurose, isto é, se defende daquilo de que não pode se defender: a autoridade, a diferença legítima na posição ocupada pelo professor diante de um aluno, autoridade que todo adulto sustenta, ou deve sustentar, ao posicionar-se diante de uma criança, mesmo com todo o mal-estar que essa posição possa causar nesse adulto.

\section{A Autoridade e o Dispositivo da Ação Educativa}

O professor de outrora fazia seus alunos decorarem as lições, a tabuada, as conjugações de verbos, pedia que fizessem a cópia dos textos, em outras palavras, pedia aos alunos que fingissem ser adultos. Pois bem, isso nos dá o indício de que esse professor sabia não se tratar, na verdade, de adultos, mas sim de crianças. Por

\footnotetext{
${ }^{21}$ Arendt, Hanna. "Crise na Educação". In Entre o Passado e o Futuro. São Paulo, Ed. Perspectiva, 1972, p. 239.

${ }^{22}$ Souza, Maria Cecília C. C. de. À Sombra do Fracasso Escolar: A Psicologia e as Práticas Pedagógicas. In Estilos da Clínica: Revista Sobre a Infância com Problemas. São Paulo, Instituto de Psicologia da USP, Pré-Escola Terapêutica Lugar de Vida, ano 3, número 5, 1998, p. 79.
} 
conseguinte, podemos pensar que o dito professor tradicional reconhecia a diferença que constituía o seu encontro com aqueles candidatos a adultos (os alunos), porém denegava esta diferença e, por isso, colocava em circulação, na cena educativa, o seguinte pedido: "Para tornar-se adulto, e antes que se tornem, vocês devem fazer de conta que são." Por mais que se diga sobre uma inadequação do ensino tradicional ao lidar com os alunos, pois para os pedagogos de hoje não havia relação no ensino tradicional, o professor de outrora possuía uma sabedoria que podemos chamar intuitiva, ao lidar com a diferença entre ele e o aluno. Cecília Cortez fala-nos sobre tal sabedoria: "A escola tradicional 'sabia' que a criação, a originalidade e a inteligência não podiam ser objeto de uma ordem, não podem ser explicadas como metas, sob o risco da armadilha de colocar o aluno no lugar de objeto.",23

Atualmente, a ilusão que alimenta o discurso pedagógico resume-se em pretender recusar a diferença. Dizemos isto porque, diferente dos tempos passados em que o professor organizava sua prática a partir do reconhecimento da diferença, hoje ele a recusa, à medida que procura conformar seus alunos a um ideal psicológico ou nivelar sua bagagem cultural com a do aluno para, desta forma, "respeitá-lo". Percebemos que, quando ocorre uma preocupação exacerbada pela criança no aluno, pensa-se em termos de ajuste do conteúdo e da relação. E, mais ainda, parece que este ajuste à natureza da criança no aluno significa a recusa da diferença entre um adulto e uma criança que, às vezes, leva o adulto a infantilizar-se.

Ao tentar apagar a diferença (infantilizando-se, por exemplo), o professor desfaz o elo entre ele e o aluno, qual seja, o de responsabilizar-se pelo mundo e o de demarcar um lugar possível de se viver, à medida que transmite (e para além da transmissão) o conhecimento sobre a produção cultural acumulada pela humanidade, introduzindo o aluno numa tradição. Em lugar do conhecimento, hoje, a Pedagogia discursa teorias psicopedagógicas. Se antes a discussão pedagógica se articulava em torno dos conhecimentos e dos valores existenciais mínimos para um indivíduo habitar uma sociedade, hoje ela se faz a partir da suposta realização de um ideal de realidade psicopedagógica, através de atitudes psicopedagogicamente adequadas. Ou seja, pensase que as condições mínimas para habitar o mundo são dadas pelo ideal de desenvolvimento psicológico, alcançado através de um ajuste da "relação".

\footnotetext{
${ }^{23}$ Souza, Maria Cecília C. C. de. À Sombra do Fracasso Escolar: A Psicologia e as Práticas Pedagógicas. In Estilos da Clínica: Revista Sobre a Infância com Problemas. Op. cit., p. 73.
} 
Se podemos falar de uma crise enfrentada hoje pela Educação, compreendemos que esta não se deve à falta de adequação dos métodos às capacidades maturacionais, mas sim ao fato de o professor, "(pre)ocupado" com a singularidade psicológica de seus alunos, ter-se destituído da função educativa. ${ }^{24}$ Conseqüentemente, a ausência do adulto mantém a criança isolada em seu próprio mundo.

O fantasma do autoritarismo na Educação foi combatido à custa do desaparecimento da autoridade do professor. Este último não só deve saber sobre o que está latente no aluno como deve ajustar suas atitudes e o próprio conhecimento a ser transmitido à realidade de cada um na sala de aula. Procurando agir conforme uma certeza científica, o professor hesita antes de qualquer atitude, procura os manuais ou as palavras do especialista que, por sua vez, não hesitou em invadir a escola. Diz Lajonquière: "Essa espera - que não deve ser confundida com a atitude de cautela inerente à douta ignorância - implica a renúncia ao ato educativo." 25 Enquanto espera uma autorização para agir, renuncia ao ato. ${ }^{26}$

Aquilo que supostamente traria contribuições à prática do professor o faz ter medo e vergonha de cometer possíveis erros destruidores da natureza infantil. Paradoxalmente, ao pretender facilitar a aprendizagem, a Pedagogia acaba por torná-la de difícil realização.

O problema está na pretensão de saber prever e, dessa forma, controlar a educação com vistas a produzir um ideal de criança em termos cognitivos e emocionais. A Pedagogia, portanto, se propõe abraçar o impossível. E é justamente desconhecendo a impossibilidade, os limites que se impõem à educação, que a Pedagogia vai abrindo, cada vez mais, a distância entre aquilo que se faz na escola e aquilo que constitui o cerne da ação educativa. Catherine Millot deixa bem clara a origem da impossibilidade

\footnotetext{
${ }^{24}$ Segundo o pensamento presente da pedagogia, a causa dos tão mal falados fracassos escolares, bem como dos comportamentos indisciplinados, está na inadequação do manejo dos fatores externos, dentre eles uma interação desajustada do professor com a realidade psicológica do aluno. Supostamente, o domínio da atitude correta do professor diante de tais capacidades cognitivas garantiria o sucesso no alcance dos objetivos educacionais. Se a educação se encontra em crise, se hoje o estudante deixa a escola com uma bagagem de conhecimentos inferior à dos seus antecessores, se o fracasso escolar não sai das "manchetes" dos escritos pedagógicos, se o valor atribuído à escola caiu de tal maneira que estimula a invasão e a depredação, compreendemos que há algo de crítico no tratamento que a própria pedagogia vem dispensando à educação, mesmo que não o faça deliberadamente.

${ }^{25}$ Lajonquière, Leandro de. (Psico)Pedagogia, Psicanálise e Educação. Uma Aula Introdutória. In Estilos da Clínica: Revista Sobre a Infância com Problemas, São Paulo, Instituto de Psicologia da USP, PréEscola Terapêutica Lugar de Vida, ano 3, número 5, 1998, p. 129.

${ }^{26}$ Por mais que se fale, hoje, sobre uma prática educativa muito bem fundamentada, cientificamente justificada, o que vemos restar do conjunto das ilusões pedagógicas é, até certo ponto, uma omissão em relação ao ato de educar, ou ainda, os resultados escolares têm caminhado na contramão dos desejados efeitos educativos, levando a pedagogia, com frequiência, a ter de rever seus objetivos.
} 
da existência de uma ciência da Educação: "A descoberta do inconsciente tem o corolário de invalidar qualquer tentativa de construir uma ciência pedagógica que permita determinar os meios empregar para atingir determinado objetivo. $\mathrm{O}$ essencial do desenvolvimento psíquico do indivíduo escapa, por existir o inconsciente, a qualquer tentativa de domínio."27

Dizer da impossibilidade de uma ciência da Educação não significa dizer que nada pode ser feito para colocar em movimento o ato educativo. Tampouco significa defender a extinção dos métodos. Sempre existirá a busca do educador pelo "instrumento" ou a "via" que possibilite chegar a uma educação. No entanto, vemos que reside no discurso da Pedagogia atual a ilusão de uma linearidade entre o controle dos fatores externos (ambientais, podemos dizer) e a justa estimulação de um estado psicológico latente (pensamento do tipo causa e efeito, organismo-meio). É neste ponto, em que a Pedagogia tenta encontrar um "ajuste", uma "medida certa" para uma educação, que a Psicanálise lhe mostra a impossibilidade do controle do pedagogo sobre o resultado de seu empreendimento.

Tomemos mais uma vez as palavras de Leandro de Lajonquière: "Em toda educação está em questão a transmissão de um conjunto parcial de conhecimentos ou uma amostra daquilo que os outros souberam acumular com antecedência. Porém, aquele que aprende algo não só adquire um certo domínio sobre algum dos mundos possíveis - aquele das letras, da natureza, ou das virtudes humanas, dentre outros senão que também é marcado pelo apre(e)ndido no próprio coração da vida." ${ }^{28} \mathrm{Na}$ educação, ao mesmo tempo, circula algo da ordem do conhecimento e algo da ordem do saber. Este saber (saber sobre o desejo, saber suposto no professor), como veremos, compõe a realidade transferencial e, portanto, não é a mesma coisa que o pretendido relacional da Pedagogia de hoje. Isto quer dizer que, na transmissão do conhecimento, algo excede a atitude manifesta do professor e, por isso, os modelos malogram e, por isso, não há controle e previsão no interior da ação educativa. Esse algo que excede, podemos chamar de desígnios do inconsciente ou do desejo inconsciente, que impele o sujeito para a transferência.

A partir do referencial psicanalítico, compreendemos que a ação educativa se cumpre quando o aluno, movido pelo desejo de saber, investe na figura do professor, ao supor nele a posse do saber. Obviamente, para "alimentar" esse investimento, o

\footnotetext{
${ }^{27}$ Millot, Catherine. Freud Antipedagogo. Rio de Janeiro, Jorge Zahar Editor, 1995, p. 156.

${ }^{28}$ Lajonquière, Leandro de. Op. cit., pp. 167-168.
} 
professor deve sustentar a posição na qual é colocado. Como diz Cristina Kupfer: "Tudo o que esse aluno quer é que seu professor 'suporte' esse lugar em que ele o colocou. Basta isso."29

Apesar de parecer um tanto óbvio, simples e passível de controle ou manipulação (pois, bastaria ao professor fingir ser possuidor do "olho que tudo vê" para seduzir o aluno em direção à aprendizagem), esse lugar em que o professor é colocado não deixa de ser incômodo, uma vez que nele são depositados sentidos alheios ao professor enquanto pessoa. Em uma palavra, mesmo tendo de ocupar um lugar conferido pelo aluno, o professor nada sabe sobre esse lugar onde a subjetividade do aluno o coloca, por uma simples razão: é o desejo inconsciente que está determinando esse lugar.

A Psicanálise ensina-nos que não há possibilidade de um controle utilitário do desejo que move o desejo de saber. Em linhas gerais, podemos dizer que o aluno supõe no professor o saber sobre seu desejo e, dessa forma, espera dele o reconhecimento, em última instância, o amor. Nesse caso, o desejo se organiza num paradoxo: o desejo de saber é da ordem de um saber não sabido. Por sua vez, ao professor não é possível, nem mesmo lhe cabe, conhecer a maneira como se realiza o desejo de seu aluno. E, nesse sentido, a totalidade idealizada, essa completude que se convencionou chamar "relação professor-aluno" revela-se absolutamente utópica. A idéia de uma intervenção cientificamente ajustada à natureza psicológica da criança - o que parecia ser para a Pedagogia o "encontro educativo" - está marcada por um “desencontro" estrutural, uma impossibilidade inerente às relações.

Caberia então dizer que a relação, da maneira como é apreendida, consiste numa relação imaginária. Imaginária porque se encontra submetida à realidade do psiquismo dos sujeitos envolvidos na relação, seus desejos reprimidos, suas imagos, enfim, submetidos à singularidade de suas histórias e das redes de representações que compõem o inconsciente de cada um. Aquilo que se apreende de uma relação não é toda a realidade da "relação".

O inconsciente impõe um impossível à educação. Não há modelo de prática pedagógica imune ao imprevisto, nem que possa justificar e controlar cientificamente todos os seus efeitos. Marcelo Pereira assim descreve a relação pedagógica: "Nela reina também o residual de sombras, o irredutível, o indomável, cuja lógica se furta ao

\footnotetext{
${ }^{29}$ Kupfer, Maria Cristina M. Freud e a Educação: O Mestre do Impossível. São Paulo, Ed. Scipione, 1997, p. 93.
} 
universal e faz de professores e alunos seres estrangeiros entre si, fora da língua, invasores de territórios alheios, causadores de 'mal-estar', segundo a proposição psicanalítica." 30

Porém, veremos mais adiante que o mesmo desejo inconsciente, causador do mal-estar do (des)encontro entre professor e aluno, estabelece as condições para a educação.

Como já havíamos dito, o aluno, movido pelo desejo de saber, supõe o saber no professor. Obviamente, em decorrência disso, ao professor é conferido um poder que caracteriza a sua autoridade, ou seja, a autoridade do professor (que, como vimos, a Pedagogia recusa) não é deliberadamente imposta ao aluno, mas outorgada ao professor pelo próprio aluno.

Por outro lado, o professor é colocado diante de uma tentação, a saber, de abusar desse poder, dessa autoridade suposta. Ou seja, possuindo a confiança do aluno em relação aos seus saberes, o professor pode subjugar o desejo do aluno, impondo-lhe seu próprio desejo, pervertendo, então, a autoridade. Em suma, a autoridade é pervertida quando aquele em quem é suposto o saber, pelo inconsciente, se aproveita porque sabe que o outro the demanda amor e, de certa forma, lhe diz: "eu lhe ofereço o meu amor, o meu reconhecimento, à medida que você se anule como sujeito, que se submeta como objeto".

Pois bem, se o professor se coloca na posição de quem tudo sabe, não resta ao aluno desejo algum. Resta-lhe apenas submeter-se à figura do mestre. Cristina Kupfer adverte: "Nesse caso, a Educação fica subordinada à imagem de um ideal estabelecido logo de início pelo pedagogo e que, simultaneamente, proíbe qualquer contestação desse ideal. O que o pedagogo faz é pedir à criança que venha tão-somente dar fundamento a uma doutrina previamente concebida. Aqui, o aluno poderá aprender conteúdos, gravar informações, espelhar fielmente o conhecimento do professor, mas provavelmente não sairá dessa relação como sujeito pensante."31

Dessa maneira, a posição que o professor deve ocupar não é exatamente aquela em que o aluno o coloca, melhor dizendo, para que o aluno se constitua como sujeito pensante, o professor deve reconhecer-se castrado, isto é, um ser em falta. Ao mesmo tempo, não deve deixar sua posição de representante do conhecimento, ou melhor, de

\footnotetext{
${ }^{30}$ Pereira, Marcelo Ricardo. "O Relacional e seu Avesso na Ação do Bom Professor". In A Psicanálise Escuta a Educação. Eliane Marta Teixeira Lopes (org.), Belo Horizonte, Autêntica, 1998, p. 179.

${ }^{31}$ Kupfer, Maria Cristina. Op.cit., p. 93.
} 
representante do mundo adulto; deve sustentar a diferença que se aninha entre ele e o aluno. Caso contrário, o aluno não pode supor nele o saber, não se estabelece, portanto, o dispositivo da ação educativa.

A fim de tornar mais clara esta posição do professor, fazemos a distinção entre o saber suposto no professor pelo aluno (suposição inconsciente) e os saberes constituídos. O primeiro é da ordem de um saber não sabido, apenas suposto, pois se trata de um saber sobre o desejo. Ao mesmo tempo, é este saber suposto no professor que coloca o aluno na posição de dependência, desejando saber, e de participante da transmissão. Os saberes constituídos estão, sim, em andamento e, é claro, legalizam a função de professor e marcam a diferença entre ele e o aluno. No entanto, o conjunto de saberes produzidos pela civilização não pode residir, todo ele, em um professor. A dúvida que escapa no discurso do professor impede que o aluno se aliene nesse discurso, isto é, no professor não termina a suposição de tudo saber. O aluno permanece desejando saber e busca outras fontes.

Vimos que, na ação educativa se desenvolve um "jogo" em que as regras não são do domínio dos jogadores. Adiantamos que tal situação não é uma exclusividade do encontro entre professor e aluno, mas se repete em todo encontro entre dois seres humanos. Para compreendermos isso, devemos recorrer às proposições psicanalíticas sobre a transferência.

Sobre a figura do professor, e apesar de seu sentido enquanto pessoa, o aluno transfere algo que lhe pertence. A figura do professor passa a possuir um sentido atribuído pelo desejo do aluno. Que sentido é esse? Ou, o que se transfere? Recorremos a Freud para responder estas questões: "A natureza e a qualidade das relações da criança com as pessoas do seu próprio sexo e do sexo oposto, já foi firmada nos primeiros seis anos de sua vida. (...) Todos que vem a conhecer mais tarde tornam-se figuras substitutivas desses primeiros objetos de seus sentimentos.(...) Seus relacionamentos posteriores são assim obrigados a arcar com uma espécie de herança emocional, 
defrontam-se com simpatias e antipatias para cuja produção esses próprios relacionamentos pouco contribuíram."32

Apoiados nas proposições psicanalíticas, acreditamos que, a despeito do interesse relacional dos Parâmetros Educativos, a educação se dá naquilo que se processa no interior da ação educativa, bem como em todo encontro entre duas pessoas, naquilo a que Freud chamou transferência.

32 Freud, Sigmund. (1914b) Algumas Reflexões Sobre a Psicologia Escolar. Obras Psicológicas Completas de Sigmund Freud, Edição Standard Brasileira, vol. XIII, Rio de Janeiro, Imago, 1995, pp. 248-249. 


\title{
O CONCEITO DE TRANSFERÊNCIA
}

\begin{abstract}
“É preciso continuar, eu não posso continuar, é preciso continuar, é preciso pronunciar palavras enquanto as há, é preciso dizê-las até que elas me encontrem, até que me digam - estranho castigo, estranha falta, é preciso continuar, talvez já tenha acontecido, talvez já me tenham dito, talvez me tenham levado ao limiar de minha história, diante da porta que se abre sobre minha história, eu me surpreenderia se ela se abrisse."
\end{abstract}




\section{O CONCEITO DE TRANSFERÊNCIA}

"Designa em psicanálise o processo pelo qual os desejos inconscientes se atualizam sobre determinados objetos, no quadro de um certo tipo de relação estabelecida com eles e, eminentemente, no quadro da relação analítica.

Trata-se de uma repetição de protótipos infantis vivida com um sentimento de atualidade acentuada.

É à transferência no tratamento que os psicanalistas chamam a maior parte das vezes transferência, sem qualquer outro qualificativo.

A transferência é classicamente reconhecida como o terreno em que se dá a problemática de um tratamento psicanalítico, pois são a sua instalação, as suas modalidades, a sua interpretação e a sua resolução que caracterizam este.” (LAPLANCHE, J.; PONTALIS, J.-B. Vocabulário da Psicanálise. São Paulo, Martins Fontes, 1992, p. 514.)

Acreditamos que toda análise da relação educativa alicerçada na teoria psicanalítica exige uma pesquisa cuidadosa sobre o desenvolvimento do conceito de transferência no interior da própria teoria. O motivo desta afirmação é o fato de encontrarmos tentativas de se empregarem as contribuições psicanalíticas no contexto educativo $^{33}$, cujas propostas nos levaram a acreditar num descuido próprio do momento em que se isola um conceito do conjunto teórico em que está inserido.

Tal pesquisa nos parece ser o único caminho possível aos profissionais interessados nas relações humanas, entre eles os educadores, que se propõem circular pelo terreno das proposições psicanalíticas, sem caírem em grandes equívocos, como, entre outros, o de desenvolverem modelos de relacionamentos (expressos na ilusão de um modelo de relação que garanta a aprendizagem), ou de trocarem o papel de professores pelo de analistas em sala de aula.

\footnotetext{
${ }^{33}$ Encontramos no texto "Sobre o Conceito de Transferência no Campo Pedagógico", de Janine Filloux. In Revue Française de Pédagogie, número 87, p. 59-75, abril-maio-junho de 1989, uma exposição sobre o movimento da pedagogia psicanalítica entre 1926 e 1937. Nele, constatamos as dificuldades e os limites da aplicação da Psicanálise à pedagogia, ilustrados pelos primeiros trabalhos que se propuseram fundar uma nova prática pedagógica, a exemplo do pastor Pfister. Trataremos mais sobre essa questão no terceiro capítulo deste trabalho.
} 
Poderíamos antecipar que o que deveria interessar a esses profissionais "afins" é a transferência como fenômeno constitutivo das ligações objetais, das ligações com o outro, ou melhor, os "lugares" simbólicos que estão sendo ocupados nessa "relação". Somente assim teriam uma visão mais clara do que se processa nas relações de modo geral, segundo as concepções psicanalíticas. Por outro lado, enquanto ferramenta específica do trabalho analítico, como eixo em torno do qual o trabalho analítico visa a substituir repetição por construção, interessa exclusivamente ao analista. Em outras palavras, a compreensão do fenômeno da transferência pode permitir esclarecer a natureza do ato educativo, porém tal estudo não se presta diretamente à prática pedagógica.

Como forma de justificarmos a antecipação precedente, assim como para abranger a discussão sobre o desenvolvimento do conceito de transferência no interior da Psicanálise, recorremos aos textos freudianos que, como observa Daniel Lagache ${ }^{34}$, trazem poucos títulos que empregam diretamente o termo transferência e, apesar disto, a literatura do conceito é inesgotável, pois a transferência está por toda parte em Psicanálise.

Também são imprescindíveis, para este trabalho, as contribuições de Lacan. Ele trouxe a proposta de um "retorno a Freud", no sentido de pulverizar as "distorções" sofridas pela Psicanálise, através de uma releitura que alguns autores definem estruturalista.

Podemos apontar como pontos fundamentais nos textos lacanianos as discussões sobre a constituição do sujeito, sobre o desejo enquanto motor do psiquismo e o estabelecimento da transferência.

\footnotetext{
${ }^{34}$ Lagache, Daniel. A Transferência, São Paulo, Martins Fontes, 1990, p. 3.
} 


\section{O CONTEXTO FREUDIANO}

$\mathrm{Na}$ história da teoria da transferência, existem particularidades que tornam difícil sua reconstituição: "A literatura da transferência é inesgotável, já que a transferência está por toda parte em Psicanálise; e, no entanto, estaríamos tentados a dizer que não está em parte alguma: se a literatura técnica é pouco abundante, a literatura da transferência é pobre; há inclusive poucos títulos que empregam explicitamente o termo transferência." ${ }^{35}$ Diante disto, cada autor que se dispõe a esta tarefa apresenta a necessidade de estabelecer uma organização da exposição, na tentativa de abrangê-la, sem, porém, escapar de algumas lacunas.

Proporemos uma organização (dentre outras possíveis) das "intervenções” da transferência na obra freudiana:

1. A primeira delas estaria nas relações de Freud com seus amigos, colegas estimados e mestres (entre outros, Charcot, Breuer e Fliess). Portanto, a transferência vivida por quem a conceituou.

2. A segunda intervenção manifesta, na dificuldade que foi sendo imposta ao tratamento, uma resistência a ser superada e, até então, sem possuir valor teórico. A transferência no trabalho clínico com seus pacientes ${ }^{36}$.

3. E, finalmente, seu reconhecimento como elemento inerente às relações, além de condição para o trabalho analítico.

\section{A Transferência de Freud}

Uma pesquisa minuciosa que pretenda colocar em evidência os conteúdos transferenciais das relações de Freud tem como fonte abundante as muitas cartas que este endereça aos amigos (e à noiva, na época em que sua vida profissional se iniciava), e cujo conteúdo, por vezes, trata de suas relações com terceiros, ora constituídas de

\footnotetext{
${ }^{35}$ Lagache, Daniel. Op. cit. p. 3.

${ }^{36}$ Como no caso Dora, onde a transferência fica evidente. Ver: Freud, Sigmund. (1905a) Fragmento da Análise de um Caso de Histeria. Obras Psicológicas Completas de Sigmund Freud, vol. VII, Rio de Janeiro, Imago, 1988.
} 
muita afeição ora de um grande rancor, assim como as relações com Breuer e Jung, entre outros.

Sabemos que tais personagens foram tão importantes no desenvolvimento da teoria quanto o foram na vida afetiva de Freud, alguns mais eminentes em um ou em outro período. Por isso, é possível dizer que a Psicanálise, o movimento do pensamento freudiano, é fruto da dinâmica psíquica de Freud, dos afetos presentes nas suas relações com seus mestres, discípulos, pacientes, amigos, familiares, opositores, dissidentes etc. Enfim, como Freud mesmo escreveu, a história da Psicanálise confunde-se com sua história: "Dois temas ocupam essas páginas: a história de minha vida e a história da psicanálise. Elas se acham intimamente entrelaçadas. Esse Estudo Autobiográfico mostra como a psicanálise veio a ser todo o conteúdo de minha vida..., 37

Longe de pretendermos esgotar uma análise de suas relações, faremos uma breve incursão no que poderíamos chamar de uma amostra das "relações significativas" na vida de Freud. E, tendo em vista o grande número de personagens que fizeram parte do cenário da Psicanálise, elegeremos, como representantes deste conjunto, Charcot, Breuer e Fliess que, de uma forma ou de outra, participaram da gestação (a partir de 1885), do nascimento (aproximadamente 1893) até 1901, pouco depois da publicação de A Interpretação de Sonhos (1900), muitas vezes considerada a obra de grande impulso teórico ${ }^{38}$, portanto, dos primeiros (grandes) "passos” da Psicanálise.

Antes de nos aventurarmos nesta primeira parte da pesquisa sobre o conceito de transferência (uma breve abordagem das relações de Freud), existem alguns elementos importantes em sua história de vida que devem ser lembrados ${ }^{39}$ : Freud era o filho mais velho do segundo casamento de seu pai. Sua família depositava nele uma grande expectativa em relação à sua vida profissional, gerando no filho uma responsabilidade em corresponder a ela e, conseqüentemente, o desejo de conhecer e compreender as coisas. Assim, desde o início de sua escolarização, foi um aluno exemplar, sempre debruçado sobre os livros.

Para abordarmos as questões relativas à vida acadêmica de Freud, utilizaremos as informações fornecidas pela própria pessoa em questão: Freud escreve um texto, em

\footnotetext{
${ }^{37}$ Freud, Sigmund. (1935a) Pós-Escrito de (1924b) "Um Estudo Autobiográfico". Obras Psicológicas Completas de Sigmund Freud, vol. XX, Rio de Janeiro, Imago, 1988, pp. 75-78.

${ }^{38} \mathrm{O}$ valor atribuído ao texto A Interpretação de Sonhos de 1900 tem como motivo principal a mudança do modelo de aparelho psíquico. Até então, estava atrelado às referências da neurologia (assim como encontramos em Projeto de uma Psicologia de 1895), portanto, um modelo orgânico, naturalista, e, a partir de então, passa a buscar outras referências, com destaque à filosofia.

${ }^{39}$ Tais elementos receberam um tratamento minucioso nas biografias feitas por Ernest Jones (1953), o biógrafo "autorizado" por Freud, e por Peter Gay, que lançou seu trabalho trinta anos após o de Jones.
} 
1924, intitulado Um Estudo Autobiográfico ${ }^{40}$ : "Quando eu era uma criança de quatro anos (1860), fui para Viena e ali recebi toda minha educação. No ‘Gymnasium' [escola secundária] fui o primeiro de minha turma durante sete anos (...)"41 Freud habita no mesmo endereço até 1938, um ano antes de sua morte (1939), quando se muda para Londres, por força da perseguição nazista.

Conta-nos Freud que nunca pôde identificar em si mesmo qualquer predileção pela carreira de médico. Por outro lado, havia uma preocupação com questões humanas que o atraía para outros campos de interesse: o direito (as atividades sociais), por influência de um amigo mais velho, que se tornou um conhecido político; e a filosofia ${ }^{42}$. Foi a leitura de um ensaio sobre a Natureza, atribuído a Goethe (cujo verdadeiro autor, descoberto posteriormente, é G. C. Tobler, escritor suíço, em 1780) que o conduziu à Medicina em 1873, formando-se, tardiamente, em 1881.

$\mathrm{Na}$ universidade, experimentou a decepção com o preconceito contra sua origem judaica, um dos fatores que o fez considerar-se na oposição, alheio à "maioria compacta". Além disso, havia as dificuldades que atribuiu às peculiaridades e limitações de seu dom, negando-lhe o sucesso em muitos campos da ciência. Tais limitações justificam o caráter difuso de seus estudos nos primeiros anos de universidade. E sua condição financeira precária levou seu professor Ernest Brücke ${ }^{43}$ a indicar-lhe a área da neurologia. Antes disso, dedicava-se às pesquisas em fisiologia, que agora eram dirigidas e utilizadas no estudo do sistema nervoso. Assim, estabeleceu-se uma inclinação para concentrar seus trabalhos num "problema" que orientou toda sua vida profissional: do funcionamento do sistema nervoso para o funcionamento do psiquismo humano.

Cabe lembrar que, no percurso da história de Freud, existem inúmeras minúcias que não são menos importantes do que as abordadas neste trabalho. Esta rápida exposição da biografia freudiana serve-nos apenas para situarmos o período em que a Psicanálise começa a ser gestada. É a partir daí que "entram em cena” os anteriormente

\footnotetext{
40 Freud, Sigmund. (1924b) Um Estudo Autobiográfico. Obras Psicológicas Completas de Sigmund Freud, vol. XX, Rio de Janeiro, Imago, 1988, pp. 9-78.

${ }^{41}$ Idem, pp. 15-16.

${ }^{42}$ Carta de 8 de dezembro de 1895. In Masson, J.F. (org.) Correspondência Completa de Sigmund Freud para Wilhelm Fliess - 1887-1904. Rio de Janeiro, Imago, 1986, p. 155.

${ }^{43}$ Ernest Wilhelm von Brücke (1819-1892), professor de fisiologia do laboratório em que Freud ingressou em 1876, e permaneceu até 1882, e onde estabeleceu contato com "homens que pude respeitar e tomar como modelos" (Um Estudo Autobiográfico. Op. cit., p. 17). Mestres significativos que precederam uma série de outros mestres.
} 
chamados representantes das primeiras relações "mais significativas": Charcot, Breuer e Fliess.

Em 1885, Freud recebe da Universidade de Viena uma bolsa de estudos e parte para Paris com a promessa de encontrar materiais novos para sua pesquisa em neuropatologia, pois considerava já haver recebido as principais contribuições que as universidades alemã e austríaca poderiam lhe oferecer. Além disso, existia um médico renomado, Jean-Martin Charcot (1825-1893), que desenvolvia "métodos" novos no trabalho clínico (o uso da hipnose e a pesquisa sobre a histeria), rejeitados pelos médicos alemães. Foi sobretudo porque “à distância brilhava o grande nome de Charcot" ${ }^{\text {"4 }}$ que Freud se dirigiu ao Hospice de la Salpêtrière.

Se é possível dizer que Ernest Brücke deu um "empurrão" na direção das pesquisas de Freud, diríamos que Charcot representa o "tiro de largada" para o nascimento da Psicanálise. Foi nesse período de permanência em Paris que o interesse de Freud transferiu-se da neuropatologia para a psicopatologia. Isto se deve, claramente, à forte influência que a figura de Charcot exerceu sobre ele. Para ilustrarmos isso, não encontramos registro melhor do que as palavras de Freud em uma carta endereçada à sua noiva, logo depois de ter chegado a Paris, em 24 de novembro de 1885: "Acho que estou mudando muito. Vou dizer-lhe detalhadamente o que me está afetando. Charcot, que é um dos maiores médicos e um homem cujo senso comum tem um toque de gênio, está simplesmente desarraigando minhas metas e opiniões. Por vezes, saio de suas aulas como se estivesse saindo da Notre Dame, com uma nova idéia de perfeição. Mas ele me exaure; quando me afasto, não sinto mais nenhuma vontade de trabalhar em minhas próprias bobagens; há três dias inteiros não faço qualquer trabalho, e não tenho nenhum sentimento de culpa. Meu cérebro está saciado, como se eu tivesse passado uma noite no teatro. Se a semente frutificará algum dia, não sei; o que sei é que ninguém jamais me afetou dessa maneira..." 45

Por várias vezes Freud se referiu a Charcot como "o grande homem” e pôde encontrar neste inúmeras qualidades: força física, vigor mental, a natureza de um artista,

\footnotetext{
${ }^{44}$ Freud, Sigmund. (1924b) Um Estudo Autobiográfico. Obras Psicológicas Completas de Sigmund Freud, vol. XX, Rio de Janeiro, Imago, 1988, p. 19.

${ }^{45}$ Trecho encontrado na "Nota do Editor" que antecede o obituário que Freud escreveu poucos dias após a morte de Charcot. Freud, Sigmund. (1893) Charcot. Obras Psicológicas Completas de Sigmund Freud, vol. III, Rio de Janeiro, Imago, 1994, pp. 19-20 (grifo nosso).
} 
a perfeição formal no falar, paciência, amor pelo trabalho, sinceridade... ${ }^{46}$ Algo, talvez, tenha decididamente contribuído para uma identificação com este mestre: sua obstinação pela compreensão dos casos o levava a observar incansavelmente o mesmo fenômeno, a admitir a dificuldade de interpretá-lo, a repetir seus esforços para uma visão correta do significado de um sintoma. Para isso, permitia-se extrapolar os pressupostos da medicina teórica, o que causava um estranhamento nos estudantes. Encontravam-se, portanto, Charcot e Freud, em posições semelhantes: na oposição, por serem, talvez, dois "espíritos" regidos pelo desejo de saber sobre as coisas. Uma expressão de Charcot deixou marcas indeléveis no pensamento freudiano; quando interpelado pela observação de um aluno que apontava a incoerência entre o que estava sendo dito e uma determinada teoria, disse: “La théorie, c'est bon, mais ça n'empêche pas d'exister" ["Teoria é bom, mas não impede que as coisas existam"].

A interpretação da influência exercida por Charcot na vida de Freud não é originalmente nossa, mas do próprio Freud: "Das diversas lições a mim prodigalizadas no passado (1885-6) pelo grande Charcot, na Salpêtrière, duas deixaram profunda impressão em mim: que jamais devemos nos fatigar de considerar os mesmos fenômenos repetidas vezes (ou de nos submeter a seus efeitos), e que não devemos nos importar quando depararmos com a contradição de todos os lados, de vez que tenhamos trabalhado com sinceridade." 47

Quando ainda desenvolvia suas pesquisas no laboratório de Brücke, Freud tem seu primeiro contato com um dos médicos de família mais respeitados pela sociedade médica da época, e que apresentava, assim como ele, um grande interesse científico: Joseph Breuer (1842-1925). Este lhe conta sobre o tratamento peculiar que vinha dispensando ao caso de uma paciente com sintomas histéricos, a saber, a hipnose seguida da indução do relato, pela paciente, sobre aquilo que lhe oprimia a mente. Este método de tratamento ficou conhecido, posteriormente, por método catártico, e se diferenciava do método que Freud utilizou durante um curto período (hipnose seguida de sugestão para o desaparecimento do sintoma), pelo fato de não influenciar o paciente,

\footnotetext{
46 Freud, Sigmund. (1886) Relatório Sobre Meus Estudos em Paris e Berlim. Obras Psicológicas Completas de Sigmund Freud, vol. I, Rio de Janeiro, Imago, 1988, pp. 35-49.

${ }^{47}$ Freud, Sigmund. (1924a) Carta a Le Disque Vert. Obras Psicológicas Completas de Sigmund Freud, vol. XIX, Rio de Janeiro, Imago, 1976, p. 323.
} 
mas "recuperar" o que estava nele mesmo. Os sintomas do paciente desapareciam quando ele encontrava por si mesmo sua origem. Tal caso, cuja paciente recebeu o pseudônimo de Anna O., passou a ser foco do interesse de Freud, especialmente quando de seu retorno do estágio em Paris, no ano de 1886 (o caso já havia sido encerrado em junho de 1882), ficando admirado com o cuidado e a paciência com que Breuer aplicava seu método.

Breuer desempenhou um importante papel no início da vida profissional de Freud. Não apenas pelo estímulo proporcionado por sua influência, mas também financeiramente representou um grande provedor quando Freud passava por dificuldades. Breuer possuía uma grande clientela, enquanto Freud iniciava sua carreira. O resultado de tamanha aproximação foi a produção de uma obra em conjunto Estudos Sobre a Histeria, publicada aproximadamente em 1895 (a data exata não foi indicada), além do fato de suas famílias passarem a manter estreitas relações.

Toda admiração que marcou o início da amizade entre Breuer e Freud foi dando lugar a divergências na abordagem da teoria, até atingir a relação profissional e pessoal. A primeira divergência foi relativa ao mecanismo psíquico presente na histeria: "Ele dava preferência a uma teoria que, se poderia dizer, ainda era até certo ponto fisiológica; tentava explicar a divisão mental nos pacientes histéricos pela ausência de comunicação entre vários estados mentais (...), e construiu então a teoria dos “estados hipnóides" (...). Eu via a questão de forma menos científica; parecia discernir por toda parte tendências e motivos análogos aos da vida cotidiana, e encarava a própria divisão psíquica como efeito de um processo de repulsão que naquela época denominei de 'defesa', e depois de 'repressão'."48

É mais comum acreditar que havia uma resistência de Breuer em admitir a etiologia sexual das neuroses, apesar de haver no texto dos Estudos Sobre a Histeria indícios de uma posição crédula diante de tal pressuposto: "Foi-nos portanto impossível fazer uso de algumas das nossas observações mais instrutivas e convincentes (...) Assim, ocorre que só conseguimos apresentar provas muito incompletas em favor de nosso ponto de vista de que a sexualidade parece desempenhar um papel fundamental na patogênese da histeria (...). Foram precisamente as observações de natureza

\footnotetext{
${ }^{48}$ Freud, Sigmund. (1914c) A História do Movimento Psicanalítico. Obras Psicológicas Completas de Sigmund Freud, vol. XIV, Rio de Janeiro, Imago, 1988, p. 21.
} 
marcadamente sexual que nos vimos obrigados a não publicar." 49 Porém, a reação da sociedade médica da época, tanto em Viena quanto na Alemanha, diante da publicação dos Estudos... não foi favorável. Pelo contrário, a obra foi alvo de pesadas críticas, o que, provavelmente, desencorajou Breuer, que não se dispôs a arriscar seu prestígio. Freud também afirmava a recusa do colega: "Breuer fez o que pôde, por mais algum tempo, para lançar na balança o grande peso de sua influência pessoal a meu favor, mas nada conseguiu, sendo fácil constatar que também ele se esquivou de reconhecer a etiologia sexual das neuroses."

No entanto, Freud nos diz que o motivo real da separação entre eles não foi de ordem teórica, mas uma questão muito mais profunda que apenas pôde ser compreendida posteriormente. E tal questão nos interessa sobremaneira. Quando questionado por Freud sobre a etiologia dos sintomas de Anna O., Breuer nega qualquer relação com o tema da sexualidade, apesar do simbolismo presente no caso (as cobras, o enrijecimento, a paralisia do braço, as dores semelhantes à de um parto quando Breuer partia em viagem com sua esposa). "No tratamento desse caso, Breuer usou, para com a paciente, de um rapport sugestivo muito intenso, que nos poderá servir como um perfeito protótipo do que chamamos hoje de "transferência'."51 Ao deparar com a motivação sexual da transferência, Breuer, naquele momento incapaz de reconhecer sua natureza universal, interrompeu o caso e encaminhou sua paciente a um colega. ${ }^{52}$ Podemos concordar com Freud quando afirma que na transferência, existente entre médico (Breuer) e paciente (Anna O.), encontra-se o cerne do repúdio do colega pela etiologia sexual das neuroses.

Em 1909, nas conferências proferidas na Universidade de Clark $^{53}$, Freud chega a atribuir o mérito de fundador da Psicanálise a Breuer, e sempre considerou o método

\footnotetext{
${ }^{49}$ Breuer, Joseph; Freud, Sigmund. "Prefácio à Primeira Edição" de Estudos Sobre a Histeria (1893-95). Obras Psicológicas Completas de Sigmund Freud, vol. II, Rio de Janeiro, Imago, 1995, p. 33. (Um dos poucos trechos da obra que escreveram realmente juntos).

${ }^{50}$ Breuer, Joseph; Freud, Sigmund. "Prefácio à Primeira Edição" de Estudos Sobre a Histeria (1893-95). Obras Psicológicas Completas de Sigmund Freud, vol. II, Rio de Janeiro, Imago, 1995, p. 32.

${ }^{51}$ Freud, Sigmund. (1914c) A História do Movimento Psicanalítico. Obras Psicológicas Completas de Sigmund Freud, vol. XIV, Rio de Janeiro, Imago, 1988, p. 22.

52 Bertha Pappenheim, verdadeiro nome de Anna O., 21 anos, inteligente, de personalidade e físico atraentes, amiga antiga de Martha (esposa de Freud) foi internada numa instituição em estado muito conturbado, período em que Breuer confessa a Freud que gostaria que sua ex-paciente morresse para que se livrasse dos seus sofrimentos. Aos trinta anos tornou-se a primeira assistente social na Alemanha, uma das pioneiras em todo o mundo. Jones, Ernest. Vida e Obra de Sigmund Freud. vol. I, Rio de Janeiro, Zahar Editores, 1970, pp. 237-238.

${ }^{53}$ Freud, Sigmund. (1910a) Cinco Lições de Psicanálise (pronunciadas por ocasião das comemorações do vigésimo aniversário da Fundação da Clark University, Worcester, Massachusetts, em setembro de 1909). Obras Psicológicas Completas de Sigmund Freud, vol XI, Rio de Janeiro, Imago, 1970, p. 13.
} 
catártico como precursor imediato da Psicanálise. Também é muito comum encontrar em seus escritos expressões de gratidão, admiração, e de desgosto pelo desentendimento subseqüente, entre elas a afirmação de que, no trabalho realizado em conjunto com Breuer, somente ele mesmo foi favorecido diante da experiência e inteligência do colega e amigo. "Adquirimos o hábito de partilhar todos os nossos interesses científicos. Nessa relação só eu naturalmente tive a ganhar. O desenvolvimento da psicanálise, depois, veio custar-me sua amizade. Não me foi fácil pagar tal preço, mas não pude fugir a isso." 54

A relação com Wilhelm Fliess (1858-1928), médico especialista em nariz e garganta que residia em Berlim, iniciou ainda enquanto trabalhava com Breuer, em 1887, e permaneceu até 1902. Inclusive, foi a Fliess que Freud contou sobre seus principais sentimentos por Breuer, sobretudo sua perplexidade, sua irritação diante das atitudes ambíguas do colega. ${ }^{55}$ Dessa relação com Fliess renderam muitas cartas que manifestam, "nas entrelinhas", a questão da transferência. Afirmamos isto devido à própria afetividade que marcava essa relação, facilmente percebida nas expressões carinhosas que Freud dirigia a Fliess (não podemos dizer sobre as expressões de Fliess, pois suas cartas não foram encontradas). Além disso, existia uma "estranha” idealização que Freud dirigia ao amigo e que discutiremos a seguir. Esses elementos levaram muitos leitores a considerar esse período como o do início da assim chamada análise de Freud, e que ele mesmo tratou, durante um curto período, como sua auto-análise. ${ }^{56}$

Outro fato salientado pela leitura de muitos psicanalistas é que a comunicação entre os amigos se deu no momento da produção do texto A Interpretação de Sonhos

\footnotetext{
${ }^{54}$ Freud, Sigmund. (1924a) Um Estudo Autobiográfico. Obras Psicológicas Completas de Sigmund Freud, vol. XX, Rio de Janeiro, Imago, 1988, p. 26.

${ }^{55}$ Carta de 6 de fevereiro de 1896: "Simplesmente não consigo mais me entender com Breuer; o que tive de suportar nos últimos meses em termos de maus tratos e fraco discernimento, que é, apesar disso, engenhoso, finalmente me insensibilizou internamente para essa perda. Mas, por favor, não diga nenhuma palavra a esse respeito que possa bater novamente por aqui." In: Masson, J. F. (org.) Correspondência Completa de Sigmund Freud e Wilhelm Fliess - 1887-1904. Rio de Janeiro, Imago, 1986, p. 171.

${ }^{56}$ Carta de 22 de junho de 1897: "A propósito, venho atravessando uma espécie de experiência neurótica, estados curiosos que são incompreensíveis para a consciência, pensamentos crepusculares e dúvidas veladas, com um pálido raio de luz aqui e ali." Idem, p. 255. (Veremos mais adiante nesse trabalho algumas considerações sobre a auto-análise e as limitações nela implicadas. Compreenderemos, então, que a análise só é possível com a existência de um outro [na transferência], que neste caso é Fliess, portanto, não é uma análise feita sozinha como sugere o termo auto-análise. Aliás, já na época dessa carta, Freud afirmava que as forças que atuam na resistência das pessoas em saber sobre sua neurose são as mesmas da formação dessas neuroses).
} 
(1900), um grande marco na obra freudiana. ${ }^{57}$ Portanto, um período de intensa produção teórica (podemos dizer que, não por acaso, um período também de afetos intensos: grande hostilidade por Breuer e ampla admiração por Fliess).

É possível observar, com as leituras das cartas, as tentativas de Fliess de justificar as teorias de Freud por origens fisiológicas, o que o levou a desenvolver investigações que hoje consideraríamos absurdas. Uma delas sobre duas supostas substâncias que agiriam nas pessoas em geral, em intervalos diferentes: uma masculina (a cada vinte e três dias, de caráter aprazível), outra feminina (a cada vinte e oito dias, de caráter desprazível). A predominância da substância masculina constituiria o indivíduo perverso; a predominância da substância feminina constituiria o indivíduo neurótico; e o equilíbrio entre as duas substâncias resultaria num indivíduo normal. ${ }^{58}$ Além dessa, formulou uma teoria sobre a bissexualidade dos seres humanos em geral, e uma outra que afirmava ter o nariz a mesma estrutura dos órgãos genitais.

Freud aceitava as formulações de Fliess com tamanha (e não menos absurda) credibilidade que se esforçava para contribuir com esses "delírios", procurando traçar paralelos entre seus trabalhos, e admitindo nele mesmo os "períodos especiais" das substâncias descobertas por Fliess ${ }^{59}$. Ao mesmo tempo que supervalorizava a inteligência do amigo: “Com respeito a suas revelações na fisiologia sexual, tudo o que posso fazer é manter a postos a mais ávida atenção e admiração crítica. Meus conhecimentos são limitados demais para que eu dê alguma contribuição."60 "Ainda não pude fazer nenhuma contribuição para a questão dos períodos e datas. É provável que você também não esperasse grande coisa." 61

A confiança depositada em Fliess vai mais longe na produção teórica de Freud, levando-o até a questionar suas referências psicológicas: "Com respeito à teoria do recalcamento, esbarrei em dúvidas que poderiam ser dissipadas por algumas palavras suas, em particular sobre a menstruação masculina e feminina num mesmo indivíduo. Angústia, fatores químicos e assim por diante - quem sabe, com sua ajuda, descobrirei a fundamentação sólida que me permita parar de dar explicações psicológicas e começar a

\footnotetext{
${ }^{57}$ Existem autores que acreditam num primeiro surgimento do termo transferência no texto sobre os sonhos, apesar de podermos verificá-lo nos textos anteriores. Entre estes autores encontramos: Strychman, Nicole. "Historicidade do Conceito de Transferência". In Dicionário de Psicanálise: Freud \& Lacan I. Salvador, Ágalma, 1994, pp. 266-267.

${ }^{58}$ Carta de 6 de dezembro de 1896. In Masson, J.F. (org.) Correspondência Completa de Sigmund Freud e Wilhelm Fliess - 1887-1904. Op. cit., p. 213.

${ }^{59}$ Por exemplo, na carta de 9 de junho de 1896. Idem, pp. 193-194.

${ }^{60}$ Carta de 8 de dezembro de 1895. Idem, p. 156.

${ }^{61}$ Carta de 26 de Abril de 1896. Idem, p. 184.
} 
descobrir uma base fisiológica!"62 Mais ainda, Freud achava-se devedor nessa amizade: "Quantas coisa lhe devo: consolo, compreensão, estímulo em minha solidão, o sentido de minha vida, que adquiri por seu intermédio, e, por fim, até mesmo a saúde, que ninguém mais poderia ter-me restituído!"63

As explicações possíveis para essa relação plena de sentimentos generosos podem ser tiradas do fato de, como se sabe, Fliess ser um pouco mais novo que Freud e mais avançado na profissão, o que permitiu a formação de uma imagem idealizada. Diante disso, experimentou os efeitos da transferência sem poder, ainda, compreendê-la: “Ainda não sei o que está acontecendo comigo. Algo proveniente das mais recôndidas profundezas de minha própria neurose insurgiu contra qualquer progresso na compreensão das neuroses e, de algum modo, você foi envolvido nisso. Isso porque minha paralisia redacional me parece destinada a inibir nossa comunicação. Não tenho nenhuma garantia disso, apenas sentimentos de natureza altamente obscura. Não terá nada desse tipo acontecido com você?"64

Nosso interesse em retomar algumas passagens sobre a relação de Freud com esses personagens é mostrar a existência de alguns processos que se repetem, ou melhor, que, de uma forma ou de outra, estão presentes em cada uma das relações, mesmo guardadas as suas singularidades. Estamos falando de um "movimento" que pode ser assim sintetizado: uma grande admiração inicial (idealização), grandes expectativas, superação e abandono. Isto nos levará a um primeiro ingresso na compreensão do conceito de transferência.

Lembremos da "missão" delegada a Freud por sua família: tornar-se um grande homem. Podemos dizer que essas figuras notáveis (Charcot, Breuer e Fliess) serviam como uma tela onde Freud projetava seu futuro. "Os homens com quem rompeu (Fliess, Jung $\left[\right.$ e Breuer] ${ }^{65}$ ) foram aqueles de quem, de início, esperava muito. Um elemento

\footnotetext{
${ }^{62}$ Carta de 30 de junho de 1896. Idem, p. 194.

${ }^{63}$ Carta de $1^{\circ}$ de janeiro de 1896, In Masson, J.F. (org.) Correspondência Completa de Sigmund Freud e Wilhelm Fliess - 1887-1904. Op. cit., p. 159.

${ }_{65}^{64}$ Carta de 7 de julho de 1897, Idem, p. 256.

${ }^{65}$ Acréscimo nosso.
} 
'irracional', que mais tarde a elucidação da noção de transferência tornaria mais claro, estava em ação aí, e com rara violência.",66

Podemos compreender que esses amigos estavam, na verdade, ocupando a posição de mestres, pois, em se tratando de profissionais de destaque na área em que atuavam, Freud atribuía-lhes um saber superior que o deixava na posição de dependência.

Mas, o futuro almejado por Freud significava a autoria de um novo conhecimento (vale aqui lembrar seu interesse pelas questões sociais). Na verdade, Freud esperava ser reconhecido por uma grande contribuição científica, se assim podemos dizer. Para isso, era necessário tornar-se "seu próprio mestre", ou seja, superar os demais. E, como superar não significa abandonar radicalmente o que foi transmitido, são as pró- prias palavras de Freud que vão nos situar em relação ao papel desempenhado por alguns de seus mestres: "Enquanto escrevia minha 'História do Movimento Psicanalítico', em 1914, vinham-me à mente algumas observações que me tinham sido feitas por Breuer, Charcot e $\mathrm{Chrobak}^{67}$, as quais poderiam ter me conduzido mais cedo a essa descoberta [a excitação de natureza sexual em ação nos fenômenos da neurose]. Mas na ocasião em que as ouvi não compreendi o que essas autoridades queriam dizer; na realidade haviam-me dito mais do que elas próprias sabiam ou estavam preparadas para defender., 68

Isso que Freud nos diz sobre o desconhecimento dos mestres (e, até certo ponto, o seu próprio), sobre aquilo que estavam transmitindo, desencadeia uma série de discussões sobre "um saber que não se sabe" subjacente aos mecanismos psíquicos inconscientes. Este saber, ou desejo de saber (ou, ainda, o desejo de não saber), que será melhor abordado mais adiante nesse trabalho, seria o dispositivo que atraía Freud para junto de seus mestres e, posteriormente, o repelia. Isso também nos permitirá compreender as "relações" presentes na ação educativa, que é nosso objetivo central.

\footnotetext{
${ }^{66}$ Mannoni, Octave. Freud: Uma Biografia Ilustrada. Rio de Janeiro, Jorge Zahar Editor, 1994, p. 58.

${ }^{67}$ Breuer explicava para Freud, certa vez, a origem de um caso de "doença nervosa": "Estas coisas são sempre 'secrets d'alcôve' ('leito conjugal')". Charcot comenta, de forma reservada a Brouardel (nomeado Professor de Medicina Legal em Paris em 1879), sobre uma mulher com doença grave, cujo marido era impotente: "Mas nesses casos é sempre a coisa genital, sempre, sempre!". E, Chrobak, ginecologista renomado, prescreve ironicamente "penis normalis, doses repetidas..." a uma paciente que encaminhou a Freud, esta sofria de acessos de ansiedade só acalmados quando sabia onde se encontrava seu médico (seu marido era impotente). Freud, Sigmund. (1914c) A História do Movimento Psicanalítico. Op. cit., pp. 2325.

${ }^{68}$ Freud, Sigmund. (1924b) Um Estudo Autobiográfico. Obras Psicológicas Completas de Sigmund Freud, vol. XX, Rio de Janeiro, Imago, 1988, p. 30.
} 
O papel de discípulo que Freud soube desempenhar diante das figuras influentes com as quais deparou, relacionava-se (como veremos com mais profundidade no decorrer desse trabalho) com a figura paterna que tinha internalizado. A diferença imaginária, que desencadeava a idealização desses personagens, refletia a diferença entre ele próprio como criatura e seu pai, primeiro mestre, como criador. Foi, portanto, a superação da diferença que marcava seu lugar (de quem "não sabe e deseja saber") em oposição ao lugar de alguém que sabe (supostamente seu pai tinha o saber sobre ele), que operou o movimento de tornar-se seu próprio mestre.

Enfim, Freud cumpre sua missão passando de aprendiz para mestre (apesar de acreditarmos nunca ter abandonado um ou outro mestre em definitivo, pois os “diálogos" permaneceram nele); por outro lado, suas inquietações levaram-no a conservar uma posição de eterno aluno. “(...) provavelmente qualquer escola the teria sido de grande utilidade, pois Freud já tinha dentro de si aquilo que escola alguma pode ensinar: o desejo de saber." 69

\section{A Pré-História da Transferência}

"Se na época [1882] não cheguei por conta própria à conclusão que Moebius estabeleceu depois - de que os êxitos no tratamento elétrico em doentes nervosos são efeito de sugestão - foi, sem dúvida alguma, apenas por causa da total ausência desses prometidos êxitos." ${ }^{, 70}$ Diríamos que basicamente dois problemas acompanharam Freud durante um longo tempo de sua produção: a etiologia e o tratamento dos transtornos mentais. No que se refere ao tratamento, de início, seu trabalho clínico foi auxiliado pelos métodos preconizados pela Psiquiatria da época (eletroterapia, por exemplo), depois, influenciado pela escola de Naney (em 1889), aplicou a hipnose seguida de sugestão; ao conhecer o método catártico de Breuer, deixou a sugestão (mantendo ainda a hipnose). Foi a resistência de alguns pacientes a se submeterem à hipnose que levou Freud a conhecer uma nova via de acesso ao inconsciente, a saber, a associação livre.

\footnotetext{
${ }^{69}$ Kupfer, Maria Cristina. Freud e a Educação: O Mestre do Impossível. São Paulo, Ed. Scipione, 1997, p. 22.

${ }^{70}$ Freud, Sigmund. (1914c) A História do Movimento Psicanalítico. Obras Psicológicas Completas de Sigmund Freud, vol. XIV, Rio de Janeiro, Imago, 1988, p. 20.
} 
A evolução da técnica psicanalítica é a própria história da descoberta da transferência e do desenvolvimento da sua teoria. Tudo isto, como sabemos, foi movido pelo desejo de saber que imperava em Freud. Nas palavras de Lagache: “(...) a genialidade de Freud consistiu em converter as dificuldades em instrumentos. Cada dificuldade, cada fracasso, foi o ponto de partida de uma pesquisa psicológica e de uma inovação técnica. Se todos os pacientes tivessem sido hipnotizáveis, não teria havido psicanálise: e, nesse sentido, pode-se sustentar que a psicanálise nasceu da resistência e dos efeitos negativos da transferência.,"71

Desde o método da catarse (quando submetidos à hipnose, os pacientes deveriam lembrar-se do evento causador da neurose) havia uma força psíquica que constantemente se manifestava e que era preciso ser superada: a resistência. Para vencêla, a relação médico-paciente era colocada em questão, embora tratada ainda de maneira superficial.

O primeiro texto dedicado diretamente à transferência, A Dinâmica $d a$ Transferência, foi publicado em 1912. Até aí, o tema já tinha alcançado importante proporção e profundidade. Para acompanharmos seu desenvolvimento, estabeleceremos uma organização cronológica de algumas publicações.

Em 1895, Freud e Breuer publicam Estudos Sobre a Histeria ${ }^{72}$. No capítulo intitulado A Psicoterapia da Histeria, de autoria exclusiva de Freud, é abordada a necessidade de o paciente confiar no terapeuta para que haja a sugestão, isto é, para que ocorra a submissão à técnica que utilizava na época (tanto no caso da hipnose, quanto da pressão na testa): "Na verdade, parece que tal influência por parte do médico é uma condição sine qua non para a solução do problema." ${ }^{, 73}$ E ele nos diz de outra condição imposta ao tratamento: que ele próprio, como terapeuta, possuísse um interesse pessoal pelo paciente. Evidentemente, sem fazer qualquer menção ao termo contra-transferência que usará muito depois.

Encontramos nesse mesmo texto uma expressão bastante interessante ao referirse à postura do médico diante das resistências do paciente, algo como representar $o$

\footnotetext{
${ }^{71}$ Lagache, Daniel. A Transferência. Op. cit., pp. 6-7.

${ }^{72}$ Breuer não quis participar do último texto, onde é mais efetivamente tratada a etiologia sexual das neuroses. Nós o destacamos como precursor da discussão sobre a transferência.

${ }^{73}$ Freud, Sigmund. (1893-95) Estudos Sobre a Histeria. Op. cit., p. 281.
} 
papel de infalíveis, que proporcionaria maior sucesso à insistência do médico na revelação das representações inconscientes: "Trabalha-se com o melhor da própria capacidade, como elucidador (ali onde a ignorância deu origem ao medo), como professor, como representante de uma visão mais livre ou superior do mundo, como o padre confessor que ministra a absolvição, por assim dizer, pela permanência de sua compreensão e de seu respeito depois de feita a confissão."74 A influência pessoal do médico seria responsável pela eliminação da resistência, e, nos casos de constrangimento diante de conteúdos eróticos, o empenho e a cordialidade do mesmo seriam um substituto do amor ${ }^{75}$, compensando o sacrifício pessoal.

Acreditamos ser possível afirmar que em 1893 Freud já havia avançado na conceitualização da transferência, como pode ser verificado nas últimas páginas do texto citado. A transferência é caracterizada por obstáculos à análise, apresentando-se de três formas: por uma desavença pessoal, pelo pavor em tornar-se dependente do médico e pelo medo de se ver transferindo para o médico as representações aflitivas.

Esta última forma da transferência merece maior reflexão, pois, além de ser a primeira vez que a palavra "transferência" ("Ubertragung”) é empregada em toda obra freudiana, a elaboração que se segue aproxima-se consideravelmente das formulações posteriores mais específicas.

"Essa é uma ocorrência freqüente e, a rigor, usual em algumas análises. A transferência para o médico se dá por meio de uma falsa ligação. (...) Desde que descobri isso, tenho podido, todas as vezes que sou pessoalmente envolvido de modo semelhante, presumir que a transferência e uma falsa ligação tornaram a ocorrer. Curiosamente, a paciente volta a ser enganada todas as vezes que isso se repete." distinção que podemos notar com o que hoje é aceito consta do caráter acentuadamente circunstancial atribuída à transferência, isto é, sua presença não é constante.

A expressão falsa ligação denota o produto de uma divisão no conteúdo da consciência, e pode ser assim compreendida: existiu no passado um desejo recalcado que, no presente, na relação com o médico, foi desperto. Diante disso, o paciente resiste em dar acesso a tal desejo clandestino. ${ }^{77} \mathrm{O}$ caminho da superação desse obstáculo à

\footnotetext{
${ }^{74}$ Idem, p. 295.

75 Em 1914, Freud escreve Observações Sobre o Amor Transferencial. Lacan retoma esse tema ao analisar e reformular o conceito de transferência. Trataremos disso mais adiante.

${ }^{76}$ Freud, Sigmund. (1893-95) Estudos Sobre a Histeria. Op. cit., p. 313-314.

77 Encontramos uma explicação mais esclarecedora sobre o papel de tal divisão do conteúdo da consciência na transferência, no texto publicado muito posteriormente, A Dinâmica da Transferência (1912).
} 
técnica terapêutica (a força da resistência resultante da falsa ligação) seria torná-lo consciente ao paciente.

“A princípio, fiquei muito aborrecido com esse aumento de meu trabalho psicológico, até que percebi que o processo inteiro obedecia a uma lei; e então notei que esse tipo de transferência não trazia nenhum aumento significativo para o que eu tinha de fazer. (...) Aos poucos, também os pacientes aprenderam a compreender que nessas transferências para a figura do médico tratava-se de uma compulsão e de uma ilusão que se dissipava com a conclusão da análise." ${ }^{78}$ Também é possível concluir que a transferência era prerrogativa do tratamento psicanalítico, melhor dizendo, em Estudos sobre a Histeria a transferência era considerada um fenômeno que ocorria exclusivamente no tratamento clínico. Assim permanece durante um longo período da obra, até ser retomado, dezessete anos depois, no texto dedicado ao tema da transferência. ${ }^{79}$

Mesmo dando destaque aos obstáculos impostos pela transferência, é notável a aproximação da investigação de Freud - desde a origem da teoria psicanalítica (como o que encontramos nesse texto escrito em 1895) - com a gênese da transferência e de seus efeitos na terapêutica. Consideramos um grande passo na compreensão da transferência sua descoberta como manifestação do despertar do mesmo afeto que, originalmente, forçou o paciente a rejeitar o desejo inaceitável.

Acompanhando a cronologia, encontraremos o termo transferência em Traumdeutung (1900), onde Freud nos fala de substituições de lembranças infantis por "transferência", de pensamentos de transferência, transferências de representações, transferências de desejos inconscientes para os restos diurnos, enfim, utiliza o termo de maneira supostamente diferente do conhecido, isto é, trata-se de um modo de deslocamento. Precisamos dedicar maior atenção ao sentido dessas expressões voltando-nos ao núcleo teórico desenvolvido nesse texto.

A produção do conteúdo onírico é o resultado da força exercida pelo desejo inconsciente e da resistência das instâncias psíquicas superiores (a censura); então, nos

\footnotetext{
${ }^{78}$ Freud, Sigmund. (1893-1895) Estudos Sobre a Histeria. Op. cit., p. 315.

79 "Não é fato que a transferência surja com maior intensidade e ausência de coibição durante a psicanálise que fora dela." Freud, Sigmund (1912) A Dinâmica da Transferência. Obras Psicológicas Completas de Sigmund Freud, Rio de Janeiro, Imago, 1970, p. 113.
} 
sonhos, identificamos o movimento do desejo inconsciente no sentido de se fazer escutar. Nesse sentido, apodera-se de lembranças do que aconteceu no dia anterior (restos diurnos), dando-lhes um outro sentido, isto é, esvazia-as do significado que trouxeram no momento de suas manifestações e oferece-lhes um novo significado.

No que se refere à dinâmica dos sonhos, ou à sobredeterminação do conteúdo do sonho, devemos nos lembrar do que Freud chamou de conteúdo manifesto e conteúdo latente. O cerne deste último é o inconsciente, e a interpretação do conteúdo manifesto, tendo sua forma final definida na elaboração secundária, revela o sonho como realização de desejo, sendo este um conteúdo recalcado e infantil de natureza sexual. Enfim, o desejo inconsciente propulsiona a formação do conteúdo onírico.

A censura, possuindo um papel primordial no impedimento da expressão do desejo inconsciente, conseqüentemente, determinará o desenvolvimento dos mecanismos que possibilitarão a expressão indireta do mesmo: a condensação e o deslocamento. "O deslocamento do sonho e a condensação do sonho são os dois fatores dominantes a cuja atividade podemos, em essência, atribuir a forma assumida pelos sonhos." 80 A condensação designa um processo psíquico primário que aponta uma tendência do trabalho do sonho a fundir numa unidade todas as fontes que determinaram o sonho, isto é, a combinação de representações com "auto grau de interesse psíquico", ou melhor, hiperintensas. O deslocamento consiste na escolha de uma representação como depositária da condensação e, como sabemos, esta representação guarda poucas semelhanças com as originais. Assim, o desejo recalcado manifesta-se à medida que se encontra deslocado para uma representação anódina, portanto, disfarçado numa representação aceitável à consciência.

O sentido do termo transferência no texto sobre os sonhos, tal como encontramos nas expressões acima, diz respeito à transferência de intensidades psíquicas decorrente dos processos de condensação e deslocamento que produzem os sonhos, o que podemos verificar na expressão "ocorrem uma transferência $e$ deslocamento de intensidades psíquicas no processo de formação de sonhos" $"$. Sabemos que, no decorrer da obra freudiana, a transferência adquire um sentido que vai explicar algo da ordem da relação analítica e, sucessivamente, as relações que se encerram na vida dos indivíduos de modo geral, poderíamos dizer, na vida do neurótico.

\footnotetext{
${ }^{80}$ Sigmund Freud, “O Trabalho do Deslocamento". In (1900) A Interpretação de Sonhos, parte I. Obras Psicológicas Completas de Sigmund Freud, vol. IV, Rio de Janeiro, Imago, 1987, p. 333.

${ }^{81}$ Idem, p. 333.
} 
Miller aponta para o caráter estrutural da transferência: "Nesse sentido, a transferência (...) é o processo geral das formações do inconsciente - o sonho, o lapso, o chiste; (...) o desejo se mascara e se aferra a significantes esvaziados, enquanto tais, de significação." $" 82$

A fim de marcar a evolução do tratamento do conceito de transferência, selecionamos uma passagem de A Interpretação de Sonhos onde o conceito se insere na compreensão do funcionamento geral do psiquismo humano, deixando seu caráter anteriormente mais específico: “.... representação inconsciente, como tal, é inteiramente incapaz de penetrar no pré-consciente, e (...) só pode exercer ali algum efeito estabelecendo um vínculo com uma representação que já pertença ao pré-consciente, transferindo para ela sua intensidade e fazendo-se 'encobrir' por ela. Aí temos o fato da 'transferência', que fornece uma explicação para inúmeros fenômenos notáveis da vida anímica dos neuróticos., 83

Nos três últimos meses de 1899, Freud atende Dora e redige o caso logo depois; porém, apenas é publicado em 1905, com um pós-escrito não datado. Foi precisamente o abandono precoce do tratamento por Dora que fez surgir em Freud a necessidade de escrever sobre o caso e, conseqüentemente, identificar os efeitos da transferência e sua inabilidade, naquele momento, em lidar com ela.

Desde o início do tratamento, ficou claro para Freud que Dora o colocava na posição de pai, comparando-o com ele e buscando verificar a sinceridade de Freud, uma vez que se sentia enganada pelo pai. No primeiro sonho Dora faz um alerta em relação ao abandono do tratamento, e dessa vez era a partir de afetos que dirigia ao Sr. K. transferidos para Freud. "Mas fiquei surdo a essa primeira advertência, pensando haver tempo, de sobra, já que não se apresentavam outros estágios da transferência e ainda não se esgotara o material para a análise. Assim, fui surpreendido pela transferência e, por causa desse ' $x$ ' que me fazia lembrar-lhe o Sr. K., ela vingou-se de mim como queria vingar-se dele, e me abandonou como se acreditara enganada e abandonada por ele.

\footnotetext{
${ }^{82}$ Miller, Jacques-Alain. Percurso de Lacan: Uma Introdução. Rio de Janeiro, Jorge Zahar Editor, 1997, p. 59.

${ }^{83}$ Freud, Sigmund. "Realização de Desejos". In (1901) A Interpretação de Sonhos, parte II. Op. cit., pp. 591-592.
} 
Assim, atuou uma parte essencial de suas lembranças e fantasias em vez de reproduzilas no tratamento." 84

As "transferências" são "reedições, reproduções das moções e fantasias que, durante o avanço da análise, soem despertar-se e tornar-se conscientes, mas com a característica (própria do gênero) de substituir uma pessoa anterior pela pessoa do médico." ${ }^{~} 5$ A transferência surge ora como reedição inalterada de fantasias vividas no vínculo atual com a pessoa do médico, ora apresenta-se como edição revista e submetida a uma sublimação.

Freud vê-se obrigado a discutir sobre a transferência, pois revela tê-la compreendido como incontornável, tendo como função produzir todos os empecilhos que tornam o material inacessível ao tratamento. O paciente atua ao invés de rememorar na análise. Assim, a transferência é reconhecida como um novo "produto" do processo neurótico e que, assim como os outros sintomas, deve ser "repetidamente aniquilada". "A transferência, destinada a constituir o maior obstáculo à psicanálise, converte-se em sua maior aliada quando se consegue detectá-la a cada surgimento e traduzi-la para o paciente. ${ }^{86}$ É considerada, então, uma exigência indispensável em toda análise, pois a análise e liquidação constante da transferência são as condições do sucesso da investigação e do tratamento. Freud percebe que a cura se dá pela figura do médico (mais precisamente, pela transferência), e não pelo método.

Destacamos uma afirmação do texto sobre o caso Dora que ampliará o estudo sobre o "fenômeno" da transferência: "O tratamento não cria a transferência, mas

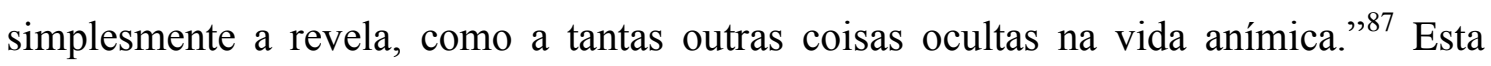
afirmação possibilita duas outras: que a Psicanálise não inventou a transferência, mas estuda e trabalha seus efeitos; e que a transferência não pode mais ser pensada como um privilégio da análise.

\section{A Teoria da Transferência}

\footnotetext{
${ }^{84}$ Freud, Sigmund. (1905a) Fragmento da Análise de um Caso de Histeria. Op. cit., p. 113.

${ }^{85}$ Freud, Sigmund. (1905a) Fragmento da Análise de um Caso de Histeria. Op. cit., p. 111.

${ }^{86}$ Idem, p. 112.

${ }^{87}$ Idem, p. 112.
} 
Posteriormente à publicação do caso Dora em 1905, Freud produz uma série de outros trabalhos que, apesar de não tratarem diretamente do tema da transferência, a tem, como já foi afirmado no início, como "pano de fundo", uma vez que nunca deixou a experiência clínica; pelo contrário, seu trabalho clínico representou sempre uma fonte generosa de reflexões. Isso nos leva a acreditar que durante o intervalo que se seguiu, entre 1905 e 1910, um amadurecimento do conceito de transferência foi sendo gestado.

A partir de 1911, Freud elabora um conjunto de textos que têm por objetivo discutir a técnica psicanalítica. Desse conjunto denominado Artigos Sobre a Técnica selecionaremos três textos que nos interessam de perto: A Dinâmica da Transferência (1912), Recordar, Repetir e Elaborar (1914) e Observações Sobre o Amor Transferencial (1915 [1914]).

Em A Dinâmica da Transferência encontramos um esforço de explicação sistemática sobre o lugar da transferência na análise: "Gostaria de, nas páginas seguintes, acrescentar algumas considerações destinadas a explicar como a transferência é necessariamente ocasionada durante o tratamento psicanalítico, e como vem ela a desempenhar este seu conhecido papel." Este texto pode ser considerado o mais representativo trabalho dedicado ao conceito da transferência. Nele se encontra desenvolvida uma reflexão que parte de uma explicação sobre a disposição constitucional à transferência (da transferência em geral); depois, de como ela se especifica no contexto analítico e, finalmente, o papel do analista no que se refere ao manejo da transferência.

Tratando, então, da constituição da disposição à transferência, é possível retomarmos a expressão falsas ligações, ainda pouco elaborada, no texto Estudos Sobre a Histeria (1895). Podemos compreendê-la a partir da distinção que Freud faz entre uma parte dos impulsos que completou o desenvolvimento psíquico (voltada para a realidade) e outra que, tendo sido impedida de expandir-se, fora retirada do curso do desenvolvimento, permanecendo inconsciente. As atitudes dos pacientes seriam, então, formadas por ambas as partes e comporiam os clichês estereotípicos, segundo a série de representações nas duas instâncias. Assim, as catexias eram formadas por antecipação, melhor dizendo, as falsas ligações seriam as possíveis catexias com a figura do médico, segundo as “séries” psíquicas (séries de representações) já formadas pelo paciente. 
Em linhas gerais, a capacidade de amar que um indivíduo possui é caracterizada pela reedição freqüente de um clichê estereotípico que determina as "condições" dessa capacidade.

Em termos freudianos, a transferência surge como resistência à análise, pois as imagos infantis que haviam sido reprimidas são postas novamente na realidade, dessa vez na realidade do contexto analítico. Portanto, é justamente uma resistência em retirar a parte da libido que se encontra em seu esconderijo (o inconsciente), especialmente diante das condições exigidas pela associação-livre. ${ }^{88}$

Podemos compreender melhor agora a razão pela qual a transferência era tratada, em seus primórdios, como prejuízo à análise: ela realmente se caracteriza como resistência, em outras palavras, procura conservar o estado de coisas, isto é, mantém o material recalcado afastado da consciência. E continua sendo assim compreendida nas proposições lacanianas, porém, com traços de particularidade da teoria que serão analisados mais adiante.

Uma outra consideração a ser feita sobre a resistência que caracteriza a transferência, ainda no contexto do pensamento freudiano, é o que ele chamou de resistências transferenciais particulares, divididas em: transferências "positivas", de sentimentos afetuosos; e "negativas", de sentimentos hostis. Numa primeira leitura, poderíamos acreditar que apenas as transferências "negativas" imporiam resistência ao tratamento; porém, um pouco mais adiante, nesse mesmo tex to que estamos analisando, constatamos que também as chamadas "positivas" são apropriadas à resistência. Estas, apesar de aceitas pela consciência, possuem prolongamentos inconscientes que remontam às fontes eróticas, e que, assim como todo restante do material inconsciente, recusa sua revelação: “Os impulsos inconscientes não desejam ser recordados da maneira pela qual o tratamento quer que o sejam, mas esforçam-se por reproduzir-se de acordo com a temporalidade do inconsciente e sua capacidade de alucinação."

Existe ainda a questão da ambivalência, comum na transferência de modo geral, em grau elevado no caso dos neuróticos que fazem resistência ao tratamento analítico. A ambivalência da transferência é descrita por Lagache: "Assim, cada pensamento, cada ato mental do paciente, é um compromisso entre as forças que impelem ao tratamento e as forças mobilizadas para se opor a ele." 90

\footnotetext{
${ }^{88}$ Freud, Sigmund. (1912) A Dinâmica da Transferência. Op. cit., p. 114.

${ }^{89}$ Idem, p. 119.

${ }^{90}$ Lagache, Daniel. A Transferência. Op. cit., p. 19.
} 
Esse fenômeno (a transferência) surgirá espontaneamente no tratamento, uma vez que o paciente ligará a figura do analista aos afetos anteriormente dirigidos a outras pessoas. Um aspecto importante a ser considerado é o agente provocador da transferência do analisando para o analista. Ressaltamos que não se trata de uma transferência entre duas pessoas (uma relação), mas de uma transferência do paciente para o analista. Poderíamos dizer que tal fenômeno é desencadeado pela situação mesma em que o paciente se encontra: submetido à única regra do tratamento, mais precisamente à associação-livre. Pois, a resistência da transferência só tem sentido diante da posição interpretativa do analista, na sua expectativa pela revelação do conteúdo recalcado.

Essa discussão sobre o papel do analista no desencadeamento da transferência, já apresentada por Freud, torna-se mais clara a partir das contribuições de Lacan, das quais logo nos ocuparemos.

Na exposição do caso Dora (1905), vimos que Freud relata a atuação que surge no lugar da rememoração, atuação expressa, nesse caso, no abandono do tratamento pela paciente. É no texto Recordar, Repetir e Elaborar (1914) que encontramos uma reflexão mais específica sobre o papel da repetição na análise e sua relação com a transferência.

Em primeiro lugar é necessário compreender que o esquecimento significa, via de regra, uma interceptação do conteúdo aflitivo (e que já fora recalcado). Estamos falando da resistência. A incapacidade de recordar, a resistência, vem acionar, então, uma disposição à repetição. “(...) o paciente não recorda coisa alguma do que esqueceu e reprimiu, mas expressa-o pela atuação ou atua-o (acts it out). Ele o reproduz não como lembrança, mas como ação; repete-o, sem, naturalmente, saber que o está repetindo."91

Estaríamos propensos a pensar que a repetição seria um impedimento para o trabalho analítico. No entanto, Freud afirma ser a repetição uma forma de recordar do paciente $^{92}$ e que o manejo da transferência é o instrumento que o fará substituir a

\footnotetext{
${ }^{91}$ Freud, Sigmund. (1914a) Recordar, Repetir e Elaborar. Obras Psicológicas Completas de Sigmund Freud, vol. XII, Rio de Janeiro, Imago, 1988, p. 165.

${ }^{92}$ Idem, p. 166.
} 
compulsão à repetição pela recordação e elaboração. Freud faz questão de frisar que esta característica do trabalho analítico é o que o distingue de qualquer tipo de tratamento que tem como instrumento a sugestão.

“O que nos interessa, acima de tudo, é, naturalmente, a relação desta compulsão à repetição com a transferência e com a resistência. Logo percebemos que a transferência é, ela própria, apenas um fragmento da repetição e que a repetição é uma transferência do passado esquecido, não apenas para o médico, mas também para todos os outros aspectos da situação atual. (...) Também o papel desempenhado pela resistência é facilmente identificável. Quanto maior a resistência, mais extensivamente a atuação (acting out) (repetição) substituirá o recordar, pois o recordar ideal do que foi esquecido, que ocorre na hipnose, corresponde a um estado no qual a resistência foi posta completamente de lado." 93 Concluímos que o desenvolvimento das resistências determina o das repetições, e dentre as formas de repetição encontra-se a transferência.

$* * *$

As considerações relativas à transferência "positiva" encontram-se mais ostensivamente trabalhadas no texto Observações Sobre o Amor Transferencial (1915). Freud o inicia lembrando-nos do clássico caso Anna O. e seus efeitos sobre as dificuldades experimentadas por Breuer, e que caracterizaram os primórdios da Psicanálise. $^{94}$

Para que entendamos o fenômeno induzido pela situação analítica é necessário avaliarmos o que se processa no paciente (a transferência) e também no analista (a contratransferência). Partiremos do primeiro.

"Ele [o analista] evocou este amor, ao instituir o tratamento analítico a fim de curar a neurose. Para ele, trata-se de conseqüência inevitável de uma situação médica, tal como a exposição do corpo de um paciente ou a comunicação de um segredo vital."95 Compreendemos daí que o amor reflete a confiança necessária para a submissão ao tratamento, assim como sua "promessa" de cura. Ou ainda, a suposição pelo analisando sobre a capacidade do analista de compreender e dissolver seus conflitos.

\footnotetext{
${ }^{93}$ Freud, Sigmund. (1914a) Recordar, Repetir e Elaborar. Op. cit., p. 166.

${ }^{94}$ Freud, Sigmund. (1915) Observações Sobre o Amor Transferencial. Obras Psicológicas Completas de Sigmund Freud, vol. XII, Rio de Janeiro, Imago, 1988, p. 177.

95 Freud, Sigmund. (1915) Observações Sobre o Amor Transferencial. Obras Psicológicas Completas de Sigmund Freud, vol. XII, Rio de Janeiro, Imago, 1988, p. 186.
} 
Podemos nos perguntar como pode tal amor constituir-se numa resistência.

Na concepção freudiana, ao submeter-se à associação-livre, o paciente é levado a admitir ou a recordar lembranças aflitivas e, por isso, reprimidas de sua história. Dirigindo seu amor ao analista, afasta-o de sua posição, desviando seu interesse pelo trabalho associativo.

É possível, a partir daí, que desacreditemos da veracidade desse amor. Contudo, Freud nos alerta sobre seus aspectos distintos e semelhantes em relação ao amor que encontramos na vida comum.

A particularidade do amor transferencial repousa na manifestação da resistência. Entretanto, a resistência não cria esse amor, mas o manipula. Assim, o amor que está dentro e o que está fora da situação analítica assemelham-se no sentido de que são o mesmo em suas origens: "É verdade que o amor consiste em novas edições de antigas características e que ele repete reações infantis. Mas este é o caráter essencial de todo estado amoroso. Não existe estado deste tipo que não reproduza protótipos infantis. É precisamente desta determinação infantil que ele recebe seu caráter compulsivo, beirando, como o faz, o patológico."96

Ciente disto, o analista não deve atribuir esse amor aos seus próprios encantos, nem corresponder a ele como tal (a não ser que arque com a interrupção da análise $)^{97}$, ao mesmo tempo que não deve destruí-lo, ou instigar o analisando a renunciá-lo, assumindo, por exemplo, uma posição moralista. Deve, ao mesmo tempo que conserva a abstinência no tratamento, impedindo a satisfação real, tomar a transferência como o motor próprio do trabalho analítico: “...fixarei como princípio fundamental que se deve permitir que a necessidade e anseio da paciente nela persistam, a fim de poderem servir de forças que a incitem a trabalhar e efetuar mudanças, e que devemos cuidar de apaziguar estas forças por meio de substitutos." 98

No que se refere à contratransferência, Freud diz sobre a necessidade de controlá-la em prol de se manter a neutralidade na análise. Evidente que, se lembrarmos que o que desencadeou a transferência no analisando foi exatamente a presença do analista, devemos cuidar de ressaltar que não se trata da pessoa do analista, mas da função que ocupa no tratamento, da posição de quem supostamente sabe sobre aquilo que aflige o paciente. Porém, sabendo que por trás do analista existe uma pessoa com

\footnotetext{
${ }^{96}$ Idem, p. 185.

${ }^{97}$ Freud escreve sobre o resultado dessa retribuição do amor transferencial, deixa claro que apenas o paciente encontraria seu objetivo, pois atuaria, ao invés de trabalhar suas lembranças. Idem, p. 183.

${ }^{98}$ Idem, p. 182.
} 
seu universo psíquico, algo dessa relação com o paciente deve desencadear sua cadeia de representações. Freud já havia tratado disso em 1910, num congresso em Nurembergue: “Tornamo-nos cientes da 'contratransferência' que, nele, surge como resultado da influência do paciente sobre os seus sentimentos inconscientes e estamos quase inclinados a insistir que ele reconhecerá a contratransferência, em si mesmo, e a sobrepujará." 99

O lugar primordial que a transferência passou a ocupar na condução da análise, deixando de ser a recordação do conteúdo recalcado o aspecto relevante, mas sua revivescência, a reedição dos afetos na figura do analista, sob forma de uma nova neurose - a neurose de transferência ${ }^{100}$ - remete-nos a uma discussão bastante polêmica dentro da psicanálise: a auto-análise.

Num primeiro momento, Freud indica a auto-análise aos analistas a fim de poderem controlar a contratransferência: (...) "nenhum psicanalista avança além do quanto permitem seus próprios complexos e resistências internas; e, em consequiência, requeremos que ele deva iniciar sua atividade por uma auto-análise e levá-la, de modo contínuo, cada vez mais profundamente, enquanto esteja realizando suas observações sobre seus pacientes." ${ }^{101}$ Além disso, acreditou ter-se submetido, ele próprio, à autoanálise no período das correspondências com Fliess (com a análise de alguns sonhos, por exemplo). Entretanto, já apresentava indícios de uma posição crítica em relação à sua validade: "Minha auto-análise continua interrompida. Apercebi-me da razão por que só posso me analisar com o auxílio de conhecimentos objetivamente adquiridos (como uma pessoa de fora). A verdadeira auto-análise é impossível, caso contrário, não haveria

\footnotetext{
${ }^{99}$ Freud, Sigmund. (1910b) As Perspectivas Futuras da Terapêutica Psicanalítica. Obras Psicológicas Completas de Sigmund Freud, vol. XI, Rio de Janeiro, Imago, 1970, p. 130.

100 "Quando a transferência atingiu esse grau de importância, o trabalho com as recordações do paciente retira-se bem para o fundo da cena. Em conseqüência, não é incorreto dizer que já não mais nos ocupamos da doença anterior do paciente, e sim de uma neurose recentemente criada e transformada, que assumiu o lugar da anterior. (...) Todos os sintomas do paciente abandonam seu significado original e assumem um novo sentido que se refere à transferência." Freud, Sigmund. "Teoria Geral das Neuroses Conferência XXVII Transferência". In (1917) Conferências Introdutórias Sobre Psicanálise. Obras Psicológicas Completas de Sigmund Freud, vol. XVI, Rio de Janeiro, Imago, 1976, p. 517-518.

${ }^{101}$ Idem, p. 130.
} 
doença [neurótica]. Visto que ainda estou lutando com uma espécie de enigma em meus pacientes, isso está fadado a me deter também em minha auto-análise."102

Se ocorreu um "movimento" no sentido analítico, durante o período em que Freud se relacionou com Fliess, foi, sem dúvida, devido à posição que este último ocupava nessa relação e que, como vimos anteriormente, se assemelhava à posição do analista. Assim como o analista ocupa a posição de alguém em quem se supõe um saber sobre a doença de seu paciente, Fliess era colocado por Freud, de certa forma, nessa mesma posição, ao supervalorizar o saber que o colega detinha.

Em seus últimos trabalhos, Freud deixa clara a limitação da auto-análise, tendo em vista a ação da resistência: "Na auto-análise, porém, o perigo de fazer coisas incompletas é muito grande. Pode-se, com muita facilidade, ficar satisfeito com uma explicação parcial, atrás da qual a resistência facilmente pode estar ocultando algo que talvez seja mais importante." ${ }^{103}$ Passa a recomendar aos analistas a análise didática (conduzida por outro analista).

A análise, segundo a entendemos, consiste na instalação da neurose de transferência e na sua resolução através da interpretação e elaboração. Como nos diz Freud, "são precisamente eles [os fenômenos transferenciais] que nos prestam o inestimável serviço de tornar imediatos e manifestos os impulsos eróticos ocultos e esquecidos do paciente." ${ }^{104}$. Portanto, é possível concluir que não existe análise sem transferência, isto é, na análise é imprescindível a existência de um outro sobre o qual se atualiza o conteúdo recalcado, uma vez que, estando recalcado, não há acesso pela rememoração imediata, mas sim pela repetição. Daí a afirmação sobre a limitação da auto-análise.

Para finalizarmos essa parte do trabalho, recorreremos a um texto publicado em 1920, Além do Princípio de Prazer, que nos auxiliará na compreensão da transferência como um fenômeno que não se limita à situação analítica, mas que se encontra presente na vida comum, nas relações entre as pessoas de um modo geral.

\footnotetext{
102 Carta de 14 de novembro de 1897. In Masson, J.F. (org.) Correspondências Completas de Sigmund Freud e Wilhelm Fliess - 1887-1904. Rio de Janeiro, Imago, 1986, p. 282.

${ }^{103}$ Freud, Sigmund. (1935b) As Sutilezas de Um Ato Falho. Obras Psicológicas Completas de Sigmund Freud, vol. XXII, Rio de Janeiro, Imago, 1994, pp. 231-232.

${ }^{104}$ Freud, Sigmund. (1912) A Dinâmica da Transferência. Obras Psicológicas Completas de Sigmund Freud, Rio de Janeiro, Imago, 1970, p. 119.
} 
Cabe lembrar que se encontram nesse texto profundas reflexões sobre novos conceitos extremamente importantes para a teoria; porém, não temos a intenção de abrangê-los na sua totalidade; extrairemos deles apenas alguns aspectos que se encontram mais diretamente ligados à nossa discussão.

No desenvolvimento da teoria psicanalítica fica aparente uma suposição sobre um "movimento" do aparelho psíquico que o direciona para a redução da tensão, portanto, regido por um princípio que pode ser chamado de "princípio de prazer". Isso explica a "intenção" de se manter recalcado todo conteúdo que, no momento de sua emergência, tenha causado tensão (aflição).

Mas, se a repetição evoca o conteúdo reprimido (causador de tensão), como considerá-la fruto do princípio de prazer? Freud esclarece tal impasse a partir da origem da resistência. O conteúdo reprimido não oferece resistência alguma ao tratamento; na verdade, ele se esforça em irromper. Sua descarga, portanto, traria a satisfação a um dos "sistemas psíquicos", o inconsciente, sendo este responsável, então, pela compulsão à repetição.

Por outro lado, a compulsão à repetição traz desprazer a outro sistema, o ego, que por sua vez é responsável pelas resistências. "Não há dúvida de que a resistência do ego consciente e inconsciente funciona sob a influência do princípio de prazer; ela busca evitar o desprazer que seria produzido pela liberação do reprimido." "105 Portanto, repetição e resistência são dois mecanismos que produzem, separadamente e em oposição, satisfação para um sistema e desprazer para outro.

A vida psíquica dos indivíduos pode ser considerada uma sucessão de satisfação e desprazer. Existe, desde o florescimento da vida sexual infantil, nas relações estabelecidas com os pais e com a realidade em geral, um impedimento da satisfação de desejos que se apresentam incompatíveis com as circunstâncias. Destacamos, dentre as expe-riências que compõem a vida dos indivíduos em geral, o período fundamental na constituição da vida psíquica, classificado como Complexo de Édipo, em que a criança, desejando formar uma célula narcísica (fantasia de "completude, de satisfação eterna") com a mãe, é impedida nesse investimento à medida que o pai surge como interceptor, isto é, introduzindo nessa relação mãe-criança aquilo que Freud chamou de princípio da realidade. Se, por um lado, o impedimento da realização do desejo da criança lhe impõe a frustração (o desprazer), possibilita-lhe ingressar nos princípios que regem a vida na

\footnotetext{
${ }^{105}$ Freud, Sigmund. (1920) Além do Princípio de Prazer. Obras Psicológicas Completas de Sigmund Freud, vol. XVIII, Rio de Janeiro, Imago, 1988, p. 31.
} 
sociedade. Essa discussão encontra-se ampliada nas contribuições de Lacan quando trata de compreender a questão da constituição do sujeito, da qual logo estaremos nos ocupando.

As situações penosas são revividas pelos pacientes em análise e podem ser manifestadas pela intenção de provocar a interrupção do tratamento (como fez Dora), ou, imaginando-se desprezados pelo analista, os pacientes apresentam ciúme do mesmo, entre outras atuações. "O que a psicanálise revela nos fenômenos de transferência dos neuróticos também pode ser observado nas vidas de certas pessoas normais." "106 Assim, as pessoas de um modo geral reproduzem, nas relações sucessivas, as primeiras experiências. Freud nos dá alguns exemplos dessas repetições: (...) “o homem que, repetidas vezes, no decorrer da vida, eleva outrem a uma posição de grande autoridade e a substitui por outra nova; ou ainda, o amante cujos casos amorosos com mulheres atravessam as mesmas fases e chegam à mesma conclusão." 107 São também expressões da repetição (expressões indiretas do desejo reprimido): os sonhos, presentes na vida mental de todos os indivíduos, e o ato de brincar, característica comum da vida infantil.

Se entendemos a transferência como a "atualização da realidade do inconsciente" (expressão criada por Lacan), isto é, um fenômeno que se forma a partir da impossibilidade de tradução direta dos desejos recalcados, manifestos na "revivescência" oferecida pela compulsão à repetição, podemos reconhecê-la como elemento inerente ao trabalho psíquico. Por isso, não constitui um privilégio da relação analítica, isto é, a situação analítica não cria a transferência, apenas a reedita nessa nova situação, como podemos confirmar nas palavras de Lacan: "Mesmo se devemos considerar a transferência como um produto da situação analítica, podemos dizer que esta situação não poderia criar o fenômeno todo, e que, para produzi-lo, é preciso que haja, fora dela, possibilidades já presentes às quais ela dará composição, talvez única."108

A transferência que ocorre na vida comum não é diferente daquela da análise, porém, nesta última, a situação em que se encontram analista e analisando, diante daquilo que é proposto pelo primeiro ao outro, a associação-livre, ocorre uma "intensificação" da transferência causada pela resistência.

\footnotetext{
${ }^{106}$ Idem, p. 32.

107 Freud, Sigmund. (1920) Além do Princípio de Prazer. Obras Psicológicas Completas de Sigmund Freud, vol. XVIII, Rio de Janeiro, Imago, 1988, p. 33.

${ }^{108}$ Lacan, Jacques. “A Transferência e a Pulsão - Presença do Analista”. In O Seminário, livro 11: Os Quatro Conceitos Fundamentais da Psicanálise. Rio de Janeiro, Jorge Zahar Editor, 1998, p. 120.
} 
Concluímos que a repetição presente no tratamento analítico também se manifesta nos diferentes relacionamentos que ocupam a vida dos indivíduos: entre médico-paciente, professor-aluno, padre-penitente etc. Isto não quer dizer que tais relações não sejam efetivamente vividas e sejam apenas repetidas literalmente (repetições do vivido com os progenitores); são, na verdade, equivalentes simbólicos do que é transferido, a saber, a realidade psíquica, o desejo inconsciente. 


\section{O CONTEXTO LACANIANO}

No início deste texto referimo-nos à definição que Lacan faz de seu trabalho: um "retorno a Freud"109. Isto que Lacan pretende surge como uma oposição ao que ele considerou como distorções das proposições freudianas, transformadas em versões psicologistas, culturalistas e biologistas, entre outras. Uma das passagens em que emite sua crítica às distorções da Psicanálise é esta: "Ao que se acrescenta uma forma mental muito autóctone que, sob o nome de behaviorismo, domina de tal modo a noção psicológica na América, que está claro que recobriu a partir de então completamente na psicanálise a inspiração freudiana."

Devemos, então, compreender os problemas teóricos da Psicanálise que Lacan nos aponta e suas respectivas propostas de solução.

Conhecemos a marca fundamental da Psicanálise: a descoberta da sobredeterminação inconsciente do agir humano. Podemos dizer que o inconsciente representa o núcleo em torno do qual gira a Psicanálise, portanto, toda a teoria constitui uma tentativa de compreender a formação deste inconsciente.

O conceito de inconsciente sofreu algumas modificações no interior da teoria: foi tratado, primeiramente, como oposição aos sistemas pré-consciente/consciente e depósito de material recalcado por estes sistemas (características da chamada primeira tópica); e, posteriormente, surge sob duas características opostas, como o próprio plano em que ocorrem as defesas (segunda tópica), isto é, uma parte do ego que tende a manter o material recalcado, e outra, como sendo esse mesmo material recalcado, e que "força" sua liberação.

O conceito de inconsciente carrega em si um caráter obscuro. Isso parece ter levado Freud a trabalhar principalmente com a análise de suas manifestações: nos

\footnotetext{
109 "Não poderíamos fazer coisa melhor para este fim do que retornar à obra de Freud. Não basta dizer-se técnico para se autorizar, porque não se compreende um Freud III, recusá-lo em nome de um Freud II que se acredita compreender, e a ignorância mesma em que se está de Freud I, não desculpa que se considere as cinco psicanálises como uma série de casos tão mal escolhidos quanto mal expostos, mesmo que se devesse ficar perplexo de que o grão de verdade que elas continham se tenha salvado." Lacan, Jacques. Escritos, São Paulo, Editora Perspectiva, 1978, pp. 131-132.

${ }^{110}$ Idem, p. 110.
} 
sonhos, nos sintomas, nos lapsos, enfim, onde sua existência era (re)conhecida. Lacan nos diz: "Freud fica siderado por esses fenômenos, e é neles que vai procurar o inconsciente. (...) A descontinuidade, esta então a forma essencial com que nos aparece de saída o inconsciente como fenômeno - a descontinuidade, na qual alguma coisa se manifesta como vacilação." "111

As limitações presentes na formulação do conceito de inconsciente pela teoria freudiana são, segundo Lacan, atualmente solucionadas por novas construções científicas, mais especificamente pelo conhecimento produzido pela lingüística. "Hoje em dia, no tempo histórico em que estamos, de formação de uma ciência, que podemos qualificar de humana, mas que é preciso distinguir bem de qualquer psicossociologia, isto é, a lingüística, cujo modelo é o jogo combinatório operando em sua espontaneidade, sozinho, de maneira pré-subjetiva - é esta estrutura que dá seu estatuto ao inconsciente. É ela, em cada caso, que nos garante que há sob o termo inconsciente algo de qualificável, de acessível, de objetivável."112

Lacan, portanto, propõe uma nova abordagem (considerada por alguns autores como uma posição estruturalista) do conceito de inconsciente, a saber, o inconsciente estruturado como uma linguagem, em oposição ao estudo do inconsciente pelos fenômenos que este produz.

\section{A Formação Lingüística do Inconsciente - A Constituição do Sujeito}

Lembremos que Freud admite existir um sentido que leva o homem a agir e a viver, sem que possa conhecer suas razões. Este fato é, por ele, atribuído às determinações inconscientes. E foi a busca da "causa" dessas determinações inconscientes que conduziu Lacan à adoção dos modelos da lingüística.

Dentre os estudos que mais contribuíram para as formulações de Lacan estão as pesquisas desenvolvidas por seu amigo, o antropólogo Claude Lévi-Strauss, que investigou as proibições e as prescrições (as matrimoniais, por exemplo), enfim, a questão das leis nas sociedades primitivas. Ele nos esclarece que é compreensível o fato

\footnotetext{
111 Lacan, Jacques. "O Inconsciente e a Repetição - O Inconsciente Freudiano e o Nosso". In $O$ Seminário, livro 11: Os Quatro Conceitos Fundamentais da Psicanálise. Op. cit., p. 30.

${ }^{112}$ Idem, p. 26.
} 
de o índio não conseguir explicar o que determina as regras de seu sistema de parentesco, pois ele apenas as vive sem tê-las inventado. ${ }^{113}$

Lacan refere-se várias vezes a Lévi-Strauss em sua obra. ${ }^{114} \mathrm{E}$, a partir desses estudos, traça um paralelo: a criança e o índio não são capazes de justificar as leis que os regem, assim como o neurótico não é capaz de explicar seus rituais. Segundo Lacan, eles são habitados pelo significante, não participaram de sua criação. Esse pressuposto direciona uma investigação sobre a função da linguagem na constituição do sujeito.

Cabe chamar a atenção para esse novo conceito - sujeito - que se diferencia do conceito indivíduo até agora empregado. A teoria que se desenvolveu a partir das formulações lacanianas aponta para uma "posição" daquele que as ciências humanas se propõem estudar, isto é, este “ente” está submetido, portanto, sujeito, às leis que imperam na sociedade e que organizam, ou melhor, estruturam um sistema de linguagem que, por sua vez, constitui o inconsciente. Enfim, sujeito da linguagem, sujeito do inconsciente.

Precisamos, neste momento, procurar esmiuçar essas formulações, a fim de torná-las mais claras.

A estrutura da linguagem preexiste à entrada do sujeito no momento em que ele se desenvolve. Quando o sujeito nasce "encontra" seu "lugar" já inscrito, mesmo que seja, aparentemente, apenas sob forma de seu nome próprio. ${ }^{115}$ Leandro de Lajonquière retoma a condição da entrada do sujeito no mundo: "Não só antes de falar e de caminhar, mas antes mesmo de nascer empiricamente à vida, o sujeito já é objeto do discurso, do desejo e das fantasias de seus genitores que, por sua vez, são sujeitos assujeitados às estruturas lingüísticas, psicanalíticas e histórico-sociais."

Dizemos que a estrutura de linguagem, que constitui o inconsciente, integra uma lei: a força do significante. Miller procura esclarecer tal força do significante: (...) "é um equívoco pensar que o significante está aí a serviço do significado, e que está aí para que a gente possa dizer as coisas que tem em mente, tal como se quer dizê-las. Sempre há um intervalo entre o falar e o querer dizer. A tese de Lacan é que o significado é um efeito do significante, e que os efeitos de significado são criados pelas permutações, os

\footnotetext{
${ }^{113}$ Lévi-Strauss, Claude. As Estruturas Elementares do Parentesco. Petrópolis, Ed. Vozes, 1976.

${ }^{114}$ Exemplos de citação: Lacan, Jacques. Escritos. Op. cit., p. 143; Seminário, livro 11: Os Quatro Conceitos Fundamentais da Psicanálise. Rio de Janeiro, Jorge Zahar Editor, 1998, p. 10.

${ }^{115}$ Lacan, Jacques. "A Instância da Letra no Inconsciente ou a Razão desde Freud”. In Escritos. Op. cit., pp. $225-226$.

${ }^{116}$ Lajonquière, Leandro de. "Desenvolvimento ou Constituição do Sujeito (do Desejo): This Is The Question!". In De Piaget a Freud: Para Repensar as Aprendizagens. A (Psico)Pedagogia Entre o Conhecimento e o Saber. Petrópolis, Vozes, 1992, p. 151.
} 
jogos do significante. $O$ sentido surge, fundamentalmente, da substituição de um significante por outro." 117

A fim de nos mostrar como tudo isso "funciona", Lacan constrói operações lingüísticas que representam os mecanismos do inconsciente e a formação do sintoma neurótico. O esquema básico dessas operações é o algoritmo que formaliza a "posição" do significante e do significado ${ }^{118}: \mathbf{S} / \mathbf{s}$. Nesse esquema, $\mathbf{S}$ corresponde ao significante e s ao significado, portanto, o significante sobre o significado. A barra que os separa possui uma importância particular: indica uma resistência à significação. Isto quer dizer que o significante não responde à função de representar o significado, da maneira que é comum acreditar. Não há paralelismo entre significante e significado, à medida que o significante se compõe conforme as leis de uma ordem fechada, isto é, cada significante remete a outro significante, formando o que Lacan chamou de "cadeia significante". 119

A "cadeia significante" tem uma função primordial no emprego que o sujeito faz de sua língua. "O que essa estrutura da cadeia significante descobre é a possibilidade que eu tenho - justamente à medida que sua língua é comum a mim e a outros sujeitos, isto é, à medida que essa língua existe, - de me servir dela para significar algo totalmente diferente do que ela diz. Função mais digna de ser sublinhada na fala que a de disfarçar o pensamento (a maioria das vezes, indefinível) do sujeito: a saber, a função de indicar o lugar desse sujeito na busca da verdade."120

Lacan utilizou as figuras de linguagem, a metáfora e a metonímia ${ }^{121}$, para explicar os mecanismos descritos por Freud como condensação e deslocamento, mecanismos estes presentes na exposição anterior, que possibilitam a expressão indireta do desejo. ${ }^{122}$ Assim, a metáfora, que se refere à substituição de um termo por outro, corresponde à condensação; e a metonímia, que consiste em se referir a um objeto por uma parte sua, a parte tomada pelo todo, corresponde ao deslocamento. A linguagem

\footnotetext{
${ }^{117}$ Miller, Jacques-Alain. Percurso de Lacan: Uma Introdução. Op. cit., p. 31.

${ }^{118}$ Lacan, Jacques. "A Instância da Letra no Inconsciente ou a Razão Desde Freud". In Escritos. Op. cit., p. 227.

${ }_{119}$ Encontramos uma exposição completa sobre esse esquema no texto "A Instância da Letra no Inconsciente e a Razão Desde Freud". In Escritos. Op. cit., pp. 227-231.

${ }^{120}$ Idem, p. 235.

121 'Metáfora - A palavra significa 'transposição'. Consiste no uso de uma palavra ou expressão em outro sentido que não o próprio. Fundamenta-se na semelhança entre coisas ou fatos. A metáfora é sempre uma imagem, isto é, a representação mental de uma realidade sensível." "É a mudança de nome. Diante de um fato ou coisa, atentamos mais para uma circunstância que se relaciona com esse fato ou coisa e passamos a designá-los pela palavra ou expressão que designa a circunstância.” Quadros, Jânio. Curso Prático da Língua Portuguesa e sua Literatura - Estilística. São Paulo, Editora Formar Ltda, 1966, vol. IV, pp. 135142.

${ }^{122}$ Lacan, Jacques. “A Instância da Letra no Inconsciente e a Razão Desde Freud”. In Escritos. Op. cit., p. 246.
} 
veicula estas operações, onde o desejo inconsciente se expressa à medida que o sentido desliza.

\section{O Desejo: Motor do Psiquismo}

Podemos nos perguntar sobre a natureza desse desejo inconsciente, e chegaremos à noção de falta: quem deseja algo é porque algo lhe falta. $\mathrm{O}$ desejo surge da diferença entre aquilo que se procura e aquilo que se obtém. Assim, no bebê, a satisfação que lhe causou a primeira alimentação (que vem resolver uma condição, no princípio, inominável: a fome) não poderá se repetir, pois quem atende à sua demanda nunca o faz na mesma medida. E essa "diferença” existirá nas experiências sucessivas.

Podemos pensar, também, que o desejo indica um impedimento a uma realização; um "não" instituído; estaremos, então, pensando nas leis que regem (organizam, tornam possível) a convivência humana, nos limites que se impõem aos impulsos primitivos. Assim como a proibição do incesto, que se acredita (tomamos as contribuições de Lévi-Strauss) ter introduzido o primata na cultura. A partir daí, o ato da concepção passou do mérito aleatório para o legalizado, dando-lhe outro sentido. É desse mundo regido por leis que falávamos quando nos referimos às observações de Lacan sobre a criança e o índio. Portanto, a satisfação do desejo encontra-se impedida desde antes da primeira alimentação do bebê, ou melhor, desde antes da sua concepção, pois esse impedimento, podemos dizer, é inerente ao discurso social em que os progenitores (e seus ascendentes) se encontram assujeitados.

Lembremos que, sendo um ser totalmente dependente nas questões mais básicas de sobrevivência, o bebê encontra na mãe (ou no adulto que lhe supre as necessidades) a fonte de sua satisfação, a promessa da realização permanente, ainda que guarde sempre tal diferença. Além disso, não encontra distinção entre eles, já que não se reconhece como um ser, não há "identidade" nesse momento. Portanto, não é estranho que queira manter esta conjunção, formando uma "célula" (chamamos "célula narcísica", já que supõe uma completude). Por outro lado, se o mundo em que esta criança se encontra está regido pelas normas que anteriormente apontamos (e é o que se espera; caso contrário, entramos no campo da psicose), este adulto que a atende não poderá conservar seu olhar voltado apenas para ela. Este redirecionamento do olhar do adulto 
para um outro irá indicar a sua própria incompletude, ao mesmo tempo que vai marcando para este bebê o seu lugar como um, sua "identidade".

Freud elaborou a teoria do Complexo de Édipo que, na verdade, é uma metáfora utilizada para simbolizar o registro da castração como a marca instituída pela proibição do incesto, incesto que pretende a perpetuação da completude. Segundo Franklin Goldgrub: "Para Freud, a força da proibição só pode denunciar a existência de um desejo proporcional em sentido contrário. Lévi-Strauss, por sua vez, assinala as vantagens sociais propiciadas pela exogamia, comparando os três regimes elementares de conjugalidade caracterizados por diferentes graus de distância em relação ao marco zero da endogamia." ${ }^{23}$ O complexo de castração não é um registro de um acontecimento passível de verificação na história da civilização, todavia ele se repete na experiência de vida de cada sujeito. E, na tentativa de localizar uma possível origem histórica da proibição do incesto, o fator que leva à condenação consciente do mesmo, Freud consegue explicar como pode o incesto ser inconscientemente desejado. ${ }^{124}$

Encontramos na teoria do estágio do espelho, formulada por Lacan, a representação da constituição do sujeito, por sua entrada no mundo regido pela linguagem, à medida que, procurando ser o próprio desejo materno, se espelha no olhar da mãe, e desta forma, identifica-se com essa(s) imagem(s) que indica um lugar numa história constituída por uma série de desejos expressos nas palavras, no nome, nas comparações com familiares (avós, tios etc.), enfim, inscreve o sujeito numa rede de relações simbólicas, seu "reconhecimento" imaginário. Contudo, cada outro é um novo espelho para que o sujeito se "ajuste" (cada outro é outro sujeito do desejo), e isto levará à constante procura do reconhecimento. "Para dizer tudo, em nenhum lugar aparece mais claramente que o desejo do homem encontra seu sentido no desejo do outro, não tanto porque o outro detém as chaves do objeto desejado, quanto porque seu primeiro objeto é de ser reconhecido pelo outro."125

Esta permanente incompletude (ou completude perdida, para sempre, da célula narcísica), a impossibilidade de satisfação, isto que desde sempre resta da diferença entre as experiências (lembremos da fome no bebê), a eterna busca do reconhecimento, a procura de fazer-se amar, tornar-se amável pelo Ideal do Ego, procurando constituir-se

\footnotetext{
${ }^{123}$ Goldgrub, Franklin. Mito e Fantasia: O Imaginário segundo Lévi-Strauss e Freud. São Paulo, Ed. Ática, 1995, pp. 23-24.

${ }^{124}$ Idem, pp. 24-26.

${ }^{125}$ Lacan, Jacques. "Função e Campo da Fala e da Linguagem em Psicanálise - Símbolo e Linguagem como Estrutura e Limite do Campo Psicanalítico". In Escritos. Op. cit., p. 132.
} 
no Ego Ideal, isto que falta para que o sujeito triunfe, Lacan chama de objeto (pequeno) a. O "objeto $a$ " é o elemento causa do desejo do sujeito, é o ponto de falta onde o sujeito tem de se reconhecer, e se tornou um conceito tão central na teoria de Lacan quanto o conceito de inconsciente na teoria de Freud. É o objeto a que faz o sujeito "apostar" na transferência.

Se temos o desejo como motor do psiquismo, e este, como um sistema significante (linguagem), dizemos que o discurso que constitui o sujeito é uma seqüência de significantes, que se dirige inconscientemente a um outro, que Lacan chama de o (grande) Outro: "Se eu digo que o inconsciente é o discurso do Outro com O maiúsculo, é para indicar o para além onde se prende o reconhecimento do desejo ao desejo de reconhecimento." ${ }^{126}$ Podemos dizer que aquilo que é dito é, ao mesmo tempo, algo diferente do que conscientemente é intencionado; portanto, o sujeito desconhece o sentido do que diz, pois o inconsciente carrega um saber do qual o sujeito nada sabe. Isto indica que, quando nos referimos ao inconsciente, conseqüentemente nos remetemos a uma já formada rede de significantes, e é neste sentido que dizemos da existência de um saber. Em outras palavras, o sujeito encaminha inconscientemente seu discurso a um outro, o Grande Outro, que dá o verdadeiro sentido ao discurso. Assim, o sujeito é surpreendido porque sempre diz mais ou menos do que intencionava dizer, isso indica que o inconsciente, estruturado como uma linguagem, guarda um saber do qual o sujeito nada sabe.

Com esta rápida exposição do pensamento de Lacan, tentamos deixar clara a natureza daquilo que chamamos no início de novo posicionamento proposto pela leitura lacaniana, pois nos apresenta a concepção de inconsciente como uma linguagem estruturada.

Diante disso, não poderíamos deixar de abordar o desenvolvimento teórico do conceito de transferência, resultante da leitura que Lacan fez dos textos freudianos. A importância reside no fato de o conceito de transferência deixar de ser concebido do ponto de vista fenomenológico, de suas manifestações, para ser abordado enquanto estrutura da linguagem.

\footnotetext{
${ }^{126}$ Lacan, Jacques. “A Instância da Letra no Inconsciente e a Razão desde Freud”. In Escritos. Op. cit, p. 255.
} 


\section{O Conceito de Transferência em Lacan}

Devemos lembrar que Freud atribuiu algumas características à transferência: repetição dos protótipos infantis; repetição considerada uma resistência ao tratamento analítico; depois, condição à submissão (sugestão) a esse trabalho; e nova formação de sintomas, isto é, a neurose de transferência.

Podemos antecipar a compreensão da mudança do referencial de Lacan, na teoria da transferência, se considerarmos que, resistência, repetição e sintoma (neurose de transferência) são fenômenos resultantes da transferência, enquanto o Sujeito Suposto Saber, que logo veremos, consiste no elemento de estrutura da mesma. Portanto, é o Sujeito Suposto Saber que constitui tais fenômenos característicos da transferência.

Em primeiro lugar, tomemos como referência a experiência analítica, por se tratar de uma situação onde essas características se encontram em evidência. Nela, uma condição é imposta à relação: que o analisante "obedeça" uma regra fundamental que é a associação-livre, levando a supor que, diga o que disser, sempre será dito algo que obedece uma causa. Daí surge uma nova perspectiva da resistência, a saber, não é a transferência o dispositivo que a aciona, mas aquilo que, mesmo presente no discurso, resiste à fala, a barra do algoritmo $\mathrm{S} / \mathrm{s}$ que resiste à significação, aquilo que sabemos intransponível: o saber inconsciente.

Para Lacan, a transferência é uma conseqüência da estrutura da relação analítica, e não pode ser apenas entendida como simples repetição ou atualização, mas uma atualização afetada pela presença real do analista, isto é, produzida num momento dialético, que também não pode ser confundido com a idéia da Psicologia sobre a intersubjetividade: "Quando se invoca a intersubjetividade, a ênfase é posta no fato de que, este outro, devemos reconhecer nele um sujeito como nós." ${ }^{127}$ Lacan considera a transferência um fenômeno subjetivo. Isto quer dizer que, nessa "relação", a subjetividade de cada um é única, portanto, não guarda semelhanças, não há simetria entre os desejos dos sujeitos em questão, mas sim disparidades (o sujeito não pode ser representado por outro sujeito, mas por um significante). Por isso, pode-se dizer que não há relação propriamente dita.

\footnotetext{
${ }^{127}$ Lacan, Jacques. “A Psicologia do Rico”. In O Seminário, livro 8: A Transferência 1960-1961. Rio de Janeiro, Jorge Zahar Ed., 1992, p. 58.
} 
A discussão sobre o amor, abordada por Freud no texto Observações Sobre o Amor de Transferência, é retomada por Lacan que, em $O$ Seminário 8, de forma bastante ampla e profunda, analisa o desenvolvimento do conhecido Banquete de Platão. Este texto favorece a compreensão das posições que os sujeitos ocupam na "relação" transferencial (basicamente, amante e amado).

Valemos da reconstituição de $O$ Banquete por Hector Benoit: "Conhecemos os detalhes deste banquete graças a Aristodemo que lá esteve e que posteriormente narrou aqueles acontecimentos a Apolodoro; deste último, a narração provavelmente chegou a Platão, que escreveu o célebre diálogo O Banquete."128 Agatão, que acabara de vencer num festival poético, oferece, em comemoração, um jantar para os amigos. Após o jantar, Erixímaco propõe que cada um dos convidados fale sobre Eros, o deus do Amor. Sócrates é o último a falar, relembrando os ensinamentos que recebeu da sacerdotisa Diotima. Ao terminar, um grande barulho indica a chegada de arruaceiros, dentre eles Alcibíades, que pede permissão para entrar na casa de Agatão, e é aceito. Logo que percebe a presença de Sócrates, Alcibíades inicia um discurso com tom de ironia, identificado por Sócrates como produto do ciúme do outro (Agatão). Daí, surge um outro discurso em que Alcibíades testemunhará a respeito da sabedoria socrática. Segue então um elogio em que Sócrates é comparado a um sileno. "Os silenos eram representados pelos escultores gregos como particularmente feios, em geral, com rosto humano, mas com cauda e cascos de bode; no entanto, essas esculturas possuíam pequenas portinholas que, quando abertas, revelavam grandes e belas surpresas: no interior dos silenos escondiam-se belas estatuetas dos deuses." 129

Assim diz Alcibíades ao referir-se a Sócrates: "Uma vez porém que fica sério e se abre, não sei se alguém já viu as estatuetas que existem lá dentro; eu já as vi uma vez, e tão divinas me pareceram, com tanto ouro, com uma beleza tão completa e tão extraordinária que eu só tinha de fazer imediatamente o que mandasse Sócrates." ${ }^{130} \mathrm{De}$ tal forma ficou fascinado que acreditou que Sócrates estivesse interessado por ele (aliás, diz-se que Alcibíades possuía uma grande beleza física). Porém, Sócrates não se rendeu

\footnotetext{
${ }^{128}$ Benoit, Hector. Sócrates: O Nascimento da Razão Negativa. São Paulo, Ed. Moderna, 1996, p. 63.

${ }^{129}$ Idem, p. 67.

${ }^{130}$ Idem, p. 67.
} 
à sua sedução e rejeitou o seu corpo. Por isso, Alcibíades apresenta-se magoado, ao proferir seu discurso.

Devemos compreender o que causou essa identificação de Alcibíades com Sócrates, tornando-o desejante do seu amor.

Sabemos que o método socrático, que recebe o nome de Razão Negativa, está apoiada numa sucessão (interminável) de questionamentos. Ao interrogar-se sobre o conhecimento das coisas, Sócrates indica não ser detentor da verdade. "Já ele próprio, Sócrates, se nada sabia, sabia ao menos que não sabia." ${ }^{131}$ Por isso, ao ter de falar sobre o amor, estabelece alguns questionamentos “O amor é ou não é amor de alguma coisa?", “Amar e desejar alguma coisa é tê-la ou não tê-la?", "Pode-se desejar o que já se tem?", em seguida, recorre ao saber, à autoridade de outro (a sacerdotisa Diotima, que lhe contou o mito sobre o nascimento do amor).

O discurso de Sócrates, então, explica-nos Lacan, não define o amor, mas produz o amor, à medida que introduz a questão da função da falta, que é constitutiva da relação de amor. O amor, para Sócrates, é o desejo de algo que não se possui e que não se encontra no plano do verbal. "Mesmo se é formulado, de saída, que as únicas coisas que Sócrates conhece bem são as coisas do amor, ele não pode, justamente, falar delas a não ser permanecendo na zona do ele não sabia. Mesmo sabendo, ele não pode falar, ele mesmo, daquilo que sabe, e deve fazer falar alguém que fala sem saber." "132 Em suma, ele só pode estar no "jogo" que constitui o amor à medida que ele não saiba e, à medida que ele se retira do jogo é porque ele sabe.

As palavras de Sócrates produzem, em Alcibíades, um estado semelhante ao de uma possessão. Este último necessita saber sobre o desejo de Sócrates, para ajustar-se a ele. Por sua vez, Sócrates recusa essa posição de possuidor de algo desejável: "Aqui onde você vê alguma coisa, eu não sou nada." Compreensão somente possível porque se retirou do "jogo do amor".

A transferência assemelha-se ao amor, podemos dizer, confunde-se com ele, pois o amante se aproxima do outro pela falta, enquanto o amado não sabe o que tem: "O que falta a um não é o que existe, escondido, no outro. Aí está todo o problema do amor."133 O amor pode ser considerado uma metáfora (um significante), já que esta consiste numa substituição. Não sabemos se aquilo que o amado possui guarda alguma semelhança

\footnotetext{
${ }^{131}$ Benoit, Hector. Sócrates: O Nascimento da Razão Negativa. São Paulo, Ed. Moderna, 1996, p. 45.

${ }^{132}$ Lacan, Jacques. "A Mola do Amor - Saída do Ultra-Mundo”. In O Seminário, livro 8: A Transferência. Op. cit., p. 133

${ }^{133}$ Lacan, Jacques. "A Psicologia do Rico". Op. cit., p. 46.
} 
com o que falta ao amante. Assim, é justamente na recusa de ser o objeto amado (de ser e/ou possuir o ágalma, essa alguma coisa visada pelo desejo) que Sócrates mantém o desejo de Alcibíades, porque lhe mantém a falta.

Estruturalmente, o sujeito do inconsciente procura, amando o analista, colocá-lo no lugar de Ideal do Ego e busca constituir-se, ele próprio, no lugar de Ego Ideal. Nesse sentido, o paciente procura restaurar uma situação especular (referimo-nos ao estágio do espelho), uma vez que a identificação é procurada por meio do fazer-se amar, tornar-se amável pelo Ideal do Ego. Identificamo-nos com aquele a quem demandamos alguma coisa através do "pedido" de amor. Lacan nos diz sobre o engano inerente a esse pedido: "Que maneira melhor de se garantir, sobre o ponto em que nos enganamos, do que persuadir o outro da verdade do que lhe adiantamos! Não está aí uma estrutura fundamental da dimensão do amor que a transferência nos dá a ocasião de imajar? Ao persuadir o outro de que ele tem o que nos pode completar, nós nos garantimos de poder continuar a desconhecer precisamente aquilo que nos falta." 134

O analisante, convidado a falar livremente (sem impor censura), supõe no analista um saber sobre aquilo que desencadeou seu sintoma, um saber sobre seu saber inconsciente, portanto, sobre aquilo que lhe falta, isto que o atormenta e que se constitui intransponível em seu discurso. Busca a verdade sobre seu desejo, a verdade sobre aquilo que lhe é mais íntimo, endereçando sua demanda ao analista (demanda de amor, de reconhecimento), que se encontra no lugar do Outro. Do seu lado, o analista usa seu poder, atribuindo um sentido sobre o que é falado; dessa forma, determina a identidade do analisando. Esta "posição", que o analisante "atribui" ao analista, Lacan passou a chamar de Sujeito Suposto Saber, o princípio constitutivo da transferência. Em linhas gerais dizemos que a transferência é possível porque existe um sujeito que demanda e outro que é suposto saber.

Cabe destacar que o Sujeito Suposto Saber não deve ser confundido com as atitudes do paciente, em suas convicções conscientes sobre a capacidade do terapeuta (até mesmo quando expressa, conscientemente, desconfiança). Trata-se, isto sim, de uma posição estrutural, pois é o sujeito do inconsciente que supõe que o saber sobre o inconsciente (sobre seu desejo, sobre aquilo que lhe falta) está todo produzido no lugar do analista. E não se trata da pessoa do analista, mas do significante do analista.

\footnotetext{
${ }^{134}$ Lacan, Jacques. "A Transferência e a Pulsão - A Presença do Analista”. In Seminário, livro 11: Os Quatro Conceitos Fundamentais da Psicanálise. Op. cit., p. 128.
} 
Estas proposições possibilitam-nos concluir que a transferência, estruturada pela fala, pela demanda atualizada na análise, pode identificar-se com uma demanda de amor (como vimos em Freud), demanda de reconhecimento - o amor do Outro; ela produz, a partir dessa relação, um sintoma, pois este carrega uma significação que se dirige ao Outro; podemos chamar esse sintoma de neurose de transferência. Diz Miller: "Se Freud pode dizer que todos os sintomas adquirem uma nova significação a partir do começo da cura analítica, é porque o sintoma é um elemento que tem uma significação que se dirige ao Outro." 135

A posição de Outro, que o analista ocupa transitoriamente para favorecer a transferência, não deve ser assumida por ele. Isto quer dizer que, se o analista assume esta posição, estará negando a impossibilidade presente na constituição do desejo, e lhe renderá enganos importantes ao colocar-se como referência da realidade "verdadeira" (Discurso do Mestre), como super-eu, como função normatizante, que não corresponde à sua posição de analista. ${ }^{136}$ Isso quer dizer que o analista, por não se identificar com o Outro (apenas apresentando-se como suporte do Outro, o que chamamos de posição de semblante), indica a inexistência real do Sujeito Suposto Saber, reconhecendo a singularidade do sujeito, à medida que permite a expressão de seu desejo. Lacan diz que é diante da falta na análise que o paciente se aproxima de seu desejo: "Vamos ao encontro de algo que conhecemos, por já termos seriamente aproximado a topologia do que o sujeito deve encontrar na análise em lugar daquilo que procura. Se ele parte em busca do que tem e não conhece, o que vai encontrar é o que lhe falta. (...) É como aquilo que the falta que se articula o que ele vai encontrar na análise, a saber, seu desejo." ${ }^{\prime 37}$ Portanto, é não pretendendo oferecer o que lhe falta (encarnar a presença do objeto a) que o analista permite a articulação do desejo do analisando, atualizando a realidade do inconsciente, o saber inconsciente.

A contratransferência para Lacan seria, justamente, esse engano (manifesto por preconceito e ignorância) em que o analista se coloca ao encarnar o Outro, o objeto $a$, a verdade absoluta, o modelo de identificação. Portanto, quando reconhecemos no analista um outro, um sujeito do desejo, na relação transferencial, devemos guardar as distinções entre o desejo e a contratransferência, e não confundi-los.

\footnotetext{
${ }^{135}$ Miller, Jacques-Alain. Percurso de Lacan: Uma Introdução. Op. cit., p. 65.

${ }^{136}$ Esta pretensa posição de saber sobre a medida certa da realidade foi analisada por Lacan, que a denominou Discurso do Mestre, e vai nos possibilitar uma discussão sobre um dos discursos presentes na escola.

${ }^{137}$ Lacan, Jacques. “A Harmonia Médica”. In O Seminário, livro 8: A Transferência. Op. cit., p. 71.
} 
Usamos a situação analítica para elucidar a estrutura da transferência; no entanto, é-nos de extrema importância compreendê-la na vida comum, e podemos ver que ela não é diferente, a não ser pela função do analista, da proposta feita em análise.

O que nos interessa muito é saber que Lacan também não considera a transferência uma exclusividade da análise: "Cada vez que um homem fala a outro de uma maneira autêntica e plena, há no sentido próprio, transferência, transferência simbólica, alguma coisa se passa que muda a natureza dos dois seres em presença." Na comunicação, presente em toda relação humana, a interpretação que o ouvinte faz do que é dito decide não apenas sobre o sentido, mas, como Lacan nos indica, a própria identidade de quem fala. O poder do ouvinte reveza-se entre os que se comunicam.

"O fenômeno da transferência é ele próprio colocado em posição de sustentáculo da fala." ${ }^{139}$ A transferência manifesta-se na relação com alguém a quem se fala. Ela é, então, constitutiva.

O Sujeito Suposto Saber não se limita ao saber psicanalítico, nem mesmo necessita autorizar-se por alguma ciência, como nos lembra Miller ${ }^{140}$ sobre a transferência de Freud a Fliess, um médico que formulava teorias que podem ser consideradas absurdas. Aliás, Lacan discorre em A Harmonia Médica sobre as ilusões engendradas no discurso científico. Isto nos vem indicar que, assim que se estabelece uma relação, a posição de Sujeito Suposto Saber pode ser ocupada por qualquer um. Porém, a identificação com esta posição determina um discurso de domínio (Discurso do Mestre) que prende o outro numa posição de alienação. Na verdade, a alienação é um efeito sempre presente quando há o discurso do outro, mas é sucedida pela separação que permite ao desejo do sujeito manter-se no que ele tem de mais próprio.

A experiência analítica mostra-nos que a repetição constitui nossa vida, que estamos capturados por um número limitado de significantes e que o automatismo de repetição busca a temporalização da experiência da transferência.

Mas, se sabemos da impossibilidade de o outro suprir a falta do outro semelhante, o que move o sujeito para infinitas relações? É justamente esse caráter irrealizável que mantém a procura e, por outro lado, Lacan nos diz que a realização do desejo não se relaciona com nenhuma posse de objeto. Assim, tomamos o amor como

\footnotetext{
${ }^{138}$ Lacan, Jacques. O Seminário, livro 1, Os Escritos Técnicos de Freud. Rio de Janeiro, Jorge Zahar Ed., 1979, p. 130.

${ }^{139}$ Lacan, Jacques. "A Transferência no Presente". In O Seminário, livro 8: A Transferência. Op. cit., p. 175.

${ }^{140}$ Miller, Jacques-Alain. “A Transferência e o Sujeito Suposto Saber". In Percurso de Lacan: Uma Introdução. Op. cit., p. 86.
} 
fenômeno, entre todas as outras formas de relacionamento, que evidencia este permanente estado de busca da realização do desejo: "Isso faz eco o bastante àquilo através do que introduzi há pouco meu discurso referente à relação com o outro, a saber, a diferença que existe entre o objeto de nosso amor enquanto recoberto por nossas fantasias e o ser do outro, à medida que o amor fica se interrogando para saber se pode alcançá-lo." 141

${ }^{141}$ Lacan, Jacques. “A Metáfora do Amor”. In O Seminário, livro 8: A Transferência. Op. cit., p. 53. 


\section{TERCEIRO CAPÍTULO}

\section{A PSICANÁLISE, A TRANSFERÊNCIA E}

\section{A IMPOSSIBILIDADE DE RELAÇÃO}

"Não posso ser otimista e me distingo dos pessimistas unicamente porque o mal, a tolice e a loucura não me deixam fora de mim, pela simples razão de que eu já os havia, antecipadamente, incluído na estruturação do mundo." 


\section{A PSICANÁLISE, A TRANSFERÊNCIA E}

\section{A IMPOSSIBILIDADE DE RELAÇÃO}

Como já foi mencionado em diversos outros trabalhos, Freud afirmou a impossibilidade da educação, junto com outros dois ofícios: governar e curar. ${ }^{142} \mathrm{~A}$ impossibilidade indica uma característica comum entre eles, qual seja, a de que podemos saber de antemão que seus resultados serão, seguramente, sempre insatisfatórios.

Como compreender esta posição freudiana, que não poucas vezes é erroneamente interpretada como um pessimismo? Sabemos que os três ofícios supõem efeitos de uns (governante, analista e educador) sobre outros (a nação, o paciente e o educando), e também sabemos que os primeiros aspiram pelo controle dos efeitos que provocam. Qual o resultado que pretendem alcançar através do controle? Basta atentar ao fato de que as posições de governante, analista e educador prevêem um certo domínio sobre o outro, para adiantarmos uma suposição de que, a princípio, ocupam o lugar de ideal. Sendo assim, o domínio sugere uma suposta garantia de que os outros se conformem ao ideal que representam, isto é, que se tornem alguém como eles. Em

\footnotetext{
${ }^{142}$ Esta afirmação freudiana pode ser encontrada em diferentes momentos da obra psicanalítica. Dentre eles estão: Freud, Sigmund. (1925) Prefácio a Juventude Desorientada, de Aichhorn. Obras Psicológicas Completas de Sigmund Freud, vol. XIX, Rio de Janeiro, Imago, 1988, p. 307; Freud, Sigmund. (1937) Análise Terminável e Interminável. Obras Psicológicas Completas de Sigmund Freud, vol. XXIII, Rio de Janeiro, Imago, 1988, p. 265.
} 
outras palavras, o domínio levaria ao apagamento da diferença que se aninha entre uns e outros.

Entretanto, a Psicanálise mostra que, no que diz respeito aos sujeitos, não há garantias de que se possam produzir efeitos predeterminados. Isto não se deve a uma questão de ignorância científica daqueles que pretendem o domínio, mas vem nos lembrar de que, desde que aceitamos a construção da teoria psicanalítica sobre a formação e funcionamento do psiquismo humano, estamos diante da realidade do inconsciente, portanto, de uma porção incontrolável, não manipulável, dos chamados indivíduos da "relação intersubjetiva".

A "relação" na vida cotidiana, como nos atos de governar, curar e educar, está sujeita à singularidade das representações psíquicas dos envolvidos, aos seus desejos inconscientes. Assim, em linhas gerais, podemos dizer que a impossibilidade dos governos situa-se não só na pluralidade de desejos de uma população e, portanto, no impedimento de realizá-los na sua totalidade, mas também (talvez, principalmente) na supremacia dos interesses pessoais dos governantes sobre os interesses coletivos. $\mathrm{O}$ "bem" que se pretende oferecer a uma nação, antes de tudo, é o "bem" para quem governa, para onde aponta seu desejo. Inclusive podemos dizer que, de certa forma, para Freud, a tendência à corrupção não é privilégio de alguns poucos. É o que percebemos no uso que faz da afirmação do escritor Analote France, para ilustrar a crítica aos que não se vêem implicados nas suas impressões da realidade: "Tal acontecimento poderia justificar as palavras do escritor que nos adverte que, quando se dota um homem de poder, é difícil para ele não utilizá-lo mal."143

E a impossibilidade imposta à cura psicanalítica implica a discussão que Freud faz sobre o término da análise: "Nesse sentido, o que estamos indagando é se o analista exerceu uma influência de tão grande conseqüência sobre o paciente, que não se pode esperar que nenhuma mudança ulterior se realize neste, caso sua análise venha a ser continuada. É como se fosse possível, por meio da análise, chegar a um nível, ademais, em relação ao qual pudéssemos confiar em que seria capaz de permanecer estável, tal como se, talvez, tivéssemos alcançado êxito em solucionar todas as repressões do paciente e em preencher todas as lacunas em sua lembrança."144 Este caráter interminável da análise deve-se ao que a teoria já havia revelado sobre uma tendência dos indivíduos à neurose, portanto, a impossibilidade de se liqüidarem todos os

\footnotetext{
${ }^{143}$ Freud, Sigmund. (1937) Análise Terminável e Interminável. Op. cit., p. 266.

${ }^{144}$ Idem, p. 235.
} 
sintomas: "Nosso objetivo não será dissipar todas as peculiaridades do caráter humano em benefício de uma 'normalidade' esquemática, nem tampouco exigir que a pessoa que foi 'completamente analisada' não sinta paixões nem desenvolva conflitos internos. A missão da análise é garantir as melhores condições psicológicas possíveis para as funções do ego; com isso, ela se desincumbiu de sua tarefa." ${ }^{145}$ Assim, o alcance possível à análise, o que Freud está chamando de "melhores condições possíveis para as funções do ego", resume-se, até certo ponto, na substituição de sintomas.

Aproximamo-nos da questão que mais nos interessa. Compreender a natureza e a extensão da impossibilidade da educação significa dominar as proposições psicanalíticas sobre o alcance e os limites da educação diante da constituição e funcionamento do aparelho psíquico.

Evidente que, para afirmarmos sobre o caráter sempre insatisfatório dos resultados educacionais, é necessário conhecer os objetivos que a educação se propõe alcançar, bem como reconhecer uma certa alteração destes objetivos diante das mudanças nos valores educacionais ao longo da história da Educação.

Numa época mais remota, estudiosos interessados na educação, como Rousseau, ansiavam por uma educação menos repressora, assim como pudemos ver na primeira parte deste trabalho. Até certo momento de sua obra, Freud também acreditou na profilaxia das neuroses através de uma educação que não reproduzisse a moral sexual. Acreditava que uma reforma na educação poderia produzir indivíduos menos prejudicados, isto é, mais felizes. Podemos identificar isto no texto datado de 1907, $O$ Esclarecimento Sexual das Crianças: "Certamente, se a intenção dos educadores é sufocar a capacidade da criança de pensamento independente, em favor de uma pretensa 'bondade' que tanto valorizam, não poderiam escolher melhor caminho do que ludibriála em questões sexuais e intimidá-la pela religião. As naturezas mais fortes, é verdade, resistirão a tais influências e se tornarão rebeldes contra a autoridade dos pais e, mais tarde, contra qualquer outra autoridade. Se as dúvidas que as crianças levam aos mais velhos não são satisfeitas, elas continuam a atormentá-las em segredo, levando-as a procurar soluções nas quais a verdade adivinhada mescla-se da forma mais extravagante

${ }^{145}$ Idem, pp. 266-267. 
a grotescas falsidades, e a trocar entre si informações furtivas em que o sexo é apresentado como uma coisa horrível e nauseante, em conseqüência do sentimento de culpa dos jovens curiosos." 146

Porém, o próprio Freud já apresentava uma perspectiva diferente em relação às suas afirmações sobre o papel profilático da educação, à medida que já havia efetuado outras descobertas teóricas que lhe mostraram estar enganado sobre os efeitos positivos de uma educação reformada. ${ }^{147}$ Freud percebia que a moralidade não está na origem do recalque da sexualidade, portanto a moral não poderia mais ser considerada a causa das neuroses. Descobre que a origem do desprazer, que atua no recalcamento, encontra-se na própria sexualidade. São estas idéias sobre o papel secundário da moral na educação que encontramos num famoso texto intitulado Manuscrito $K$, enviado a Fliess na carta de $1^{\circ}$ de janeiro de 1896: "Em minha opinião, a produção de desprazer na vida sexual deve ter uma fonte independente: uma vez que esteja presente essa fonte, ela pode despertar sensações de repulsa, reforçar a moralidade, e assim por diante." ${ }^{148}$ Por ser a sexualidade essencialmente perturbadora, a moralidade ganha força no desenvolvimento da neurose. Mais ainda, a moralidade é uma das formas que os homens encontram para se defenderem da sexualidade.

As hipóteses que justificavam tal fonte independente de desprazer na sexualidade foram sendo tecidas ao longo de vários textos. Uma das primeiras hipóteses lançadas por Freud encontra-se em outra carta enviada a Fliess em 1987, onde sugere uma origem filogenética relacionada ao momento da mudança postural dos primatas para a posição vertical. Este novo "panorama" atingiu certas zonas sexuais: "Muitas vezes suspeitei de que alguma coisa orgânica desempenhava um papel no recalcamento; (...). Confidencialmente, a ninguém concedo prioridade na idéia; no meu caso, eu ligava essa idéia de recalque à modificação do papel desempenhado pelas sensações do olfato: a adoção da postura ereta, o nariz levantado do chão, ao mesmo tempo que uma série de sensações, que antes despertavam interesse e eram relacionadas à terra, tornaram-se repulsivas - por um processo que ainda me é desconhecido."149 Além desta hipótese, Freud rumou para a questão da bissexualidade, intensamente defendida por Fliess, como

\footnotetext{
${ }^{146}$ Freud, Sigmund. (1907) O Esclarecimento Sexual das Crianças. Obras Psicológicas Completas de Sigmund Freud, vol. IX, Rio de Janeiro, Imago, 1988, pp. 127-128.

${ }^{147}$ Um exemplo dessa discussão em: Freud, Sigmund. "Conferência XXIII - Os Caminhos da Formação dos Sintomas". In (1917) Conferências Introdutórias Sobre Psicanálise. Obras Psicológicas Completas de Sigmund Freud, vol. XVI, Rio de Janeiro, Imago, 1976, pp. 426-427.

148 "Manuscrito K, $1^{\circ}$ de janeiro de 1896". In Masson, J.F. (org.) Correspondência Completa de Sigmund Freud Para Willelm Fliess - 1887-1904. Op. cit., p. 164.

${ }^{149}$ Carta de 14 de novembro de 1897. Idem, p. 280.
} 
mais uma explicação sobre a origem do recalcamento. Segundo esta idéia, a satisfação sexual plena seria irrealizável diante da impossibilidade de satisfazer, com um objeto, ambos os componentes da sexualidade.

Catherine Millot indica-nos que foi a descoberta da sexualidade infantil que proporcionou o esclarecimento da natureza da sexualidade humana e a reativação da questão das relações entre sexualidade e civilização. Conseqüentemente, "lançou uma nova luz sobre a natureza do processo educacional e impulsionou Freud a se ocupar desse problema." 150

Como acabamos de ver, Freud, de início, acreditou que o recalque era produzido pelo conflito psíquico entre as tendências sexuais e a consciência moral do indivíduo. Por isso acalentou a ilusão de que as neuroses poderiam ser evitadas por uma educação que não reproduzisse a moral sexual, que não reprimisse, além dos atos, o pensamento. Depois, percebeu que a origem do recalque está no desprazer inerente à sexualidade, e que a moral é uma defesa contra este desprazer. Posteriormente, Freud descreve o caráter conflitivo da sexualidade como decorrente da oposição entre duas pulsões: as pulsões sexuais que colocam o organismo em perigo, pois, comandadas pelo princípio do prazer, buscam cegamente a satisfação; e as pulsões do Eu que, guiadas pelo princípio da realidade, limitam a atividade puramente pulsional, procurando a obtenção de prazer sem que o indivíduo se destrua. Em suma, a dinâmica entre as duas pulsões no indivíduo seria um regulador na busca do prazer ou, no máximo, uma exposição a menor desprazer: uma concepção hedonista do aparelho psíquico.

Até aqui, Freud aponta um freqüente combate entre as forças instintivas e a civilização, que levaria à interpretação de que os limites impostos pela sociedade à irracionalidade da sexualidade humana seriam, então, responsáveis pela não satisfação dos impulsos e, portanto, pelo desprazer. Por outro lado, foi necessário reconhecer que a civilização só pôde se formar a partir do aproveitamento das pulsões originalmente perversas para fins sociais. Aliás, desta vez diferente de Rousseau, Freud não acreditava na criança essencialmente boa, embora não tenha dito que fosse má, mas acreditava que à educação cabia a tarefa de encaminhar a perversão para a sublimação, isto é, encaminhá-la a saídas socialmente aceitáveis, já que a sexualidade não está predeterminada a nenhum fim específico. Emprestando a fala do Prof. Osmyr Faria Gabby Jr., em aula proferida no curso de especialização em Psicanálise, na UNICAMP,

${ }^{150}$ Millot, Catherine. Freud Antipedagogo. Rio de Janeiro, Jorge Zahar Editor, 1995, p. 21. 
em 1997, “a educação perverte a tendência perversa do homem.” Em 1913, no conjunto de textos intitulado $O$ Interesse Científico da Psicanálise, Freud especifica o papel da educação perante as forças instintivas: "Nossas mais elevadas virtudes desenvolveramse, como formações reativas e sublimações, de nossas piores disposições. A educação deve escrupulosamente abster-se de soterrar essas preciosas fontes de ação e restringirse a incentivar os processos pelos quais essas energias são conduzidas ao longo de trilhas seguras." 151

Neste ponto, a teoria freudiana mostra-se realmente pessimista. Se não há satisfação direta e imediata do que reclama a sexualidade humana, pois não há como conciliá-la às restrições da civilização, a felicidade não é alcançada na sua plenitude. A renúncia e o sofrimento do homem são condições para o desenvolvimento da civilização.

Apesar dos avanços de Freud na teoria da sexualidade humana, ainda restava um importante problema: se o lema da dinâmica do psiquismo é a busca do prazer, ou do menor desprazer possível, como se explicaria a repetição de situações aflitivas, presente no pensamento e no comportamento dos neuróticos? Freud teve de reconhecer a existência de uma terceira força, independente dos princípios do prazer e da realidade. Cristina Kupfer descreve esta força independente e contrária: "Essa força tem um caráter sobretudo mortal. Pois, contrariamente à ação do conflito, que movimenta o indivíduo, a ação da repetição fixa, homogeneíza, torna as coisas permanentes e imutáveis e barra o caminho ao desenvolvimento. Ou seja, encena, de certo modo, a morte, lugar por excelência da ausência de movimento, lembrando com isso seu parentesco com ela." $" 152$

A noção de pulsão de morte veio tornar mais inteligível algumas "estranhezas" no comportamento humano, que estão dissociadas da idéia de satisfação. E a partir desta descoberta, o conflito no interior do psiquismo não pôde mais ser entendido como oposição entre o princípio de prazer (pulsão sexual) e princípio de realidade (pulsão do $\mathrm{Eu}$ ), tendo em vista que ambas as pulsões remetem à vida: a primeira visa à conservação da espécie, e a segunda, à sobrevivência. Agora, a oposição é entendida entre pulsão de vida e pulsão de morte.

\footnotetext{
${ }^{151}$ Freud, Sigmund. (1913) O Interesse Científico da Psicanálise. Obras Psicológicas Completas de Sigmund Freud, vol. XIII, Rio de Janeiro, Imago, 1995, p. 191.

${ }_{152}$ Kupfer, Maria Cristina M. Freud e a Educação: O Mestre do Impossível. São Paulo, Ed. Scipione, 1997, p. 56.
} 
Esta nossa rápida incursão pelo pensamento freudiano sobre o funcionamento do psiquismo humano serve-nos para compreender o que significa sua afirmativa sobre a impossibilidade da educação. Não existe uma educação livre de repressão, já que esta é constitutiva, isto é, as restrições morais não surtiriam efeito se não houvesse uma disposição do psiquismo a impedir toda a satisfação. As esperanças de uma civilização feliz e mais sadia, através de uma educação menos repressora, revelaram-se uma grande ilusão. Em suma, diante da realidade do inconsciente e da pulsão de morte, os ideais de promoção de bem-estar e de felicidade presentes na educação mostram-se irrealizáveis.

Vale ressaltar que, quando se fala da impossibilidade da educação, não se está dizendo que as crianças não sejam afetadas pela educação, ou melhor, a impossibilidade não está na aprendizagem. O que se revela impossível na educação é qualquer tentativa de controle do processo educativo, tal como pretende a Pedagogia com seus parâmetros (os PCNs), por mais ligados que estejam à idéia de promoção do bem-estar. Aquilo que se apreende e se elabora no ato educativo está para além da previsão e domínio dos pedagogos, para além do pretenso ajuste psicológico da relação, pois se encontra submetido às leis que regem o psiquismo humano, dentre elas a transferência.

Devemos concluir também que, mesmo tendo descoberto certas leis do aparelho psíquico, a Psicanálise não pode servir como fundamento para a Pedagogia, muito menos propor métodos de ensino, pois estaria contradizendo as suas próprias formulações.

\section{Sobre A Possibilidade de Uma Educação}

Quando Freud dizia que os resultados obtidos pelos governantes, analistas e educadores são sempre insatisfatórios, referia-se à falta de garantias sobre seus resultados, à impossibilidade de se manipularem os efeitos. E, mais ainda, estas profissões se tornam impossíveis quando existe a pretensão de se formatar a diferença evidente entre os sujeitos, uma hegemonia fundada no desejo desses profissionais de encarnarem o ideal. 
Todavia, a impossibilidade diante da qual os três ofícios deparam não determina que não se realize um governo, uma análise e uma educação. ${ }^{153}$ Assim, a afirmação freudiana não prevê o imobilismo ou a omissão destes profissionais. Aliás, são eles mesmos que, à medida que se referem a um ideal, sustentam o desdobramento da diferença.

Procuremos, agora, identificar nas palavras de Freud a possibilidade de uma educação.

\section{$* * *$}

Mesmo que, de início, se identifique em Freud certa esperança de encontrar na educação um meio para proteger a humanidade da neurose e, dessa forma, produzir indivíduos mais felizes (o que se revela uma ilusão), devemos considerar que Freud pensava a educação a partir de uma realidade educativa que, segundo ele, prejudicava a curiosidade intelectual, malogrando sua função. Os ideais da educação nos tempos de Freud estavam atrelados ao ideal religioso. Era em nome desse ideal, encarnado pelos educadores, que a educação tencionava tornar todos iguais.

Assim, compreendemos as críticas de Freud, como uma maneira de exprimir uma outra possibilidade de educação em que o adulto pudesse se endereçar às crianças em nome de outra coisa que não fosse a moral de seu tempo. ${ }^{154}$ Propõe, então, uma educação: "a educação para a realidade", definida por Lajonquière desta forma: "Assim, educar para a realidade é sinônimo de educar para o desejo ou, se preferimos, permitir o reconhecimento da impossível realização do desejo - quer dizer, a característica artificial de seu estofo - justamente mascarada pelas ilusões religiosas."155

Como pensar uma educação que reconhece o desejo, ao mesmo tempo que aponta para sua impossibilidade de realização?

Alguns leitores poderiam pensar que "reconhecer o desejo do aluno" significaria deixá-lo livre para fazer o que quiser (ou supõe querer) e, dessa forma, torná-lo mais feliz. O que Freud diz diverge dessa idéia: “A criança deve aprender a controlar seus

\footnotetext{
${ }^{153}$ Lajonquière, Leandro de. Infância e Ilusão (Psico)Pedagógica: Escritos de Psicanálise e Educação. Petrópolis, Vozes, 1999, p. 165.

${ }^{154}$ Uma exposição mais ampla sobre esse tema encontra-se em: Lajonquière, Leandro de. Freud, l'Éducation et les Enfants: Entre la Psychanalyse et le Politique. In Les États Généraux de la Psychanalyse, Paris, La Sorbonne, 2000, <http://members.aol.com/call971/texte73.html>.

${ }^{155}$ Idem, p. 6.
} 
instintos. É impossível conceder-lhe a liberdade de pôr em prática todos os seus impulsos sem restrição. Fazê-lo seria um experimento muito instrutivo para os psicólogos de crianças; mas a vida seria impossível para os pais, e as próprias crianças sofreriam grave prejuízo, que se exteriorizaria, em parte, imediatamente, e, em parte, nos anos subseqüentes." 156 Portanto, a educação não pode se furtar do mal-estar de impor ao aluno uma proibição, mas ela pode mostrar que a vida é possível ao sujeito a partir de dois "sintomas": amar e trabalhar.

Bem, Freud lembra que reprimir é o que a educação vinha fazendo há muito tempo e, como presenciava em sua época, reprimia-se em nome de um ideal religioso. Esse modelo de educação apoiada numa repressão intensa trazia prejuízos à curiosidade intelectual dos alunos. Então, apesar do papel repressor da educação, esta deve ter em vista a necessidade de não tirar da cena o dispositivo da aprendizagem: o desejo de saber.

Freud confere à educação uma difícil missão: “Assim, a educação tem de escolher seu caminho entre o Sila da não-interferência e o Caríbdis da frustração. A menos que o problema seja inteiramente insolúvel, deve-se descobrir um ponto ótimo que possibilite à educação atingir o máximo com o mínimo de dano. Será, portanto, uma questão de decidir quanto proibir, em que hora e por que meios." ${ }^{157}$ Tal decisão, imaginariam os educadores, pode ser conferida aos métodos de ensino que supostamente trazem, como fundamento, uma construção teórica consistente. No entanto, Freud deixa tal decisão sob responsabilidade exclusiva de cada educador: "E, ademais, devemos levar em conta o fato de que os objetos de nossa influência educacional têm disposições constitucionais inatas muito diferentes, de modo que é quase impossível que o mesmo método educativo possa ser uniformemente bom para todas as crianças." ${ }^{158}$ Em outras palavras, tendo em vista a singularidade dos sujeitos, a "medida certa", se assim se pode falar, de permissão e frustração é diferente para cada um.

O permitir e o não permitir da educação poderia ser assim exposto: não permitir que os impulsos se manifestem tais como são na origem, ao mesmo tempo permitir que

\footnotetext{
${ }^{156}$ Freud, Sigmund. "Conferência XXXIV - Explicações, Aplicações e Orientações" (1933). In Novas Conferências Introdutórias Sobre Psicanálise. Obras Psicológicas Completas de Sigmund Freud, Rio de Janeiro, Imago, 1994, p. 147.

${ }^{157}$ Freud, Sigmund. "Conferência XXXIV - Explicações, Aplicações e Orientações" (1933). In Novas Conferências Introdutórias Sobre Psicanálise. Obras Psicológicas Completas de Sigmund Freud, Rio de Janeiro, Imago, 1994, p. 147.

${ }^{158}$ Idem, p. 147.
} 
eles sejam encaminhados às atividades culturais. Educar para a realidade consiste em uma educação mais ampla do que aquela apoiada nos princípios religiosos, consiste numa educação conduzida pelo princípio da realidade. Realidade formada pela construção cultural da humanidade e organizada a partir de um conjunto de leis.

Buscando retomar as discussões realizadas nos capítulos anteriores, diremos que o professor somente poderá fazer a educação transitar entre o proibir e o permitir quando não estiver destituído da posição de autoridade, enquanto estiver sustentando a diferença entre ele e o aluno.

Além disso, acreditar num ideal psicológico (tal como um ideal religioso) ao qual o aluno deve conformar-se significa uma tentativa de acabar com a diferença, negando a singularidade do sujeito do desejo e, mais do que isso, configura-se no aproveitamento da transferência (da dependência do aluno) no sentido de pervertê-la.

Matar a diferença pela não sustentação da autoridade, pelo imperialismo de um ideal psicológico é tornar toda e qualquer educação impossível.

\section{A Transferência e o Desejo de Saber}

A questão da aprendizagem no interior da Psicanálise implica na investigação sobre o desejo de saber. Constatamos formulações iniciais sumamente importantes em Freud que, posteriormente, se ampliam nas proposições lacanianas.

A origem do desejo de saber é explicada a partir da teoria freudiana sobre a sexualidade infantil. Em 1905, Freud escreve Três Ensaios Sobre a Teoria da Sexualidade onde mostra os caminhos percorridos pela pulsão sexual. Umas das principais idéias presentes nesse trabalho indica que não existe um objeto único e predeterminado na direção das pulsões sexuais, isto é, a energia originariamente sexual pode se ligar a objetos de diferentes naturezas.

Freud considera orgânica a origem da pulsão sexual e seu desenvolvimento. Porém, alguns impedimentos se impõem, estreitando o caminho daquilo que foi 
organicamente fixado: o asco, o sentimento de vergonha, as exigências dos ideais estéticos e morais. "Nas crianças civilizadas, tem-se a impressão de que a construção desses diques é obra da educação, e certamente a educação tem muito a ver com isso." 159 A sublimação é o processo em que a energia das moções sexuais infantis é desviada do uso sexual e voltada para outros fins. Esse processo é responsável pelas realizações culturais, portanto, pela adaptação social do indivíduo.

Apesar da dominação preponderante das zonas erógenas, a vida sexual infantil exibe componentes que, desde o início, envolvem outras pessoas como objetos sexuais. Desta maneira, Freud explica a existência das pulsões parciais: as pulsões do prazer de olhar e de exibir (pulsão escópica), a sucção (pulsão oral), a defecação (pulsão anal), bem como a de crueldade que, independentes das zonas erógenas, somente mais tarde se relaciona com a vida genital. Podemos perceber tais pulsões de prazer na vida sexual adulta.

Mesmo envolvendo outras pessoas como objetos sexuais (para serem vistos, para verem, para serem controlados ou agredidos), o prazer que a criança busca tem a pulsão dirigida para o próprio corpo: o auto-erotismo. O corpo do outro só será alvo de interesse sexual quando se realizar o desenvolvimento da genitalidade, última etapa do desenvolvimento psicossexual.

É justamente essa característica polimorfa do objeto da pulsão sexual, tal como vemos nos casos das perversões, que faz da educação a via pela qual as tendências perversas são convertidas, através da sublimação, para fins socialmente úteis (as produções culturais). É justo concluir, então, que a educação perverte a natureza perversa do homem, pois pode dirigir a pulsão sexual para fins não sexuais.

Entretanto, não se trata de eliminar a fonte das pulsões sexuais no sentido de combater um mal em nome de um bem, mas de reconhecer esta fonte e utilizá-la, enquanto a transforma em bens culturais. Sem perversão não há sublimação, sem sublimação não há cultura.

Vejamos, então, como a educação pode utilizar as pulsões sexuais em benefício do desenvolvimento cultural e social dos indivíduos.

A pulsão de saber ou de investigar, segundo Freud, floresce entre os três e os cinco anos de idade e corresponde, uma parte, à sublimação e outra, à pulsão escopofílica (uma das pulsões parciais). "Suas relações com a vida sexual, entretanto,

\footnotetext{
${ }^{159}$ Freud, Sigmund. (1905b) Três Ensaios Sobre a Teoria da Sexualidade. Obras Psicológicas Completas de Sigmund Freud, vol. VII, Rio de Janeiro, Imago, 1988, p. 167.
} 
são particularmente significativas, já que constatamos, pela Psicanálise, que, na criança, a pulsão de saber é atraída, de maneira insuspeitamente precoce e inesperadamente intensa, pelos problemas sexuais, e talvez seja até despertada por eles."160

Freud aponta situações que levariam a criança a atitudes de reflexão e investigação. A primeira delas seria a ameaça pela chegada conhecida ou suspeita de um novo bebê e, consequientemente, a perda de cuidados e de amor. O primeiro problema que desperta o desejo de saber é, então, o enigma sobre a origem dos bebês. A partir desta investigação surge um grande conjunto de teorias sobre o nascimento de bebês: sairiam do seio, do umbigo ou, depois de ingerida uma determinada coisa, os bebês nasceriam pelo ânus, como na eliminação das fezes.

Mais tarde, é a diferença sexual que incita o desejo de saber. "Mas como dois elementos permanecem desconhecidos na investigação sexual infantil, a saber, o papel do sêmen fecundante e a existência do orifício sexual feminino - os mesmos pontos, aliás, em que a organização sexual infantil ainda está atrasada -, os esforços do pequeno investigador são geralmente infrutíferos, e acabam numa renúncia que, não raro, deixa como seqüela um prejuízo permanente para a pulsão de saber." 161

Sobre a questão do prejuízo na pulsão de saber, Freud considera que as crianças fazem suas investigações na solidão e, não conseguindo avançar nelas por um emprego maciço da repressão pelo adulto, o resultado seria de danos na atitude investigativa, com consequiências futuras. Portanto, Freud já alude à responsabilidade do adulto na preservação e emprego da pulsão de saber.

Antes disso, Freud revela que existe um momento em que a diferença anatômica, que anteriormente não chamava a atenção das crianças, pois até então poderiam acreditar que todos seriam dotados de pênis, a partir de agora passa a ser foco de investigação infantil, porque as crianças se dão conta de que o mundo se divide em seres com pênis e seres sem pênis. "Se encontramos seres sem pênis", pensa uma criança, "é porque esta pessoa pode tê-lo perdido". A diferença anatômica entre homens e mulheres remete à idéia da falta e reedita antigas perdas, como a do seio e a das fezes. Assim, vem despertar uma angústia que Freud chama de angústia de castração.

Até aqui é possível compreender que o desejo de saber é derivado da repressão das pulsões, da insatisfação; portanto, tem sua origem na sexualidade dos indivíduos. Entretanto, os fatos que Freud aponta como disparadores do desejo de saber e sua

\footnotetext{
${ }^{160}$ Freud, Sigmund. (1905b) Três Ensaios Sobre a Teoria da Sexualidade. Op. cit., p. 183.

${ }^{161}$ Idem, pp. 187-188.
} 
relação com a angústia de castração ainda não são suficientes para entender a ameaça de perda presente em todas as crianças. Poderíamos lembrar que Freud fala da chegada conhecida ou suspeita de um novo bebê. Essa chegada pode não se realizar, mas persiste a ameaça de perda.

Então, como nos explica Cristina Kupfer, "Freud mesmo percebeu isso e buscou determinantes mais estruturais para isso que, a princípio, ele apenas observou. Essa busca dos determinantes estruturais levou-o justamente a desenvolver melhor um dos aspectos mais importantes de sua teoria: o complexo de Édipo."162 Uma alusão ao mito de Sófocles, em que o personagem Édipo, sem saber, casa-se com sua mãe Jocasta, depois de matar seu pai Laio. O complexo de Édipo relaciona-se com a universalidade da proibição do incesto. É a denominação que Freud utilizou para representar um processo em que a criança é desviada de seu desejo incestuoso. Ao reconhecer o obstáculo que se impõe, representado pela função paterna, estabelece-se o complexo de castração, que significa um registro da perda nos investimentos incestuosos e, por conseguinte, uma constante ameaça de perda.

Ao atravessar o complexo de Édipo, o menino se apropria da identidade masculina e a menina, da identidade feminina. Este processo traduz uma questão que acompanha todas as investigações infantis: qual é o lugar que ocupa no mundo? Saber sobre este lugar, que a princípio é um lugar sexual, remete à questão sobre a origem das coisas, portanto, da própria origem. A pergunta pela origem acompanha o sujeito, porque o move, nas investigações sucessivas.

Em suma, as proposições de Freud sobre o desejo de saber vêm mostrar a origem sexual das investigações, a pluralidade de objetos com os quais as pulsões sexuais encontram a satisfação, a sublimação como o mecanismo que permite a satisfação de pulsões sexuais por produções culturais e, finalmente, o papel da educação na utilização da pulsão sexual em benefício da sociedade, isto é, a promoção da sublimação.

Já vimos em Freud a universalidade do complexo de Édipo e seus efeitos subseqüentes, principalmente a instalação da angústia de castração. A falta e a ameaça

\footnotetext{
${ }^{162}$ Kupfer, Maria Cristina M. Op. cit., p. 80.
} 
da perda seriam os produtos deste processo e estariam como pano de fundo nas relações estabelecidas pelo indivíduo com o mundo.

Para ampliarmos a discussão sobre o desejo de saber, podemos retornar um pouco às proposições de Lacan, sobre as quais tratamos no segundo capítulo deste trabalho.

Lembremos que, segundo Lacan, quando uma criança vem ao mundo, imediatamente se encontra inscrita numa rede de relações simbólicas que envolve os desejos maternos. Sustentado pela mãe, o bebê vê uma imagem no espelho, imagem identificada pela mãe como sendo o próprio bebê: num primeiro momento o bebê reconhece que há um outro no espelho; num segundo momento, reconhece que há uma imagem refletida no espelho; e, finalmente, o sujeito se reconhece na imagem ali projetada. Nesta passagem pelo estádio do espelho, o bebê reconhece um Real que é seu corpo para construir um Eu Imaginário, mas alinhado no Simbólico. Verificamos aí o papel mediador da mãe entre o bebê e um terceiro, a cadeia simbólica da linguagem. E, apesar da ambivalência da relação imaginária com o filho (ódio e amor) e dos desejos que imprime nele, a mãe ajuda seu filho a integrar uma rede simbólica e a existir.

Devido principalmente à dependência gerada pela necessidade de sobrevivência, a criança procura compor com a mãe uma célula narcísica que caracteriza uma ilusão de completude. Para garantir isto, procura conformar-se aos desejos maternos. Porém, os desejos de uma mãe não terminam (pelo menos não devem terminar) no bebê, o que a leva a redirecionar seu olhar, desviando-o da criança, tendo como principal alvo o seu companheiro (na maioria das vezes, o pai da criança). O mais importante é compreender que algo se interpõe ao desejo de completude na relação mãe-bebê: uma lei simbólica, a proibição do incesto. A impossibilidade de satisfazer os desejos maternos faz com que o bebê se perceba como um ser em falta, assim como se mostra sua mãe ao procurar realizar-se também com um outro.

É graças à castração operada no interior da relação mãe-bebê que se inscreve o registro da falta e, portanto, a instalação do desejo. $O$ sujeito passa a desejar ser reconhecido e, na busca do reconhecimento, almeja saber sobre o desejo do outro. Então, o desejo de saber para Lacan, como para Freud, instala-se a partir do momento em que se opera a angústia de castração. A partir daí, o sujeito acredita que no outro está a verdade sobre seu desejo. Em outras palavras, desejar saber sobre o desejo do outro é supor neste outro o saber sobre o próprio desejo, isto que lhe falta, o objeto $a$, fazendo com que o sujeito aposte na transferência. 
Assim como o paciente em análise supõe no analista o saber sobre aquilo que the falta e o angustia, o professor na realidade educacional é, por excelência, um outro em quem o aluno supõe o saber sobre o lugar que ele ocupa no mundo, o saber sobre a vida, o saber sobre como se tornar adulto, o saber sobre os desejos dos pais que o colocaram na escola. Para o aluno, o professor é aquele que sabe sobre o seu desejo: ele é o sujeito suposto saber.

Esta posição em que paciente e aluno colocam, respectivamente, analista e professor, é o primeiro movimento da realidade transferencial e caracteriza-se por uma condição de dependência. Transferem a estes outros dotados de saber (a estas autoridades) o saber sobre seus desejos. Em uma palavra, sob o registro da castração, o sujeito procura no outro o saber sobre aquilo que lhe falta. A transferência, como vimos, tem como princípio constitutivo o Sujeito Suposto Saber porque, do outro lado, há um sujeito que demanda (demanda de amor, de reconhecimento).

No entanto, para que o aluno realmente possa supor o saber no professor, este deve assumir o lugar de quem sabe sobre esta diferença que se aninha entre eles. Deve sustentar a posição de representante do saber em que é colocado. Deve fazer semblante de quem possui $o$ saber.

Porém, sabemos que o aluno está motivado, no encontro com o professor, pela angústia de castração que o faz reeditar nesta situação a posição edípica, idealizando o professor como detentor do falo (aquilo que lhe falta), como sujeito suposto tudo saber e tudo poder. O professor, por sua vez, atualiza na relação com o aluno suas questões narcísicas, tomando o aluno também como representante do falo. O resultado dessas duas demandas que idealizam o encobrimento da falta é o que podemos chamar de uma paixão transferencial que vem, como efeito, impedir a paixão pelo conhecimento.

Para que ambos não sejam presas da ilusão de recuperar uma completude já vivida, o registro da castração deve permanecer. O professor deve reconhecer que, apesar de representar o saber sobre a diferença, não sabe sobre o universo interior do aluno. Deve lembrar que a ele também falta (assim como à mãe do bebê) e que deve sempre buscar em outras fontes o que lhe falta saber. Podemos verificar que a experiência do complexo de Édipo se repete porque começa numa ilusão de completude e termina em dois sujeitos que permanecem desejando.

Retomando o papel da mãe como mediadora entre o bebê e a rede simbólica, como diz Philippe Willemart: "Por analogia, a formação consistiria em inserir a criança, 
o adolescente ou o universitário em outras redes simbólicas."163 Willemart marca claramente o papel do professor: "Sem o professor que chama e exige, a inteligência do aluno ficará parada à mercê de outras chamadas e não haverá formação. (...) diria entretanto que não é o aluno que vai interpretar os signos em primeiro lugar, mas o professor que, além de interessar os alunos em sua matéria, vai interpretar os signos."164

Os signos interpretados pelo professor, sejam eles os da matemática, da língua, da realidade econômica, da política, familiar, entre outros, para os alunos são ainda parte do Real, do registro do não conhecido, do irredutível, isto é, não sabem como ler esses signos. "Trata-se portanto de ajudar o aluno a emergir nestas novas redes, a nascer nelas como sujeito e não mais ser levado por elas sem saber."165

Concluímos daí que o perigo se encontra em o professor acreditar que realmente possua o saber sobre o desejo, sobre o bem-estar no mundo, saber e ser o que falta ao aluno, podendo assim aprisionar e alienar o aluno em seu discurso, à medida que perverte a transferência. Outro perigo, comum na Pedagogia atual, é o de o professor renunciar à posição em que é colocado pelo aluno, ocupando uma posição passiva de espera por um pretenso desenvolvimento natural, ou se destituindo do saber, por atribuílo aos especialistas do desenvolvimento (os supostos representantes da ciência). Em suma, o educador deve oferecer-se como detentor deste saber que lhe é suposto na transferência. Por isso, dizemos que o professor faz semblante de que sabe. Mas este jogo de "me engana que eu gosto" está, como sabemos, submetido ao registro da castração que permite escapar, desta "mentira", uma verdade, a saber, de que o próprio professor está sujeito a uma permanente busca da verdade de seu desejo e, portanto, desvia seu olhar do aluno para possíveis fontes deste saber: os livros, seus próprios mestres, enfim, outros.

Tendo em vista que não há manejo da transferência, que não há simetria na relação, não é possível elaborar uma fórmula psicanalítica que resulte numa condução adequada da educação. No entanto, a teoria psicanalítica sobre o desejo de saber indica duas condições para que a educação cumpra seu papel e estas condições dizem respeito

${ }^{163}$ Willemart, Philippe. "Psicanálise e Pedagogia ou Transmissão e Formação". In Revista USP. São Paulo, setembro/novembro 1996, p. 203.

164 Idem, p. 204.

${ }^{165}$ Willemart, Philippe. Psicanálise e Pedagogia ou Transmissão e Formação. Op. cit., p. 204. 
à noção de transferência: primeiro, que o professor sustente a posição de sujeito suposto saber que lhe é atribuída pelo aluno e interprete para ele os signos; segundo, que o registro da castração se encontre presente, no sentido de manter professor e aluno em busca do saber sobre seus desejos. Em outras palavras, o professor precisa alimentar a suposição de saber transferido pelo aluno, mantendo-se, ele próprio, ligado às construções culturais e acreditando na sua transmissão, sendo o mediador entre o aluno e o conhecimento, enquanto deve reconhecer, para si mesmo, que não sabe tudo.

Em suma, é a falta que leva o aluno a transferir e, assim, atualizar a realidade de seu inconsciente na figura do professor. E sobre isto que lhe é transferido, o professor não tem nenhum domínio, não dá para estabelecer a idealizada "relação". Então, se ao educador não for possível reconhecer aquilo que marca o ser humano, a saber, a angústia, a falta, estará fadado a acreditar nos pretendidos controles, em métodos eficientes que garantam uma educação adequada a todos, numa relação psicologicamente ajustada. Poder-se-ia dizer que a negação da falta constitutiva, a negação da transferência, então, é responsável por uma constante insatisfação pedagógica.

\section{A Transferência e a Impossibilidade da Educação}

Há pouco, e mais ainda no primeiro capítulo, discutimos sobre a diferença inerente ao encontro entre um adulto e uma criança e o papel do adulto na educação desta criança. Pois bem, cabe compreender melhor as vicissitudes deste encontro.

Segundo Freud, ao educador cabe a tarefa de encaminhar as pulsões originariamente perversas da criança a vias socialmente úteis. A criança necessita da existência de um adulto para se tornar um humano "civilizado", para ser habitado pelo desejo. Contudo, o ato de educar uma criança não ocorre sem conflitos, dúvidas e arrependimentos. Isto é, o caminho pelo qual o adulto conduz a criança no processo educativo não é linear nem imune a erros. 
Qual a razão deste traço irregular do encontro educativo? Seria um reducionismo considerar este encontro como sendo entre dois indivíduos apenas. Aliás, é esta ilusão que alimenta o esforço da Pedagogia atual em controlar os estímulos proporcionados pelo professor à natureza cognitiva e emocional do aluno - controlar aquilo a que chama de relação professor-aluno. Neste encontro, diversos outros estão implicados. Tentaremos colocar à luz o que educador e aluno, cada um deles, trazem consigo ao se encontrarem.

Recorrendo mais uma vez a Freud: "Somente alguém que possa sondar as mentes das crianças será capaz de educá-las e nós, pessoas adultas, não podemos entender as crianças porque não mais entendemos a nossa própria infância. Nossa amnésia infantil prova que nos tornamos estranhos à nossa infância."166 Bem, este trecho deixa transparecer uma esperança de que, dominando a teoria psicanalítica sobre os processos do desenvolvimento infantil, portanto, refrescando suas lembranças sobre as crianças que foram, os adultos seriam capazes de melhor educar. Ocupar-nos-emos depois de mostrar que se trata, em parte, de um engano. Mesmo assim, sobre isso Freud nos diz coisas importantes.

Sabemos que Freud não foi muito pródigo no tema da educação. Por outro lado, também sabemos da universalidade da teoria psicanalítica. A Psicanálise trata do psiquismo humano, independente do lugar ou da situação em que este humano se encontra. Os estudos atuais em Psicanálise e Educação procuram utilizar o raciocínio psicanalítico para compreenderem o ato educativo.

Portanto, se Freud nada prescreve para que os adultos se "curem" da amnésia denunciada no trecho anterior (exceto quando prescreve uma análise pessoal), ele, com propriedade, expõe a etiologia do esquecimento.

Retomemos, então, o que foi mais amplamente tratado no segundo capítulo deste trabalho.

Devemos lembrar que apenas parte dos impulsos completou o desenvolvimento psíquico (e está voltada para a realidade), enquanto uma outra parte, composta por conteúdos aflitivos, foi impedida de expandir-se e, retirada do curso de desenvolvimento, recalcada, permanece inconsciente (que Freud compara à parte submersa do iceberg). As atitudes dos indivíduos, suas maneiras peculiares de agir, os

${ }^{166}$ Freud, Sigmund. (1913) O Interesse Científico da Psicanálise. Op. cit., p. 190. 
clichês estereotípicos são o resultado da série de representações existentes nas duas instâncias.

Portanto, o conteúdo aflitivo, que permanece inconsciente, também se manifesta. O esquecimento é considerado uma interceptação deste conteúdo que já fora recalcado. A incapacidade de recordar vem, então, acionar a disposição à repetição. Esquecimento e repetição estão intimamente ligados e são manifestações do inconsciente, como já vimos no segundo capítulo.

Levando em conta as séries de representações presentes nas duas instâncias, representações existentes desde que o psiquismo foi inaugurado, compreendemos que nas relações sucessivas as pessoas reproduzem as primeiras experiências. Estamos falando novamente sobre a transferência.

Voltando à questão do esquecimento do adulto sobre sua infância, podemos considerar que este esquecimento significa também um retorno de seus conteúdos infantis. Diante de uma criança, o adulto é remetido a um outro, a criança dentro de si, seus desejos infantis outrora recalcados.

Cifali $^{167}$ aborda a realização da criança existente no adulto através da criança com a qual este adulto se encontra. Ao deparar com uma criança, o adulto se questiona sobre a maneira de ajudá-la a se desenvolver, sem que tenha de passar por dificuldades. E, para poupar a criança do sofrimento causado pela educação, o adulto lança mão de várias justificativas.

Essa autora ainda diz que pensar no sofrimento causado pela educação remete à questão da responsabilidade pelos "danos" causados pela mesma. Daí surgem duas versões dentro da Psicanálise: a primeira, de que a criança é vítima da violência do adulto (concepção característica da primeira teoria freudiana, depois abandonada, sobre a origem da neurose - a teoria da sedução), versão esta que incrimina o adulto; a segunda, de que a criança é essencialmente perversa, e que suas fantasias são suficientes para a formação de sua neurose. Por isso, deve ser bem encaminhada pelo adulto (o mal estaria na criança).

Apesar de Freud ter abandonado a teoria da sedução, Cifali considera válidas ambas as versões. Isto é, a responsabilidade não é totalmente do adulto, tampouco exclusiva da criança. Sem dúvida, os adultos, à medida que educam, desenvolvem importante papel na formação das neuroses. Apesar das boas ou más intenções do

167 Cifali, Mereille. Le Lien Éducatif: Contre-Jour Psycanalytique. Paris, Presses Universitaires de France, 1994. 
adulto, coisas importantes do seu próprio psiquismo lhe escapam. A autora resume isto brilhantemente: “A educação segue entre proximidade e distância, entre paixão, amor e violência."168

A violência na educação ocorre em decorrência de um temor do adulto em relação àquilo que a criança lhe desperta. Isto, segundo Cifali, explicaria a pedagogia da humilhação e da exploração da dependência da criança em relação ao adulto.

Maud Mannoni abordou a violência na educação expondo uma análise do caso Schreber (caso anteriormente analisado por Freud). ${ }^{169}$ Schreber recebeu de seu pai uma educação pervertida que resultou, mais tarde, na eclosão de uma psicose. "O Dr. D. G. M. Schreber encarnava um saber científico (um educador, dizia ele, é um homem que tem resposta para tudo), dotado do poder de cura. Para que esse poder possa exercer-se, é preciso ainda um paciente capaz de submissão total, de abandono radical do seu corpo e do seu ser. (...) Renunciar à obediência seria, portanto, renunciar à vida." ${ }^{170}$ Esta parece ser característica de uma educação mais "retrógrada", isto é, supostamente menos comum hoje.

Por outro lado, existe uma nova regra em vigor no campo da Educação, menos controvertida, pois parece resultar de educadores menos angustiados. Esta regra, opondo-se ao autoritarismo da educação de tempos passados, revelada pela ciência moderna, volta-se para o extremo oposto: deixa a criança à sua própria sorte, isenta-se da responsabilidade pela educação.

Apesar da acentuada diferença entre a prática da educação autoritária e a educação laisser-faire, ambas são motivadas por supostos saberes científicos. Ou melhor, os princípios que regem a Educação assemelham-se ao longo da história: estão sempre submetidos a um inevitável imaginário educativo que desenvolve um discurso voltado para um ideal: o bem da criança. Saber sobre o bem-estar no mundo configurase, muitas vezes, num autoritarismo tal qual o do Dr. Schreber, pois se tenta conformar a criança a um ideal preestabelecido e que carrega os desejos de quem procura realizálo. Configura-se, portanto, na perversão da transferência.

Para que qualquer "bem” idealizado seja alcançado via educação, o adulto não pode fugir da autoria do que Cifali chama de "morte psíquica" ou "assassinato de alma", isto é, ele não pode se furtar de infligir certo sofrimento à criança. E tal missão não é

\footnotetext{
${ }^{168}$ Cifali, Mereille. Le Lien Éducatif: Contre-Jour Psycanalytique. Op. cit., p. 16.

${ }^{169}$ Mannoni, Maud. Educação Impossível. Rio de Janeiro, Francisco Alves, 1988, pp. 24-48.

${ }^{170}$ Idem, p. 28.
} 
pouco aflitiva também para o educador. Por consequiência, o educador parece estar abandonado à sua desordem, a uma solidão no interior de sua prática, que ora obedece a um princípio ora a outro. Todavia, mesmo se esforçando em justificar seu ato em nome da objetividade de um princípio, o adulto, invariavelmente, exerce no ato educativo a repetição das suas pulsões inconscientes.

A impossibilidade de tradução direta dos desejos recalcados (as pulsões inconscientes) resulta na transferência. Lembremos que esta é compreendida como a "atualização da realidade do inconsciente". Ao se encontrar com uma criança, o adulto é remetido às sua próprias questões infantis, ao mesmo tempo que se utiliza dos princípios educacionais vigentes para colocar em ato o que o psiquismo tenciona projetar.

Assim, se antes o autoritarismo na educação tinha como motivador uma revivescência (como numa "vingança") da criança no adulto transferida à criança atual, na educação hesitante de hoje a realização da criança no interior adulto se faz pela esperança de que esta criança se torne no futuro um adulto a quem nada falte. Desta forma, o adulto goza de certa felicidade retrospectiva. Lajonquière diz: "Como sabemos, quando um adulto olha nos olhos de uma criança, e enfoca de fato os olhos da criança ideal, recupera a felicidade que acredita ter perdido, uma vez que lhe retorna do fundo desse olhar sua imagem às avessas." 171

Dentre os limites que a discussão sobre a impossibilidade da educação aponta está a impossibilidade do controle do educador sobre a atuação de seus próprios desejos inconscientes durante o ato educativo. Ao educar, ele depara basicamente com duas crianças: a que está à sua frente e a que foi recalcada em si mesmo. Depara com a criança ideal que gostaria de encontrar no aluno, que o colocaria na posição de adulto ideal, e a criança ideal que gostaria de ter sido. Depara com essas crianças recalcadas em si mesmo que, desde o início da vida, idealizaram uma relação de completude.

Sabemos que a educação se faz através da fala, da superioridade de quem procura convencer o ouvinte pela fala. Contudo, as forças presentes no interior do psiquismo impõem uma "irregularidade" no discurso que é emitido. Sobre isto Kupfer esclarece: "No entanto, a realidade do inconsciente ensina, como já foi dito, que a palavra escapa ao falante. Ao falar, um político ou um educador estará também fadado a se perder, a revelar-se, a ir na direção contrária àquela que seu eu havia determinado. A

\footnotetext{
${ }^{171}$ Lajonquière, Leandro de. Infância e Ilusão (Psico)Pedagógica: Escritos de Psicanálise e Educação. Petrópolis, Vozes, 1999, p. 92.
} 
palavra com a qual esperava submeter, acaba, na verdade, por submetê-lo à realidade de seu próprio desejo inconsciente." 172

Isto vem denunciar que, ao contrário das ilusões pedagógicas sobre a linearidade na relação professor-aluno, o que está em jogo na educação é algo da ordem de um paradoxo: aquele que almeja submeter o outro pelo discurso está submetido no próprio discurso. Daí a impossibilidade do controle, daí a impossibilidade de se desenvolver um método que possibilite atingir as previsões propostas pelas ciências do desenvolvimento.

Falta-nos nesta discussão abordar os outros presentes na figura da criança que o adulto pretende educar.

Freud, em 1914, no texto Algumas Reflexões Sobre a Psicologia Escolar, recorre à teoria do complexo de Édipo para mostrar a relação entre a ambivalência afetiva resultante deste processo e o afeto dirigido pelo aluno ao professor. Lembra Freud que a relação com o pai se inicia por um amor que reflete a necessidade de exaltar o pai, de acreditar no seu poder, na sua bondade e sabedoria. Depois, este pai se revela também o perturbador máximo da vida instintiva. É ele que proclama forte e em bom tom o primeiro de uma série de "nãos". "Daí em diante, os impulsos afetuosos e hostis para com ele persistem lado a lado, muitas vezes até o fim da vida, sem que nenhum deles seja capaz de anular o outro."173

Na segunda metade da infância, o mundo exterior passa a fazer parte da atenção da criança, levando à constatação de que o pai não é mais todo-poderoso, e se estabelece o desligamento de seu primeiro ideal. Freud prossegue dizendo que tudo o que há de admirável e de indesejável na nova geração é determinado por esse desligamento do pai. Depois, Freud faz a relação entre o afeto dirigido ao pai e o afeto ulteriormente dedicado ao educador: "É nessa fase do desenvolvimento de um jovem que ele entra em contato com os professores, de maneira que agora podemos entender a nossa relação com eles. Estes homens, nem todos pais na realidade, tornaram-se nossos pais substitutos. Foi por isso que, embora ainda bastante jovens, nos impressionaram como tão maduros e tão inatingivelmente adultos. Transferimos para eles o respeito e as expectativas ligadas ao pai onisciente de nossa infância e depois começamos a tratá-los como tratávamos nossos pais em casa. Confrontamo-los com a ambivalência que

\footnotetext{
${ }^{172}$ Kupfer, Maria Cristina M. Op. cit., p. 59.

173 Freud, Sigmund. (1914b) Algumas Reflexões Sobre a Psicologia Escolar. Obras Psicológicas Completas de Sigmund Freud, vol. XIII, Rio de Janeiro, Imago, 1988, p. 249.
} 
tínhamos adquirido em nossas próprias famílias e, ajudados por ela, lutamos como tínhamos o hábito de lutar com nossos pais em carne e osso. A menos que levemos em consideração nossos quartos de crianças e nossos lares, nosso comportamento para com os professores seria não apenas incompreensível, mas também indesculpável."174

O professor é depositário das representações inconscientes, de desejos produzidos e recalcados desde as primeiras relações com os progenitores. Ao se relacionar com o professor, o aluno, antes de tudo, está se relacionando com um cenário inconsciente. O sentido atribuído ao professor pelo desejo do aluno não é o mesmo de seu sentido enquanto pessoa. E aquilo que o professor diz ao aluno é escutado através desse sentido que lhe é atribuído. Este é o cenário transferencial em que acontece a educação.

Portanto, no discurso do professor, não só há ausência de domínio sobre o que é falado, pois a palavra escapa ao falante, mas tampouco sobre os efeitos de sua fala no aluno. Vale lembrar que o inconsciente carrega um saber do qual o sujeito (professor e aluno) nada sabe.

A noção de transferência, portanto, vem mostrar que em cada um dos lados da pretensa relação professor-aluno muitos outros estão presentes. Do lado do professor, a sua própria infância, a criança reprimida e a criança idealizada. Do lado do aluno, todos aqueles que já foram produtores e alvos de seus desejos.

Em suma, não está nas mãos dos educadores, nem de quem quer que seja, o controle dos processos psíquicos envolvidos num encontro educativo. Sobre isto, Catherine Millot diz: "Teoria pedagógica alguma permite calcular os efeitos dos métodos com que se opera, pois o que se interpõe entre a medida pedagógica e os resultados obtidos é o Inconsciente do pedagogo e do educando." $" 175$

Se temos claro o que discutimos até então, dizemos que ao mesmo tempo que a noção de transferência aponta para a impossibilidade de relação, ela é também condição para que ocorra o aprender.

A transferência, a intromissão do passado no presente, no interior do ato educativo, vem afirmar a impossibilidade da educação.

\footnotetext{
${ }^{174}$ Freud, Sigmund. (1914b) Algumas Reflexões Sobre a Psicologia Escolar. Op. cit., pp. 285-288.

${ }^{175}$ Millot, Catherine. Op. cit., p. 149.
} 


\section{As Tentativas de se Aplicar o Conceito de Transferência na Ação Educativa}

A noção de transferência trouxe revelações importantes para a compreensão dos limites impostos à educação. Revela a complexidade inerente ao encontro entre duas pessoas, no caso, professor e aluno. O que levaria muitos leitores a se perguntarem sobre a possibilidade de um ajuste entre a prática educativa e o que se conhece sobre a transferência, ou melhor, sobre a possibilidade de uma aplicação desta noção no cotidiano escolar. Podemos responder antecipadamente que tal aplicação direta é irrealizável. E, mais do que isto, é justamente a noção de transferência o pivô da separação entre as práticas analítica e pedagógica.

Uma negativa destas deve buscar consistentes justificativas, principalmente considerando que o próprio Freud sugeriu os benefícios do esclarecimento psicanalítico e a análise pessoal para os educadores: "Se considerarmos agora os difíceis problemas com que defronta o educador - como ele tem de reconhecer a individualidade constitucional da criança, de inferir, a partir de pequenos indícios, o que é que está se passando na mente imatura desta, de dar-lhe a quantidade exata de amor e, ao mesmo tempo, manter um grau eficaz de autoridade -, haveremos de dizer a nós mesmos que a única preparação adequada para a profissão de educador é uma sólida formação psicanalítica. Seria melhor que o educador tivesse sido, ele próprio, analisado, de vez que o certo é ser impossível assimilar a análise sem experimentá-la pessoalmente.”176

Desde que Freud passou a se preocupar mais efetivamente com a aplicação da Psicanálise a outros campos do conhecimento, o tema da conexão entre Psicanálise e Educação tornou-se foco de interesse de muitos estudiosos e admiradores da Psicanálise. Deste grupo numeroso, destacaremos alguns.

Em 1909, o pastor Oskar Pfister submetia à apreciação de Freud dois textos que mostravam um projeto de uma pedagogia que levava em consideração as descobertas psicanalíticas. E, em 1913, Pfister escreve um livro sobre O Método Psicanalítico, voltado para a instrução de educadores e pastores e, mais tarde, em 1921, publica Psicanálise a Serviço dos Educadores. Também nessa linha, o pedagogo Hans Zulliger escreve, em 1921, Psicanálise Para a Escola, e em 1928 A Psicanálise e as Escolas

\footnotetext{
${ }^{176}$ Freud, Sigmund. “Conferência XXXIV - Explicações, Aplicações e Orientações”. In (1933) Novas Conferências Introdutórias Sobre Psicanálise. Op. cit., pp. 147-148.
} 
Novas. Oskar Pfister e Hans Zulliger são dois representantes de um grupo que, no início do século XX, estava interessado em formar uma nova disciplina, a Pedagogia Psicanalítica.

Mesmo reconhecendo a importância e, de alguma forma, acompanhando e aprovando os esforços demonstrados por esses autores, Freud, com certa parcialidade, movido pelo orgulho de pai, atribui na Conferência XXXIV - Explicações, Aplicações e Orientações, publicada em 1933, (que leva o nome de conferência, pois o estilo oral do texto é, segundo Freud, somente um artifício de imaginação) o mérito destes esforços à sua filha Anna Freud: "Existe um tema, todavia, que não posso deixar passar tão facilmente - assim mesmo, não porque eu entenda muito a respeito dele, e nem tenha contribuído muito para ele. Muito pelo contrário: aliás, desse assunto ocupei-me muito pouco. Devo mencioná-lo porque é da maior importância, é tão pleno de esperanças para o futuro, talvez seja a mais importante de todas as atividades da análise. Estou pensando nas aplicações da Psicanálise à Educação, à criação da nova geração. Sintome contente com o fato de pelo menos poder dizer que minha filha, Anna Freud, fez desse estudo a obra de sua vida e, dessa forma, compensou a minha falta."177

Anna Freud, assim como Melanie Klein na Inglaterra, idealizava, tal como Freud expressa em citação anterior, uma educação psicanaliticamente orientada que evitasse a instalação da neurose. Portanto, seus trabalhos pretendiam transmitir a teoria psicanalítica a pais e professores.

O texto de Janine Filloux Sobre o Conceito de Transferência no Campo Pedagógico ${ }^{178}$ traz uma análise minuciosa dos escritos resultantes do movimento da pedagogia psicanalítica entre 1926 e 1937. Durante esses onze anos, diversos autores publicaram seus trabalhos na Revista de Pedagogia Psicanalítica, em Stuttgart e Viena. No final deste período de publicação, em 1936, acontece o décimo segundo Congresso Internacional de Psicanálise, e a ilusão de uma pedagogia psicanalítica começa a revelar-se. Alguns analistas de crianças e até mesmo o pedagogo Hans Zulliger enfatizam os equívocos e mal-entendidos de uma aplicação pedagógica da teoria analítica, destacam os perigos que podem resultar do trabalho do pedagogo com o material psíquico inconsciente e analisam as dificuldades e conflitos que derivam do abandono de uma posição educativa tradicional. Apesar de os educadores estarem

\footnotetext{
${ }^{177}$ Freud, Sigmund. "Conferência XXXIV - Explicações, Aplicações e Orientações”. In (1933) Novas Conferências Introdutórias Sobre Psicanálise. Op. cit., pp. 144-145.

${ }^{178}$ Filloux, Janine. "Sur le Concept de Transfert Dans le Champ Pédagogique". In Revue Française de Pédagogie, 87. Abril-maio-junho de 1989, pp. 59-75.
} 
envolvidos pelos efeitos do psiquismo, não há contato direto possível com o mesmo. Chegam a afirmar que os conhecimentos psicanalíticos não podem significar nenhuma ajuda para o pedagogo e nenhuma intervenção psicanalítica poderia ser feita por ele.

Em Juventude Desorientada de Aichhorn, pode-se verificar a idéia de que a transferência positiva, representada pela manifestação de afetos positivos em relação ao professor, seria a condição para a educação. ${ }^{179}$ Lembrando a exposição de Freud sobre o assunto, tanto a transferência positiva (amor, confiança e submissão à figura do analista) quanto a negativa (desconfiança e hostilidade dirigidas ao analista) são produtos da resistência e ambas fazem parte do trabalho de análise de um mesmo paciente. Se transpusermos isto para o ambiente escolar, diríamos que a transferência positiva seria o que mantém o aluno confiante no saber do professor e disposto a aproximar-se dele; e a transferência negativa seria a desconfiança de que ao professor faltam saberes, portanto, faz o aluno afastar-se do professor. Apesar de certa insegurança em tal transposição, ela vem confirmar um movimento de aproximação (dependência) e afastamento (abandono) inerente e necessário à educação.

Então, mesmo sabendo que é a transferência que está em questão no aprender, não seria prudente recomendar aos professores que favoreçam a transferência positiva, até porque não existe qualquer possibilidade desse manejo.

Solicitado a romper com a atitude educativa clássica de ocupar o lugar de quem possui a palavra para a atitude mais passiva de escutar, de expectativa, de tolerância, típica do analista, para mobilizar a capacidade de aprender, o pedagogo estaria sendo levado a assumir um papel que não lhe pertence, tampouco lhe seria possível desempenhar. As condições da prática educativa não constituem um quadro adequado à análise dos conflitos psíquicos. Também podemos encontrar tal dedução em Freud: “A segunda lição tem uma aura um tanto conservadora. Afirma-se no sentido de que o trabalho da educação é algo sui generis: não deve ser confundido com a influência psicanalítica e não pode ser substituído por ela. A psicanálise pode ser convocada pela educação como meio auxiliar de lidar com uma criança, porém não constitui um substituto apropriado para a educação. Tal substituição não só é impossível em fundamentos práticos, como também deve ser desaconselhada por razões teóricas." ${ }^{180}$

\footnotetext{
179 Aichhorn, August. "Juventude Desorientada". In Cifali, Mireille; Imbert, Francis. Freud $e$ a Pedagogia. São Paulo, Edições Loyola, 1999, p. 69.

${ }^{180}$ Freud, Sigmund. Prefácio à Juventude Desorientada. Obras Psicológicas Completas de Sigmund Freud, vol. XIX, Rio de Janeiro, Imago, 1976, p. 342.
} 
Os fundamentos práticos e as razões teóricas apóiam-se justamente na noção de transferência. Já sabemos que a transferência que ocorre no contexto analítico é desencadeada pela "promessa" de cura embutida na figura do analista, pelo fato de o paciente supor no analista o saber sobre aquilo que lhe falta. Esta é a condição inicial para que se estabeleça a neurose de transferência, quando o paciente reedita seus afetos provenientes de relações anteriores, dirigindo-os para o analista. É sobre tais transferências de afeto que a análise é conduzida.

Existem, portanto, condições específicas para que a neurose de transferência ocorra, possibilitando ao trabalho analítico substituir a rememoração na repetição pela interpretação e construção. Tal substituição é operada pela palavra. $\mathrm{O}$ trabalho da cura analítica consiste em tornar possível o advento de uma palavra no lugar do sintoma.

A transferência, como objeto de decifração, é a ferramenta da análise. Ela reanima os afetos presentes na infância, os desejos incestuosos e a proibição do incesto, isto é, a situação edipiana e seus efeitos.

Devemos acrescentar, porém, que as manifestações transferenciais não são repetições literais, mas equivalentes simbólicos do que se transfere. Isto nos leva a deduzir duas coisas: primeira, que há algo da ordem de uma transformação, poderíamos dizer, sobre algo de atual nas relações; segunda, que não há transparência nas manifestações transferenciais, o que não permite a decifração direta do sentido das mesmas. Não podemos ter acesso aos conflitos inconscientes, exceto na ação própria da análise. Por isso, a transferência não pode ser tratada na ação educativa. Isto quer dizer que, mesmo sabendo da existência dos fenômenos transferenciais, o educador não deve fornecer interpretações, muito menos acreditar que possa manipular, à sua vontade, a transferência em favor da educação.

Como expressou Janine Filloux: "Renunciar à ilusão de estar na origem dos motivos afetuosos e hostis que lhes são endereçados, tal é a ferida narcísica que a teorização freudiana dos fenômenos de transferência inflige nos docentes." ${ }^{181}$ Divulgar a existência da transferência aos educadores significa levá-los a compreender e reconhecer a existência dos processos psíquicos inconscientes e suas leis e, como fenômeno afetivo universal, seu papel na promoção da socialização. Por outro lado, significa também aceitar a impossibilidade de seu domínio.

\footnotetext{
${ }^{181}$ Filloux, Janine. "Sur le Concept de Transfert Dans le Champ Pédagogique". In Revue Française de Pédagogie, 87. Abril-maio-junho de 1989, p. 61.
} 


\section{A “Utilidade” do Saber Psicanalítico na Educação}

Iniciaremos essa parte de nossa discussão a partir de uma crítica à leitura psicanalítica da Educação. Em seu trabalho intitulado Relação Professor-Aluno: Uma Leitura Institucional, Júlio Roberto Groppa Aquino interpreta a impossibilidade de aplicação prática da Psicanálise à Educação como uma impossibilidade de contribuição entre os campos. Destacaremos alguns trechos que demonstram os enganos de sua interpretação, ou melhor, uma dificuldade na compreensão da teoria psicanalítica.

Aquino entende que um dos fatores que distanciam a Psicanálise da Educação seria um suposto monopólio dos psicanalistas sobre o manejo teórico, técnico e prático do inconsciente e isto se caracterizaria numa recusa ou evasão quanto a um possível entrelaçamento do campo psicanalítico a outros campos do conhecimento. ${ }^{182}$ Sabemos, entretanto, que a discussão analítica se esforça em mostrar que não há manejo possível do inconsciente nem para o analista, cujo trabalho é de interpretar a posteriori seus efeitos, nem tampouco para qualquer outro profissional. À Psicanálise, como a compreendemos, interessa mostrar justamente o caráter não manejável do inconsciente e, para isto, o domínio teórico encontra-se disponível a quem possuir interesse neste campo do saber.

Sua crítica pesa também sobre a noção de "intersubjetividade" utilizada por alguns psicanalistas: “A própria noção de 'intersubjetividade' adotada implica, a nosso ver, uma ambigüidade, uma vez que tenta situar a 'causação' da subjetividade no entrecruzamento identificatório de relações virtuais marcadas por um esquema de gregarismo. (...) Não obstante, a dicotomização dos lugares (semelhante à do enfoque psicológico-interacionista) parece persistir nas formulações dos psicanalistas. Antes, $\underline{\text { a }}$ auteridade permanece polarizada, preservando-se um esquema de polaridades dadas, só que agora desconhecidas - o que revela uma espécie de mão-dupla, mas cega, na relação professor-aluno."

A noção de "intersubjetividade" é alvo de uma discussão ainda não terminada dentro da Psicanálise, portanto, não reflete a opinião de todos os psicanalistas. $\mathrm{O}$ termo

\footnotetext{
${ }^{182}$ Aquino, Júlio R. G. Relação Professor-Aluno: Uma Leitura Institucional. Tese de Doutorado, Instituto de Psicologia, Universidade de São Paulo, São Paulo, 1995, p. 49.

${ }^{183}$ Aquino, Júlio R. G. Relação Professor-Aluno: Uma Leitura Institucional. Op. cit., p. 53.
} 
sugere a formação subjetiva de um sujeito pelos efeitos causados pela subjetividade de outro sujeito. No entanto, lembremos que num encontro entre dois sujeitos - apesar de cada um se dirigir ao outro que está à sua frente - uma relação imaginária se estabelece; pois antes de tudo cada um se relaciona com os afetos provenientes de relações anteriores que, agora, são projetados nesse outro. Bem, mas o que nos interessa principalmente é que a discussão feita por Aquino demonstra uma leitura sobre a relação professor-aluno, do ponto de vista psicanalítico, que permanece, ela própria, numa instância imaginária. A Psicanálise não nega que as identificações existam no nível imaginário e que ocorra uma atualização nas relações atuais dos sujeitos. Portanto, a relação professor-aluno não pode ser considerada cega neste sentido. Aliás, esta relação citada por Aquino é acessível a qualquer leitor. Entretanto, a Psicanálise se ocupa em desvendar uma outra instância que, aí sim, nos coloca na condição de cegos: a instância simbólica do inconsciente.

Ainda sobre a noção de "intersubjetividade": "Por fim, outra ressalva à noção de intersubjetividade em questão advém das posições atribuídas ao professor e ao aluno. $\mathrm{O}$ primeiro aparece como já constituído, enquanto o segundo, em constituição. Ambos, impassíveis 'dublets' do desejo do outro, estariam fadados ao malogro, feitos ecos no abismo da ignorância. A possibilidade do encontro fica, enfim, ao acaso." ${ }^{184}$ Estas afirmações distanciam-se muito das proposições psicanalíticas. Em primeiro lugar, o conceito de sujeito presente na Psicanálise vem justamente diferenciar-se do conceito de indivíduo empregado pela ciência, no sentido mesmo que, sendo sujeito do desejo, está fadado a buscar, indefinidamente, saber sobre o desejo. Esta condição empurra o sujeito para a vida, para os encontros com o outro, portanto está em permanente estado de vir a ser. Sendo assim, nunca será um sujeito já constituído, mesmo sendo um adulto (no caso do professor). E ainda devemos ressaltar o emprego, por Aquino, dos termos "ignorância" e "encontro". O sentido que o autor confere à ignorância é o mesmo daquele referente aos saberes instituídos (da cultura); porém, a "ignorância" sugerida pela Psicanálise refere-se ao próprio desejo, este que é levado ao encontro com o outro e que consiste num "desejo de saber sobre o desejo". Este desejo fundado pela castração, e cujo registro da falta conduz o sujeito à busca do objeto $a$ (já mencionado no segundo capítulo), não é realizado, pois não termina num único objeto. É o querer saber sobre o

${ }^{184}$ Idem, p. 54. 
desejo e o não querer saber que não há saber sobre o desejo que impulsiona o sujeito para a transferência nas relações.

E no que se refere ao "encontro", existe sim o que podemos chamar de encontro imaginário, o das identificações; porém, ao encontro imaginário fogem as questões inconscientes da subjetividade de cada um, o cerne das identificações, as representações, desejos e afetos recalcados do inconsciente.

Finalizando nossa leitura do trabalho de Júlio Aquino, abordaremos uma questão central para nós. Referindo-se à reflexão psicanalítica sobre a relação professor-aluno à luz do conceito de transferência, ele afirma: "Se, à primeira vista, os autores psicanalistas nos ofertam dispositivos para uma desmontagem da dinâmica interna da relação professor-aluno, em seguida eles nos interditam o objeto que supúnhamos remontar. E esta parece ser a peça-chave que nos faltava para a compreensão do eixo imaginário condutor do enfoque psicanalítico: a ressonância analógica e, depois, a interdição." 185

O interesse da Psicanálise não nos parece ser o de estabelecer apenas uma analogia entre sua teoria e uma realidade; pretende, sim, trazer à luz os fenômenos inconscientes presentes nas relações entre os seres humanos. Tornar compreensível a dinâmica psíquica não significa a construção de estratégias para mudar, controlar, desfazer e refazer a realidade humana. No que se refere à constatação e compreensão da transferência no ato educativo, diríamos em primeiro lugar que psicanalisar não é o papel do educador; segundo, que a validade de uma teoria não se relaciona com as prescrições de manejo da realidade; e, em último lugar, que conclusões como esta, de Aquino, partem de uma concepção utilitarista das produções de diferentes campos do conhecimento. Acrescentamos que tal concepção utilitarista é muito comum no campo da Pedagogia, levando-a a acreditar na possibilidade de transformar toda teoria em prática, assim como fez com as teorias de Piaget. Diríamos que da teoria de Piaget não se deduz uma intervenção como os pedagogos acreditam.

Diferentemente do que diz Júlio Aquino, os "psicanalistas da educação" não se resignam diante do que se chama irredutibilidade da Psicanálise. ${ }^{186}$ Caso contrário, não estariam produzindo tantos trabalhos no interior da conexão Psicanálise e Educação.

\footnotetext{
185 Aquino, Júlio R. G. Relação Professor-Aluno: Uma Leitura Institucional. Op. cit., p. 54.

${ }^{186}$ Aquino, Júlio R. G. Relação Professor-Aluno: Uma Leitura Institucional. Op. cit., p. 54.
} 
Para os psicanalistas, o que se mostra irredutível, indomável é a realidade do inconsciente. Isto a Psicanálise revela aos educadores.

$O$ que fazer, então, com a descoberta psicanalítica sobre o inconsciente? $O$ que fazer com a realidade transferencial nas relações?

A Psicanálise não diz o que deve ser feito, mas reflete sobre o que tem sido feito na educação. Diríamos que, de posse dos conhecimentos psicanalíticos, o educador poderá, principalmente, redimensionar o valor atribuído aos métodos, questionar-se sobre a ilusão do controle da educação.

A noção de transferência evidencia a responsabilidade do educador na formação do aluno, a necessidade de que sustente a posição de sujeito suposto saber. No momento que o professor recebeu os ensinamentos sobre a cultura, herdou uma dívida: ele deve perpetuar esta cultura, portanto tem o dever de transmiti-la. O importante é que a noção de transferência vem revelar o professor como responsável, por excelência, pela aprendizagem e a ineficiência dos métodos como meio de controle da aprendizagem. Os métodos são ferramentas alternativas na efetivação da transmissão, na interpretação dos signos pelo professor.

Para finalizarmos, podemos dizer que não é pelo fato de a Psicanálise ter revelado a impossibilidade da educação que ela é detentora do saber sobre os caminhos da possibilidade. A educação sempre será impossível, embora mais de uma educação singular continuem possíveis. 


\section{CONSIDERAÇÕES FINAIS}

“ - Devemos, pois, se tudo isto for verdade, concluir o seguinte: a educação não é de nenhum modo o que alguns proclamam que ela seja; pois pretendemos introduzi-la na alma, onde ela não está, como alguém que desse a visão a olhos cegos."

(Platão, 429-347 A.C.) 


\section{CONSIDERAÇÕES FINAIS}

Como pudemos ver no primeiro capítulo deste trabalho, hoje, os educadores fazem questão de não se reconhecerem como autoritários, deixam este estigma aos chamados educadores tradicionais (considerados repressores ultrapassados) e se definem, quase sempre, construtivistas / interacionistas. Mostram-se atentos às formulações da Psicologia e delas procuram extrair os métodos sempre "mais eficazes" que aqueles que se vinham empregando. Fala-se insistentemente em "saber sobre a fase de desenvolvimento em que o aluno se encontra e estimulá-lo", "trabalhar a partir da realidade do aluno", "motivá-lo", "conhecer os seus interesses”, enfim, uma série de prescrições aos educadores, no sentido de adequar a intervenção do professor à realidade da maturação cognitiva e emocional do aluno, seus interesses e motivações.

Vemos a educação escolar e familiar condicionadas a pensar conforme aquilo que dita a ciência psicológica, já que, desta forma, supõem elas, estarão respeitando a "essência" do ser humano, a "sua natureza". O adulto - como educador, como autoridade diante da criança - se exime dessa posição, esperando que a ciência se responsabilize pelos erros e acertos de uma educação. Assim sendo, enquanto espera as instruções do psicólogo, do psicopedagogo ou do manual de educação, o adulto - que carrega uma diferença pelo fato de ter nascido primeiro - hesita e se destitui da responsabilidade de transmitir à criança o que a diferença inerente entre eles vem representar: o conhecimento sobre as produções culturais da humanidade e sobre os caminhos possíveis para viver na sociedade.

A medida certa da adequação dos estímulos oferecidos pelo educador à "natureza" cognitiva e afetiva do aluno caracterizaria, como vimos, o que se pensa sobre uma relação psicologicamente ajustada entre professor e aluno. Verifica-se, sem dúvida, uma freqüente preocupação em se descobrirem e dominarem as "chaves" da relação educativa. O sucesso educativo depende, segundo os pedagogos atuais, dessa "relação adequada". Porém, quando os pedagogos percebem que a tentativa de ajuste na relação não levou ao resultado esperado, apresentam as seguintes justificativas: a ineficácia do método empregado ou do professor (para o qual se sugere um curso de reciclagem) ou, 
ainda, o atraso na maturação do aluno (que, por sua vez, é enviado a uma clínica psicológica ou psicopedagógica). Portanto, um dos lados da relação estava desajustado, ou seja, para a Pedagogia o problema reside na falta de adequação da intervenção do professor à etapa de desenvolvimento em que o aluno se encontra, ou vice-versa.

Nossa crítica recai justamente sobre a ilusão pedagógica da existência de uma adequação na relação. E, tratar a tese da adequação como uma ilusão não significa dizer que o adulto não reflita e decida sempre artificialmente sobre como atuar e o que ensinar, mas sim, aponta para a ilusão de um ajuste psicológico da relação.

Foi através do conceito de transferência que pudemos justificar nossa crítica. Ele vem nos mostrar duas importantes realidades no interior do ato educativo, a saber: a impossibilidade da relação e o aprender enquanto derivado da transferência instalada entre professor e aluno.

Compreender basicamente o que e por que o sujeito transfere demanda uma incursão na teoria psicanalítica de Freud e de Lacan sobre o funcionamento do aparelho psíquico e a constituição do sujeito.

Vimos que o psiquismo humano se funda a partir do registro da falta, pois, antes disso, ele estava confundido com um outro (com freqüência, a mãe), o que chamamos de "célula narcísica". Com a intromissão de um terceiro, evidencia-se a castração (a incompletude de ambos), estabelece-se um corte na célula narcísica e nasce daí um novo sujeito, um ser em falta, um sujeito do desejo. A esta passagem pelo registro da falta, ou ainda, pelo registro da castração dá-se o nome de complexo de Édipo.

Marcado pela falta, quando o sujeito se endereça a outro, supõe neste outro o saber sobre seu desejo, sobre isto que lhe falta (o objeto $a$ ). O que o sujeito procura no outro é, de certa forma, recuperar o estado mítico de completude; o sujeito espera que este outro lhe ofereça o reconhecimento, em última instância, o amor. Dizemos que um se aproxima pelo amor, enquanto o outro não sabe o que tem (lembremos do amor de Alcibíades por Sócrates), movendo o sujeito ao encontro de outros. É, portanto, a busca pelo saber sobre o desejo que faz o sujeito apostar na transferência. No entanto, não há saber sobre o desejo e cada sujeito é, permanentemente, um sujeito desejante.

A noção de transferência vem revelar a complexidade do encontro entre dois sujeitos, pois nele o sujeito atualiza a realidade de seu inconsciente. Por isso, a noção de transferência revela aos pedagogos de hoje a impossibilidade da relação. O que existe, sim, é uma relação imaginária e isto significa dizer que, por encontrar-se submetida à realidade psíquica singular de cada sujeito, nunca haverá uma relação simétrica; haverá 
sempre muito mais conteúdo na realidade deste encontro do que dele se pode apreender. De fato, nesta "relação" entre supostos "dois lados" há um conjunto inumerável de outros.

Procuramos descrever, neste trabalho, o "ambiente" transferencial em que ocorre o ato educativo. Mesmo que o professor saiba, ou não, sobre a transferência, ela é inevitável e, mais do que isso, ela está implicada no aprender.

Quando o aluno se endereça ao professor é porque, inconscientemente, supõe nele o saber sobre seu desejo. Aliás, são os pais que introduzem a criança na transferência com o professor, pois foram eles que sugeriram esta aposta quando a levaram para a escola. A criança vê no professor a possibilidade de realizar o desejo dos pais e supõe que estes estejam dizendo que é o professor quem tem o saber sobre como se torna adulto (em relação ao desejo). Para o aluno, o professor é o Sujeito Suposto Saber. Hoje, por acreditarem na superioridade das teorias do desenvolvimento, nos manuais e especialistas em crianças, parece que esta aposta no saber do professor fica prejudicada. Assim, diríamos que, para os próprios educadores (dentre eles, os pais), a escola tem perdido seu espaço e, de certa forma, seu valor.

Mesmo assumindo a posição de sujeito suposto saber atribuída pelo aluno, o professor, como já foi dito em outro momento, deve renunciar à posição narcísica de ter todo o saber sobre o aluno e posicionar-se como mediador entre o aluno e o conhecimento. Desta forma, permitirá que o aluno aprenda e permaneça desejando saber, cumprindo os movimentos de aproximação (dependência) e afastamento (superação). Na relação imaginária, interpreta os signos para o aluno, revela os segredos da matemática, da língua, da pátria... À medida que o aluno se apropria do conhecimento, vai tecendo laços com uma tradição e, pertencendo a esta tradição, vai adquirindo uma identidade, portanto, existindo.

O estudo do ato educativo a partir das proposições psicanalíticas sobre a noção de transferência possibilitou-nos identificar algumas ilusões e enganos no tratamento que a Pedagogia atual vem dispensando à educação.

Lembremos que os educadores de hoje pensam que "devem ser adequados" na "relação" com o aluno e que esta adequação é ditada pela ciência psicológica. Isto faz o educador colocar em suspenso qualquer atitude em nome da natureza professada pela teoria e destituir-se do papel de autoridade. Em outras palavras, evitando ser inadequados, acabam, muitas vezes, posicionando-se como meros espectadores desta suposta natureza de seus alunos. Sendo assim, destituem-se da posição de sujeito 
suposto saber atribuída pelo aluno, desfazendo a primeira condição da aprendizagem: a dependência inicial do aluno em relação ao professor. Tendo em vista que o sujeito suposto saber é o princípio constitutivo da transferência, é supondo no professor o saber sobre seu desejo (saber impossível) que o aluno se coloca em condição de participar da transmissão dos saberes constituídos (saberes possíveis). Não assumindo a responsabilidade pela transmissão da cultura acumulada pela civilização, o educador retira de cena o que levaria o aluno a apostar na sua figura, como meio de alcançar o saber sobre o lugar que ocupa no mundo.

Por outro lado, esta mesma natureza, cientificamente professada, coloca o educador diante de uma pretensa certeza sobre o aluno e aquilo de que ele necessita. Acredita que, com o domínio da ciência sobre a criança ou sobre a "relação", pode dizimar a falta, atingir a completude idealizada. Pode-se dizer que, se no passado se ensinava em nome do ideal de uma moral religiosa, hoje a Pedagogia ensina em nome do ideal psiconaturalista. Melhor dizendo, a Pedagogia acredita saber sobre o bem-estar no mundo e ser capaz de criar indivíduos mais felizes. Esta certeza faz com que aposte na produção de seres humanos cognitiva e emocionalmente ideais. Assim, pratica o que Maud Mannoni chama de perversão do dispositivo educativo, a perversão da autoridade tal como fez o Dr. Schreber. Perverte a transferência enquanto a utiliza, a fím de conformar os alunos a um ideal previamente estabelecido. Propaga um discurso sedutor, não menos autoritário, que termina por alienar o aluno numa promessa.

Como vimos, hoje, o educador transita entre o nada saber (pois pensa que o conhecimento está submetido à natureza do aluno) e o tudo saber sobre o que quer uma criança, e como fazê-la feliz. Pode-se dizer que em ambos os aspectos a Pedagogia atual peca pela intenção de apagar a diferença. No primeiro, a diferença é apagada à medida que o professor se infantiliza, não assume a posição de autoridade, de sujeito suposto saber, por acreditar ser essa posição contra a "natureza" do aluno, como diz Lajonquière: "Nos dias que correm, supõe-se que o adulto deva se eclipsar renunciando à sustentação do ato educativo - ou seja, renunciar à possibilidade de que se desdobre a diferença que se aninha entre ele e uma criança - para assim vir supostamente a produzir crianças felizes e criativas, sintonizadas com o 'futuro'. A Pedagogia vem professando semelhante ilusão há quase um século e, por outro lado, o cotidiano escolar, embora ainda apresente pontos de resistência, passa a estar tencionado a partir desse 
ideário." 187 No segundo, tenta-se eliminar a diferença ao acreditar na possibilidade de conformar os alunos a um ideal (o Ideal do Ego) que traria a felicidade aos futuros adultos e que converteria os pedagogos em Ego Ideal, a própria realização da felicidade, sabedores do bem-estar no mundo.

É basicamente sobre este engano que a Psicanálise vem alertar os educadores. Vem revelar a diferença que diz da singularidade de cada sujeito, portanto a diferença entre aquilo que se tenciona atingir no sujeito e a realidade do que se atinge numa pretensa relação. Mais ainda, a Psicanálise nos fala sobre o impossível de se viver na plenitude como condição para se viver na sociedade, isto é, a felicidade está fora da sociedade e para que ela se mantenha, as realizações são adiadas ou substituídas. Não há como fazer retornar àquele momento mítico de realização total, de completude. Por isso, a Pedagogia não pode cumprir sua promessa. A realidade da vida civilizada submete os sujeitos a uma condição: a falta a ser, em suma, a diferença.

Arriscamos dizer que aí reside a origem do mal-estar pedagógico, a negação daquilo que marca o ser humano: a angústia, a falta que leva o sujeito a transferir para outro o saber sobre o desejo. Desta negação resultam as buscas infrutíferas de controle através de métodos cientificamente fundamentados e de uma relação psicologicamente adequada.

Para finalizar, lembramos mais uma vez que o Sujeito Suposto Saber é o princípio constitutivo da transferência e que a Pedagogia de hoje posiciona-se de forma a invalidá-lo e pervertê-lo. Deduzimos daí que a transferência é algo que incomoda os pedagogos de hoje. De fato, ela inflige ao educador a renúncia da ilusão de estar na origem dos motivos afetuosos e hostis que lhe são endereçados e, então, revela a impossibilidade de uma relação simétrica.

$\mathrm{Na}$ história pregressa do conceito de transferência, soubemos que Breuer não sustentou os efeitos da transferência de Anna O.. Arriscamos dizer que Breuer supunha garantir, com o domínio do método catártico, a relação mais adequada entre médico e paciente. Ao descobrir-se objeto dos afetos de Anna O., e desconhecendo o fato de ele próprio não estar na origem destes afetos, Breuer temeu a impossibilidade do controle da transferência.

\footnotetext{
${ }^{187}$ Lajonquière, Leandro de. Infância e Ilusão (Psico)Pedagógica: Escritos de Psicanálise e Educação, Petrópolis, Vozes, 1999, p. 27.
} 
Enfim, diante da recusa da realidade transferencial pela Pedagogia, concluímos que tal recusa repousa no fato de a Pedagogia atual ter tanto medo da transferência quanto Breuer.

\section{BIBLIOGRAFIA}

AQUINO, J. R. G. Relação Professor-Aluno: Uma Leitura Institucional. Tese de Doutorado, Instituto de Psicologia, Universidade de São Paulo, São Paulo, 1995.

ARENDT, H. Entre o Passado e o Futuro. São Paulo, Ed. Perspectiva, 1972.

BENOIT, H. Sócrates: O Nascimento da Razão Negativa. São Paulo, Ed. Moderna, 1996.

BREUER, J.; FREUD, S. (1893-5) Estudos Sobre a Histeria. Edição Standard Brasileira das Obras Psicológicas Completas de Sigmund Freud, vol. II, Rio de Janeiro, Imago, 1995.

CIFALI, M. Le Lien Éducatif: Contre-Jour Psychanalytique. Paris, Presses Universitaires de France, 1994.

CIFALI, M.; IMBERT, F. Freud e a Pedagogia. São Paulo, Edições Loyola, 1999.

FILlOUX, J. Sur le Concept de Transfert dans le Champ Pédagogique. In Revue Française de Pédagogie. $\mathrm{N}^{\mathrm{o}}$ 87, 1989, pp. 59-75.

FREUD, S. (1886) Relatório sobre Meus Estudos em Paris e Berlim. Edição Standard Brasileira das Obras Psicológicas Completas de Sigmund Freud, vol. I, Rio de Janeiro, Imago, 1988.

. (1893) Charcot. Edição Standard Brasileira das Obras Psicológicas Completas de Sigmund Freud, vol. III, Rio de Janeiro, Imago, 1994.

. (1900-1901) A Interpretação de Sonhos I e II. Edição Standard Brasileira das Obras Psicológicas Completas de Sigmund Freud, vols. IV e V, Rio de Janeiro, Imago, 1987.

(1905a) Fragmento da Análise de Um Caso de Histeria. Edição Standard Brasileira das Obras Psicológicas Completas de Sigmund Freud, vol. VII, Rio de Janeiro, Imago, 1988.

. (1905b) Três Ensaios Sobre a Teoria da Sexualidade. Edição Standard Brasileira das Obras Psicológicas Completas de Sigmund Freud, vol. VII, Rio de Janeiro, Imago, 1988. 
(1907) O Esclarecimento Sexual das Crianças. Edição Standard Brasileira das

Obras Psicológicas Completas de Sigmund Freud, vol. IX, Rio de Janeiro, Imago, 1988. . (1910a) Cinco Lições de Psicanálise. Edição Standard Brasileira das Obras

Psicológicas Completas de Sigmund Freud, vol. XI, Rio de Janeiro, Imago, 1970.

(1910b) As Perspectivas Futuras da Terapêutica Psicanalítica. Edição Standard

Brasileira das Obras Psicológicas Completas de Sigmund Freud, vol. XI, Rio de Janeiro, Imago, 1970.

(1912) A Dinâmica da Transferência. Edição Standard Brasileira das Obras

Psicológicas Completas de Sigmund Freud, vol. XII, Rio de Janeiro, Imago, 1988.

. (1913) O Interesse Científico da Psicanálise. Edição Standard Brasileira das

Obras Psicológicas Completas de Sigmund Freud, vol. XIII, Rio de Janeiro, Imago, 1995.

(1914a) Recordar, Repetir e Elaborar. Edição Standard Brasileira das Obras

Psicológicas Completas de Sigmund Freud, vol. XII, Rio de Janeiro, Imago, 1988.

(1914b) Algumas Reflexões sobre a Psicologia do Escolar. Edição Standard

Brasileira das Obras Psicológicas Completas de Sigmund Freud, vol. XIII, Rio de Janeiro, Imago, 1995.

(1914c) A História do Movimento Psicanalítico. Edição Standard Brasileira das

Obras Psicológicas Completas de Sigmund Freud, vol. XIV, Rio de Janeiro, Imago, 1988.

(1915) Observações sobre o Amor Transferencial. Edição Standard Brasileira das Obras Psicológicas Completas de Sigmund Freud, vol. XII, Rio de Janeiro, Imago, 1988.

(1917) Conferências Introdutórias sobre Psicanálise. Edição Standard

Brasileira das Obras Psicológicas Completas de Sigmund Freud, vol. XVI, Rio de Janeiro, Imago, 1976.

. (1920) Além do Princípio de Prazer. Edição Standard Brasileira das Obras

Psicológicas Completas de Sigmund Freud, vol. XVIII, Rio de Janeiro, Imago, 1988.

- (1924a) Carta a Le Disque Vert. Edição Standard Brasileira das Obras

Psicológicas Completas de Sigmund Freud, vol. XIX, Rio de Janeiro, Imago, 1976.

. (1924b) Um Estudo Autobiográfico. Edição Standard Brasileira das Obras

Psicológicas Completas de Sigmund Freud, vol. XX, Rio de Janeiro, Imago, 1988. 
(1925) Prefácio a Juventude Desorientada, de Aichhorn. Edição Standard Brasileira das Obras Psicológicas Completas de Sigmund Freud, vol. XIX, Rio de Janeiro, Imago, 1976.

- (1933) Novas Conferências Introdutórias sobre Psicanálise e Outros

Trabalhos. Edição Standard Brasileira das Obras Psicológicas Completas de Sigmund Freud, vol. XXII, Rio de Janeiro, Imago, 1994.

. (1935a) Pós-Escrito (de Um Estudo Autobiográfico). Edição Standard Brasileira

das Obras Psicológicas Completas de Sigmund Freud, vol. XX, Rio de Janeiro, Imago, 1988.

(1935b) As Sutilezas de Um Ato Falho. Edição Standard Brasileira das Obras Psicológicas Completas de Sigmund Freud, vol. XXII, Rio de Janeiro, Imago, 1994.

(1937) Análise Terminável e Interminável. Edição Standard Brasileira das

Obras Psicológicas Completas de Sigmund Freud, vol. XXIII, Rio de Janeiro, Imago, 1988.

GOLDGRUB, F. Mito e Fantasia: O Imaginário segundo Lévi-Strauss e Freud. São Paulo, Ed. Ática, 1995.

JONES, E. Vida e Obra de Sigmund Freud. Vol. I, Rio de Janeiro, Zahar Editores, 1970.

KUPFER, M. C. M. Freud e a Educação: O Mestre do Impossível. São Paulo, Ed. Scipione, 1989.

LACAN, J. O Seminário, livro 1: Os Escritos Técnicos de Freud. Rio de Janeiro, Jorge Zahar Editor, 1979.

O Seminário, livro 8: A Transferência. Rio de Janeiro, Jorge Zahar Editor, 1992.

O Seminário, livro 11: Os Quatro Conceitos Fundamentais da Psicanálise. Rio de Janeiro, Jorge Zahar Editor, 1998.

. Escritos. São Paulo, Editora Perspectiva, 1978.

LAGACHE, D. A Transferência. São Paulo, Martins Fontes, 1990.

LAJONQUIÈRE, L. de. De Piaget a Freud: Para Repensar as Aprendizagens. A (Psico)Pedagogia entre o Conhecimento e o Saber. Petrópolis, Vozes, 1992. . (Psico)Pedagogia, Psicanálise e Educação. Uma Aula Introdutória.

In Estilos da Clínica: Revista sobre a Infância com Problemas. São Paulo, Instituto de Psicologia da USP, Pré-Escola Terapêutica Lugar de Vida, ano 3, número 5, 1998. Infância e Ilusão (Psico)Pedagógica: Escritos de Psicanálise e Educação. Petrópolis, Vozes, 1999. 
. Freud, L'Éducation et Les Enfants: Entre la Psychanalyse et le Politique. In Les États Généraux de la Psychanalyse. Paris, La Sorbonne, 2000.

LAPlANCHE, J.; PONTALIS, J.-B. Vocabulário da Psicanálise. São Paulo, Martins Fontes, 1992.

LÉVI-STRAUSS, C. As Estruturas Elementares do Parentesco. Petrópolis, Vozes, 1976.

PEREIRA, M. R. O Relacional e seu Avesso na Ação do Bom Professor. In A Psicanálise Escuta a Educação. Eliane M. T. Lopes (org.), Belo Horizonte, Autêntica, 1998.

MANNONI, M. Educação Impossível. Rio de Janeiro, Francisco Alves, 1988.

MANNONI, O. Freud: Uma Biografia Ilustrada. Rio de Janeiro, Jorge Zahar Editor, 1994.

MASSON, J. F. (org.) Correspondência Completa de Sigmund Freud e Wilhelm Fliess 1887-1904. Rio de Janeiro, Imago, 1986.

MILLER, J.-A. Percurso de Lacan: Uma Introdução. Rio de Janeiro, Jorge Zahar Editor, 1997.

MILLOT, C. Freud Antipedagogo. Rio de Janeiro, Jorge Zahar Editor, 1995.

PIAGET, J. Psicologia e Pedagogia. Rio de Janeiro, Ed. Forence Universitária, 1998.

QUADROS, J. Curso Prático de Língua Portuguesa e sua Literatura - Estilística. Vol. IV, São Paulo, Editora Formar Ltda, 1966.

ROUSSEAU, J.-J. Emílio ou da Educação. São Paulo, Difel, 1968.

BRASIL. Secretaria de Educação Fundamental. Parâmetros Curriculares Nacionais: Ciências Naturais. Brasília, MEC/SEF, 1997.

.Parâmetros Curriculares Nacionais: Ter-

ceiro e Quarto Ciclos do Ensino Fundamental. Introdução aos Parâmetros Curriculares Nacionais. Brasília, MEC/SEF, 1998.

SOUZA, M.C.C.C. de. À Sombra do Fracasso Escolar: A Psicologia e as Práticas Pedagógicas. In Estilos da Clínica: Revista sobre a Infância com Problemas. São Paulo, Instituto de Psicologia da USP, Pré-Escola Terapêutica Lugar de Vida, ano 3, número 5, 1998.

STRYCHMAN, N. Historicidade do Conceito de Transferência. In Dicionário de Psicanálise: Freud \& Lacan. Salvador, Ágalma, 1994, pp. 259-285.

WILLEMART, P. Psicanálise e Pedagogia ou Transmissão e Formação. In Revista USP. São Paulo, número 31, pp. 201-209, setembro/novembro 1996. 